\title{
Late Quaternary fluvial stratigraphy of the St. Albans archeologic site (46KA27), West Virginia
}

\author{
Courtney Andreas Nugent \\ West Virginia University
}

Follow this and additional works at: https://researchrepository.wvu.edu/etd

\section{Recommended Citation}

Nugent, Courtney Andreas, "Late Quaternary fluvial stratigraphy of the St. Albans archeologic site (46KA27), West Virginia" (1998). Graduate Theses, Dissertations, and Problem Reports. 926.

https://researchrepository.wvu.edu/etd/926

This Thesis is protected by copyright and/or related rights. It has been brought to you by the The Research Repository @ WVU with permission from the rights-holder(s). You are free to use this Thesis in any way that is permitted by the copyright and related rights legislation that applies to your use. For other uses you must obtain permission from the rights-holder(s) directly, unless additional rights are indicated by a Creative Commons license in the record and/ or on the work itself. This Thesis has been accepted for inclusion in WVU Graduate Theses, Dissertations, and Problem Reports collection by an authorized administrator of The Research Repository @ WVU. For more information, please contact researchrepository@mail.wvu.edu. 


\section{Late Quaternary Fluvial Stratigraphy of the St. Albans Archeologic Site (46KA27), West Virginia}

Thesis

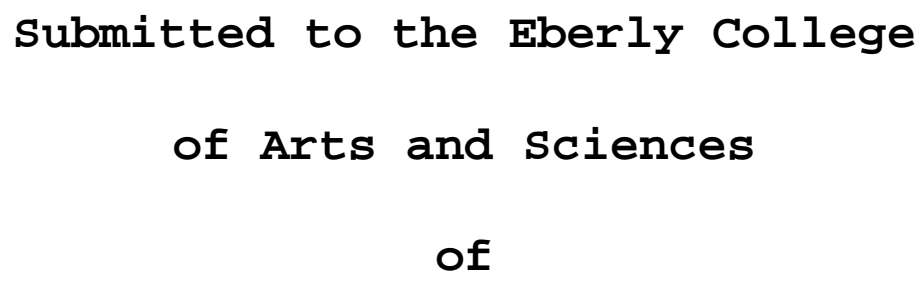

in partial fulfillment of the requirements for the Degree of Master of Science in Geology

by

Courtney A. Nugent

Morgantown

West Virginia 


\section{Abstract \\ Late Quaternary Fluvial Stratigraphy of the St. Albans Archeologic Site (46KA27), West Virgina}

The st. Albans archeologic site, West Virginia(46KA27), occurs on a low terrace of the Kanawha River. Archeologic investigations have been conducted at the site since 1964 . Geologic investigation techniques have included core drilling, sediment texture analyses and magnetic susceptibility analyses. Data from these analyses have provided a better understanding of the stratigraphy, magnetic susceptibility and artifact distribution at the site and has lead to the development of a model that predicts the potential for recovery of cultural resources. The model should help planning future excavations at the site.

The geomorphology of the Kanawha River valley at St. Albans is related to the geologic history of the Ohio River valley. Late Pleistocene glaciation brought excess sediments into the Ohio River causing aggradation. Later, much of this sediment was transported down the Ohio River during an incision event. These Ohio River events were responsible for altering Kanawha River baselevel, causing a complex response that may be the principal mechanism for the aggradation and subsequent degradation of both a late Wisconsin terrace (610 ft elevation) and the younger st. 
Albans terrace (590 ft elevation).

Most of the St. Albans terrace is a landform that apparently began to aggrade before 12,900 B.P.. The St. Albans Archeologic Site is located on a newer landform that consists of a $8.9 \mathrm{~m}$ overbank facies overlying a $7.8 \mathrm{~m}$ channel-sand facies. Radiocarbon dates indicate overbank facies sedimentation began between 9,900 B.P. and 13,750 B.P., with typical floodplain sedimentation rates suggesting a time closer to 9,900 B.P.. The channel facies should be archeologically sterile.

Charcoal fragments, reddened soils and fire-cracked rocks indicate that most high magnetic susceptibility readings are produced by fire. The association of artifacts in many of these high magnetically susceptible sediments indicates they are cultural fire hearths. High susceptibilities can also be related to forest fire, pedogenesis, and fermentation of organic wastes. The later two of which can also be indicators of buried occupational surfaces. When executed early in an archeological study, magnetic susceptibilities profiles on cores should aid in locating more productive excavations. 


\section{Table of Contents}

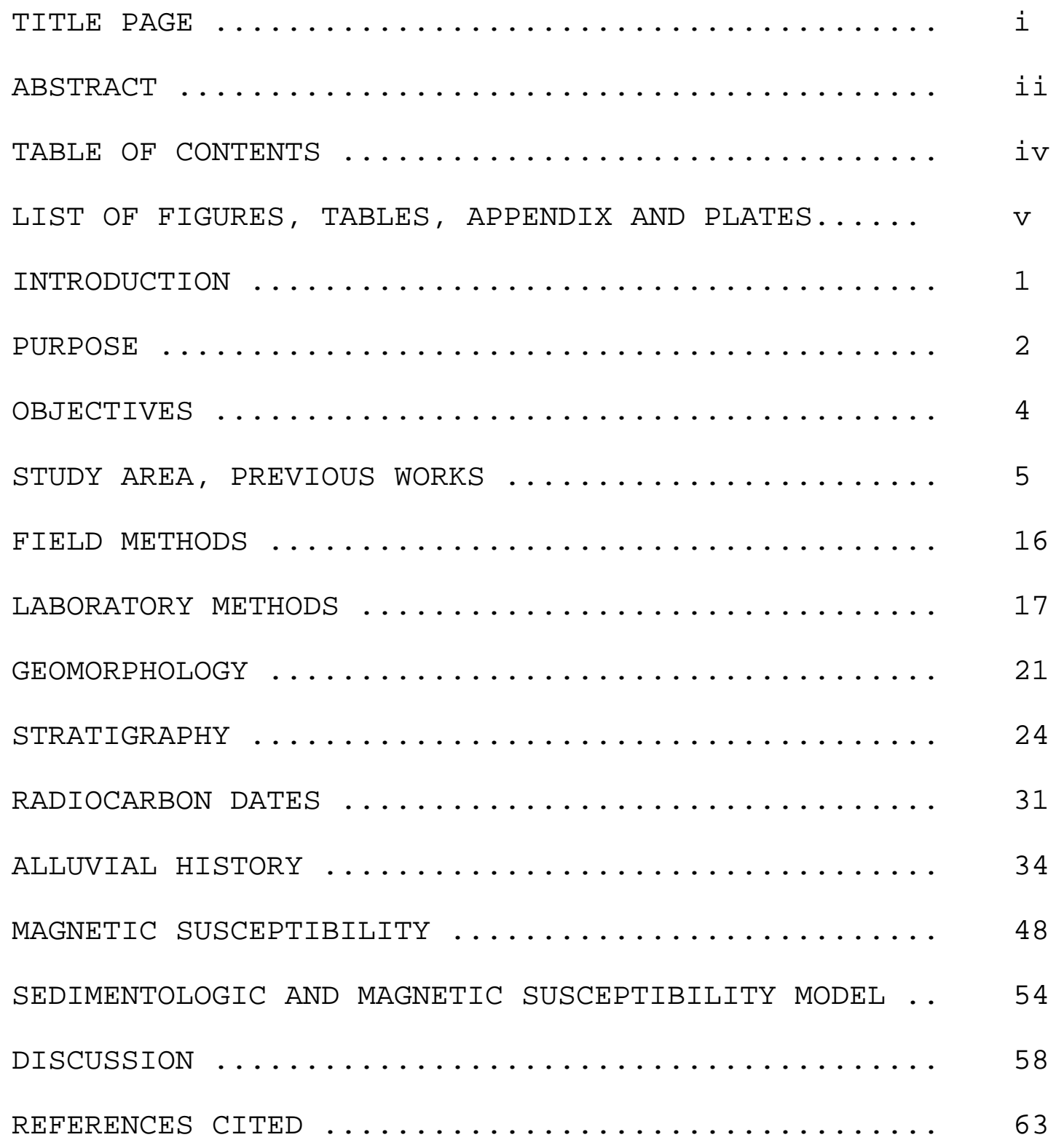




\section{List of Figures, Tables,}

\section{Appendix and Plates}

1 Map showing the location of St. Albans and Galipolis 6

2 Broyles's excavation showing upper stratigraphy of levee 9

3 Barlow's map of site and island $\quad 11$

4 Rogers's cross-section of surfaces 2 and $3 \quad 13$

5 U.S.D.A. textural classification ternary plot 20

6 Map of ancient Teays drainage system 22

7 Topographic map of St. Albans vicinity 23

8 Broyles's excavation showing cut-and fill 28

9 Alluvial history of Kanawha valley at st. Albans 39

10 Possible channel migration 41

\section{TABLE}

1 Radiocarbon dates from St. Albans 32

2 Summary of geologic history of St. Albans and Wisconsin terraces

\section{APPENDIX}

1 Textural analyses data

\section{PLATES}

A Cross-section of site with magnetic susceptibility (from cores)

End of document

B Map of site showing core and riverbank profile locations 


\section{INTRODUCTION}

Communities commonly developed adjacent to life-sustaining water bodies. Given this tendency, most archeological sites in the Eastern United States occur along floodplains and terraces of waterways. The St. Albans archeological site (46KA27), located on a terrace adjacent to the Kanawha River, serves as an archetype to geoarcheologic investigations of deep stratified site's. In addition to conventional archeological investigative techniques, sediment texture and magnetic susceptibility analyses have been applied to cores taken from and profiles cut into the sites strata. Supplemented by radiocarbon dates and archeological data from previous investigations, the textural and magnetic susceptibility analyses have provided a four dimensional (northsouth, east-west, depth and time) view of the site. A clear understanding of the stratigraphy, magnetic susceptibility and artifact distributions has great potential to enhance future archeological excavations at the site.

In addition to providing archaeological insights, the investigation at St. Albans has provided a regional perspective on the geomorphic development of the Appalachian Plateaus during the Pleistocene. Pleistocene glaciation scoured northern landscapes and transported much sediment into the Appalachian Plateau north of the study area, postglacial fluvial processes have further transported much of these glacial deposits 
downstream. During the Late Pleistocene, the quantity of these deposits exceeded the competence of the Ohio River system, resulting in an aggradational event that raised base-level for its tributaries. After the influx of extra-basin glacial deposits decreased, the Ohio River system began to erode into the stored valley deposits, initiating an incision event that lowered baselevel for the tributaries. These base-level adjustments had a strong influence on the development of the lower Kanawha River terraces.

\section{PURPOSE}

The St. Albans Archeological site, first excavated in the 1960's, is located on a low terrace of the Kanawha River. Archeologists have discovered occupational zones within these deposits to a depth of $24 \mathrm{ft}$ (Broyles, 1971). The exceptional depth and complex fluvial stratigraphy of the site warrant further geological investigation. The aim of the investigation is to acquire data from the site that will lead to the development of a geoarcheological model. This model will allow prediction of the potential for recovery of cultural resources so that the most productive excavation locations within the site can be predicted. This model will be important to planning future excavations at the study area and similar sites within the Kanawha River Valley. This project, in conjunction with past and future studies, 
will add pieces to a much larger puzzle: the Quaternary fluvial history of the Appalachian Plateaus. In addition to the model, the second purpose of the study is to explore base-level adjustment as possibly the principal control over the development of the St. Albans site terrace, thereby documenting a fluvial mechanism that should be found as a similar control on the development of terraces of other nearby tributaries to the Ohio River. This fluvial mechanism may be extended to help explain the development and incision of aggradational terraces in many glacially influenced drainage basins in the Appalachian Plateaus. 


\section{OBJECTIVES}

The objectives of this project are based on two separate and distinct sets of expectations:

\section{Geoarcheology}

1. To describe in detail the stratigraphy of the st. Albans archeological site and to construct cross-sections using continuous split-spoon samples from test borings.

2. Describe and trace high magnetic susceptible horizons both vertically and horizontally; determine the applicability of magnetic susceptibility meters in delineating potential occupational zones

3. Develop a stratigraphic model for the prediction of productive archeological excavations within the site.

\section{Quaternary Geology}

1. Establish an alluvial chronology for the site including sedimentation rates.

2. Construct a general late Quaternary paleoenvironmental interpretation for the Kanawha River. The interpretation will focus on the following: channel aggradation vs. degradation, river-bank stability, channel morphology, etc.

3. Look for patterns in the paleoenvironmental interpretations for the Kanawha that reflect glacial meltwater influences upon the Ohio River. 


\section{STUDY AREA}

The St. Albans site is located on a low terrace of the Kanawha River in St. Albans, West Virginia. The site is approximately $24 \mathrm{~km}$ (15 $\mathrm{mi}$ ) west of the state capitol, Charleston, and $65 \mathrm{~km}$ (40 mi) upstream from the Kanawha RiverOhio River junction (Fig. 1). The upper surface at the site was last inundated during the record historic flood, 29 september 1861 (Doll and others, 1960).

The terrace had an average elevation of about $590 \mathrm{ft}$, or about 45 ft above the normal high water level before construction of U.S. Route 60 and the Winfield Lock Dam (Barlow, 1971). The terrace surface has been lowered by as much as $6 \mathrm{ft}$ from the construction of Route 60 and the normal pool water level is now $20 \mathrm{ft}$ higher than the normal high water level due to the dam construction (Barlow, 1971).

\section{PREVIOUS WORKS}

The first study at the St. Albans Archeological Site (Price and others, 1964) tested the applicability of core drilling at archeological sites in alluvial valleys. Aside from providing sediment samples useful for stratigraphic interpretations, the core drilling provided insight to the location of successful excavations. Core samples containing charcoal, burned earth or artifacts were assumed to be more indicative of past human 


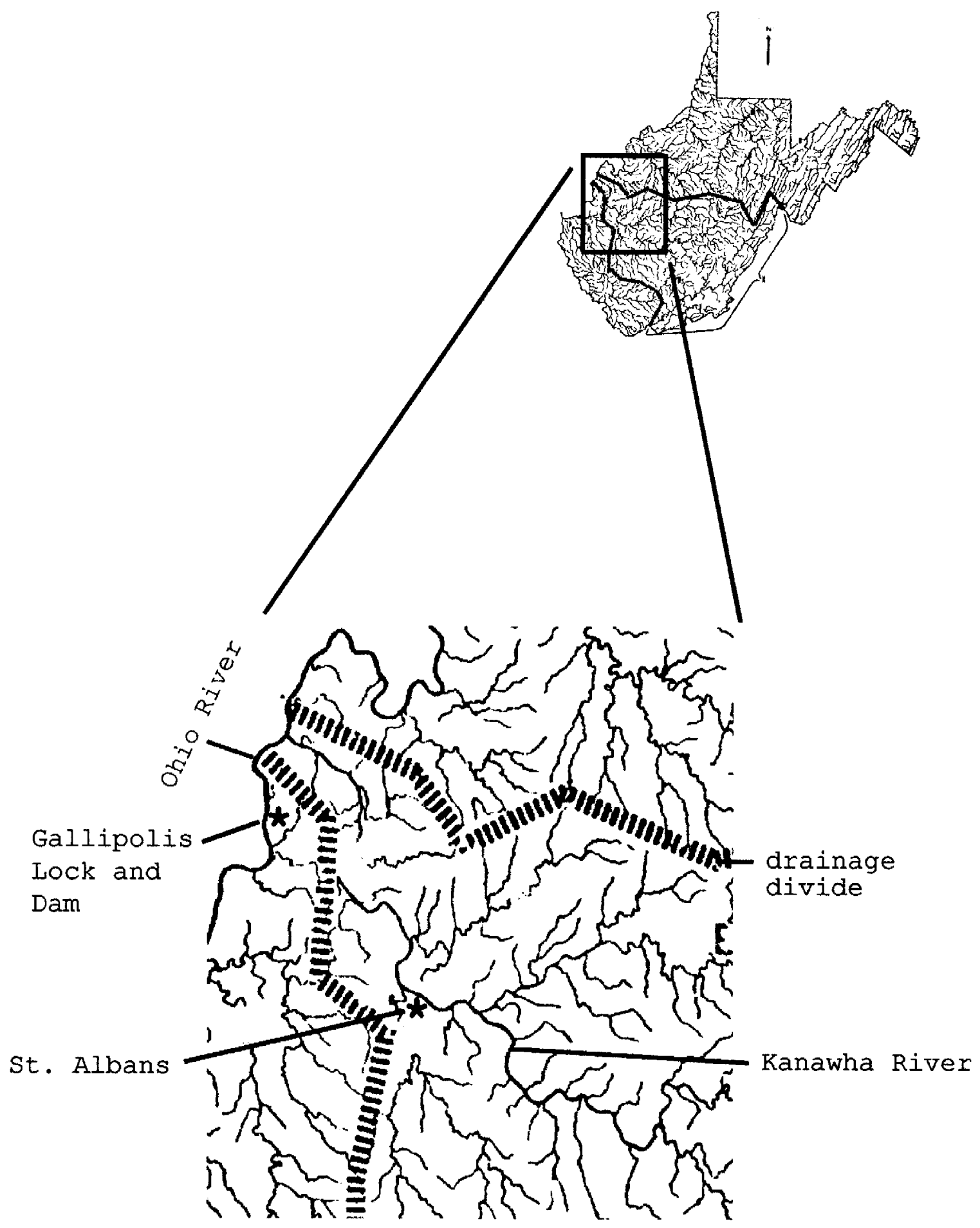

Figurel. Map Showing the locations of St. Albans and Gallipolis study sites (After Broyles, 1971) 
occupation than cores absent of these materials. Of six cores taken in a $91 \mathrm{~m}$ by $23 \mathrm{~m}$ area, the two or three cores most indicative of human occupation were assumed to delineate the lateral extent of the site. However, this assumption was only partially accurate. Although the cores did help to delineate a focus of past human occupation, this was only one of many locations of past human occupation at the site. The site, as it is known today (Anslinger, 1998), occupies a greater expanse of the terrace than was interpreted by Price and others (1964). Nevertheless, their study demonstrated core drilling to be a practical and relatively noninvasive first step to help in the decision of where to locate excavations. The most successful of all excavations at the site was located in the area of the three cores most indicative of human occupation.

Price and others (1964) proposed the site to have been an island. Their interpretation stemmed from the presence of a bluegrey clay found in the most upstream core and a peat-like material found in a core taken $23 \mathrm{~m}$ south of the river. Price and others, interpreted the blue-grey clay to represent quiet water sediments, and the peat-like material to have formed in a slough or oxbow between the island and mainland. A full explanation of how these two findings supported their island hypothesis was not provided.

Broyles (1971) summarizes methods and results of four 
summers of archeological work at the site, including important descriptions and diagrams of site stratigraphy. From Broyles's work came many period-specific artifacts and radiocarbon dates to aid in developing an alluvial and cultural chronology for the St. Albans terrace. Broyles's excavations showed upper strata that gently sloped away from the river (Fig. 2). From these observations Broyles interpreted the site to have been on a levee.

Olafson (1971) summarized the possible influence that late Pleistocene climates had on the development of the site. Although Olafson stated that the type of floodplain aggradation that formed the St. Albans terrace is common in streams in the glaciated regions, he disclaimed the possibility of a similar development for the St. Albans terrace due to lack of glacial meltwater in the Kanawha basin. Instead, Olafson described the glacial history of regions north of the study area and proposed climatic changes for the study area in response to events to the north. Rates of aggradation or incision for the St. Albans terrace were inferred from the proposed climactic changes. Barlow (1971), expanded on Olafson's work by coupling the same climatic controls with stratigraphic observations to speculate on specific sedimentation and erosion events and the topography of the site. Barlow (1971, in Table 3), referenced Schumm's work (1965): Quaternary fluvial processes as controlled 


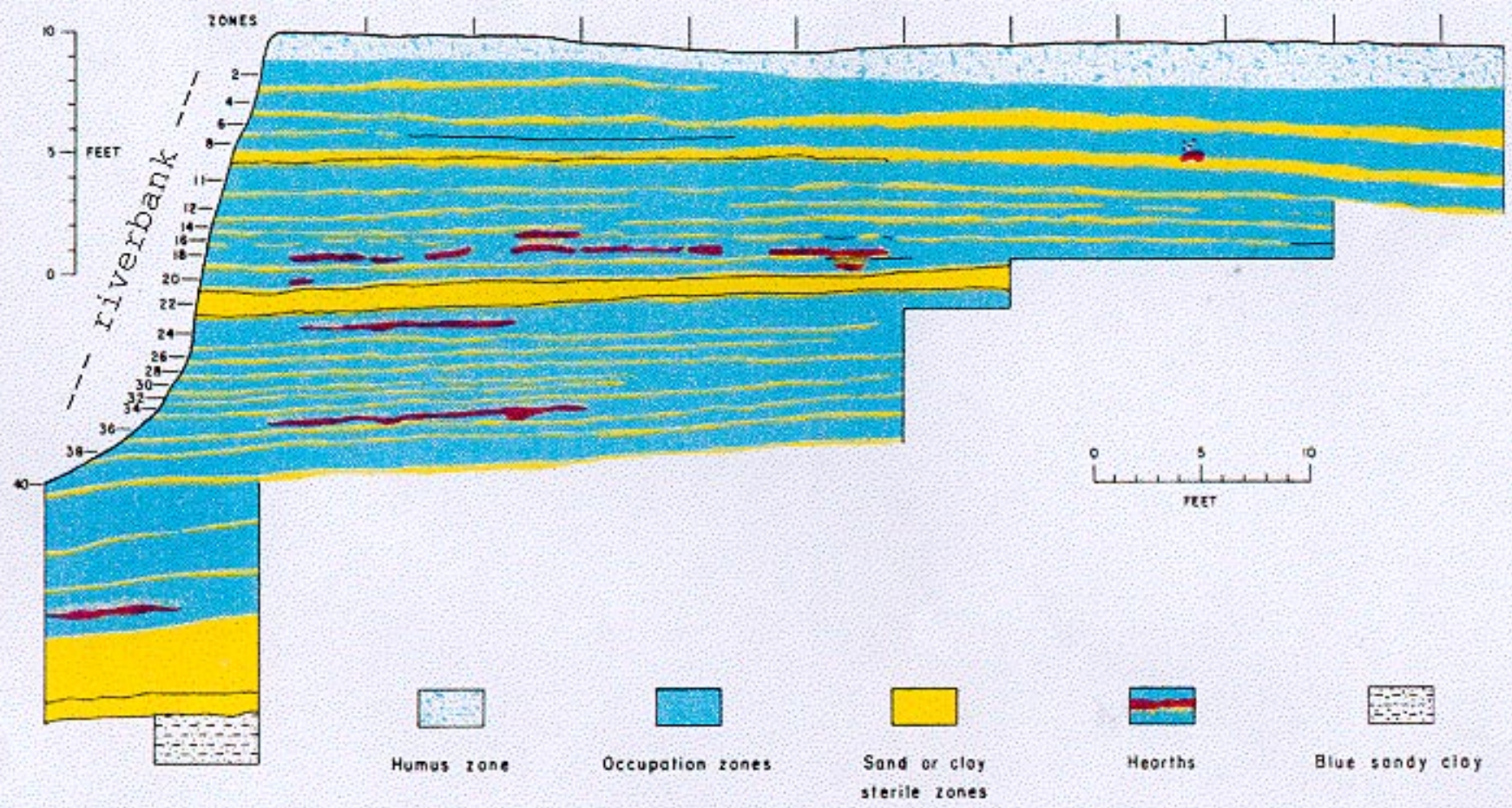

Figure 2. Broyles's excavation showing upper stratigraphy of a levee (After Broyles, 1971). Note: None of the cores in this study are a part of this cross-section. 
by climatic fluctuations, to partially support his interpretations.

Barlow matched radiocarbon dates with stratigraphic

intervals to calculate discrete rates of sediment accumulation or erosion to further support the proposed aggradation and erosion events. In turn, these proposed aggradation and erosion events were matched to regional glacial retreats or advances respectively, thereby suggesting glacial influence on local climate as the principal control on the geomorphic development of the site.

Because the site stands above its immediate surroundings, Barlow (1971) also interpreted the site to have been an island. He interpreted the depression that separates the site from the valley wall as a remnant bifurcation of the Kanawha that he termed "old south channel," (Fig.3). Barlow stated that, in order for the ancient peoples to have continually reoccupied the site for thousands of years, the site would have to be a distinguishable feature of the landscape, such as an island. The studies of Hand and others (1988) at Winfield Lock and Dam, West Virginia and Mandel (1988) at Gallipolis Lock and Dam, West Virginia, are similar to this study. Both of these studies use geomorphologic interpretations to predict zones of high and low cultural resources recovery potential. These studies also suggest the Ohio River to have a strong base-level influence on 


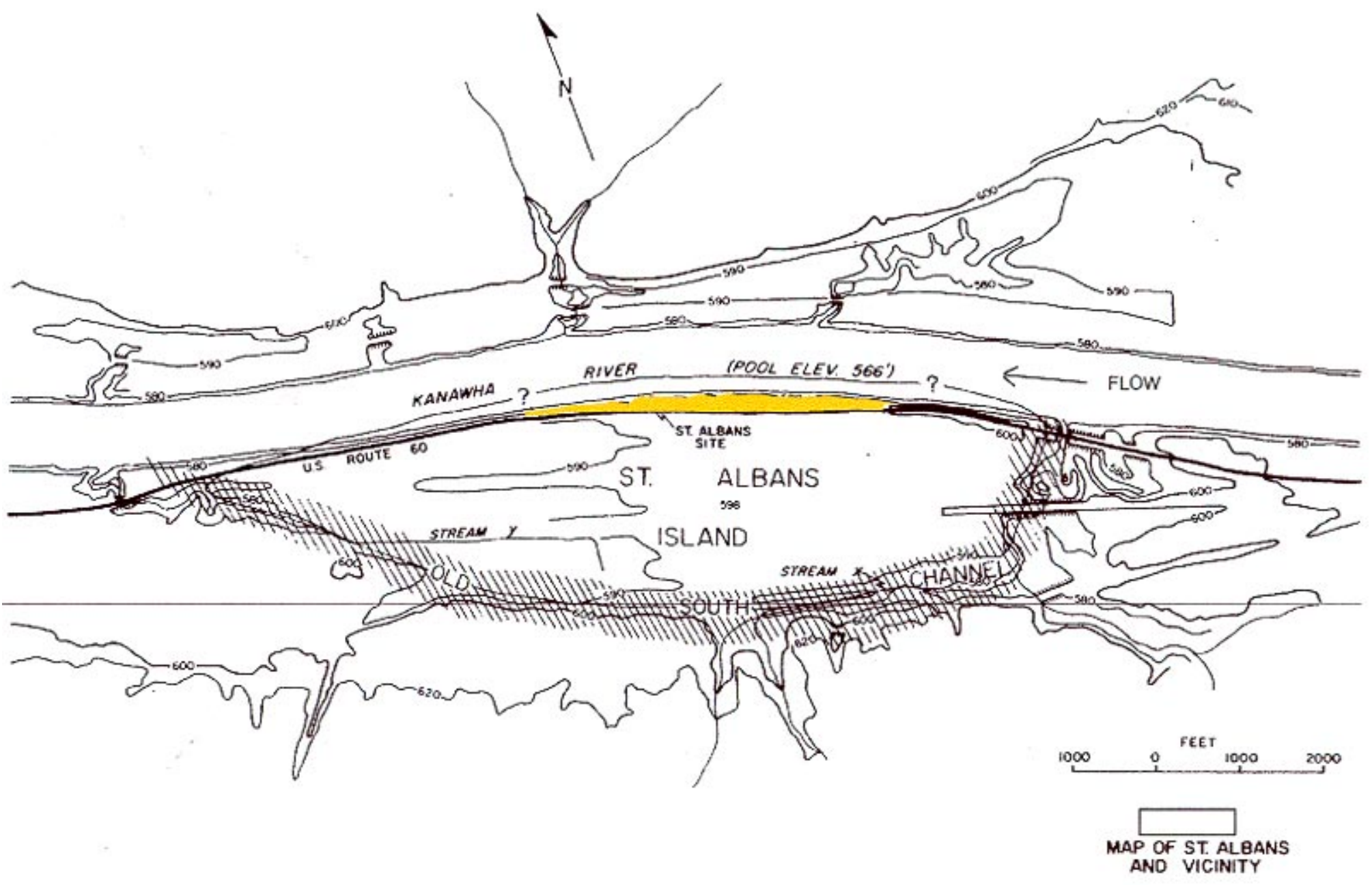

Figure 3. A map showing the archeologic site and Barlow's proposed island with "old south channel" (After Barlow, 1971). 
the alluvial development of the Kanawha River during the Quaternary

Rogers and others (1989), Rogers (1990), and Kite and others (1990) research at the Gallipolis Lock and Dam replacement project (Fig. 1) was based on over 200 exploratory borings into two low terraces of the upper Ohio River (surfaces S2 and S3; Fig. 4) and an excavation of a canal into the lower of these terraces (S2). Sediments just above the bedrock base of these two surfaces were deposited around 22,000 yr. B.P., and $27 \mathrm{~m}$ of sedimentation occurred on this base between 22,000 and >13,000 yr B.P. to produce surface S3. Sand unit B1, deposited near the beginning of $\mathrm{S} 3$ sedimentation, has sedimentary structures indicative of braided channel origin. Boulder horizons beneath S3 show evidence of two possible large paleofloods with discharges more than ten times greater than the maximum historic flood at Gallipolis. Between $<21,000$ and 13.000 yr B.P. surface S3 was incised $21 \mathrm{~m}$ to produce a major unconformity about $3.5 \mathrm{~m}$ to $4 \mathrm{~m}$ above bedrock. Between 13,000 yr B.P. and the present, about $15 \mathrm{~m}$ of sedimentation occurred on this unconformity to produce surface S2. Sand unit B2, deposited just above the unconformity, also has sedimentary structures indicative of braided origin.

The large-scale nature of the excavations involved in the studies at Gallipolis expose a thorough view of the Quaternary alluvium. This alluvium is also well radiocarbon dated. The 


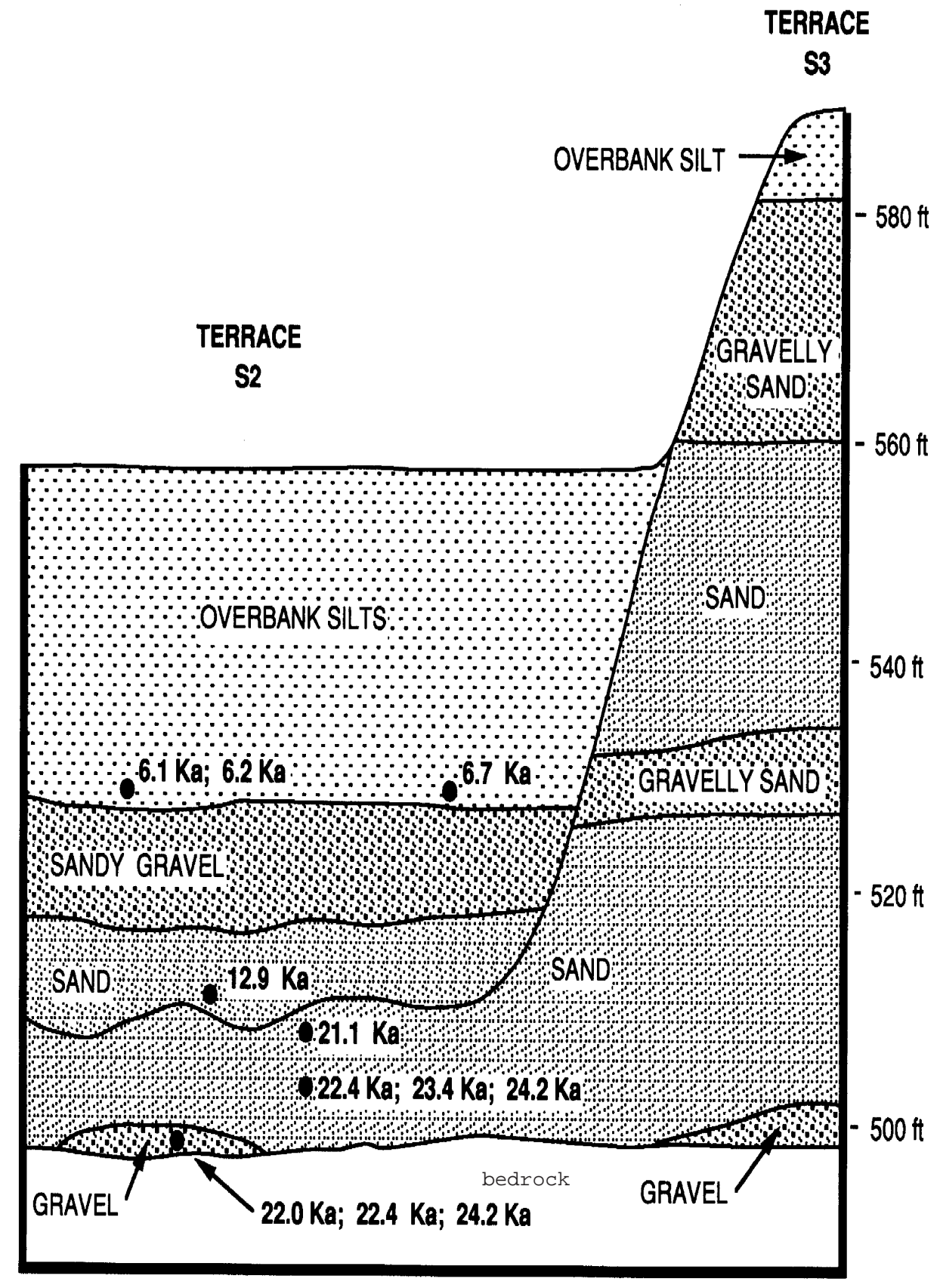

Figure 4. Roger's cross-section of surfaces 2 and 3 with radiocarbon dates at the Gallipolis Lock and Dam study site (After Rogers, 1990). 
information from Gallipolis is a valuable resource to this study because the findings of these studies directly support much of the alluvial history interpreted in this study. The age and geometry of surfaces S2 and S3 at Gallipolis are similar to the St. Albans and Wisconsin terraces in this study. Therefore, two correlations are suggested: The first between surface $\mathrm{S} 2$ and the St. Albans terrace, and second, between surface s3 and the Wisconsin terrace. Magnetic resistivity studies employed at the site displayed nothing but a gradual increase in conductivity with depth. Clay (personal communication, 1993) suggests that this occurrence is probably the influence of the water table. A Geonics GN38 surface magnetic susceptibility meter was also tested at the site with no success.

Magnetic susceptibility attenuates in very short distances, so surface magnetic susceptibility surveys are not likely to delineate anomalies below $0.5 \mathrm{~m}$ depth (Kite and others, 1993). Surface magnetometers have less signal attenuation with depth, however, and are poor at delineating broad features with illdefined margins such as those generated by buried soil horizons, fire hearths, or sedimentary layers (Kite and others, 1993). Therefore, it appears that the hand-held magnetic susceptibility meter is a highly suitable geophysical instrument for the aid in developing deeply-stratified archeological sites. The meter appears to have potential as a stratigraphic correlation tool and 
for delineating potential occupation zones.

Personnel from Cultural Resource Analysts, Inc. monitored two bank-stabilization projects for the Huntington District Corps between 1994 and 1996 (Anslinger, 1998). These projects occurred in or partially within the existing National Register boundaries for the site. Sections of the river bank were studied to document stratigraphic relationships between sediment units, soils and archeological inclusions during the project. River bank profiles in the upstream reaches of this study displayed sediments and archeology similar to previous studies by Broyles (1971) and Brashler (1994). However, further downriver, profiles revealed massive, fine grained sediments with little discrete strata that contained far fewer artifacts. Anslinger (1998) interpreted these sediments to represent a lower energy depositional environment located behind a levee that has since been eroded and is no longer present. A sample that dated to 12,910 +/- 60 B.P. (Beta 102187) came from a depth of $4.8 \mathrm{~m}$ (Anslinger, 1998). This date is roughly three thousand years earlier than dates obtained at comparable depth at the archeologic site. This age discrepancy suggests the presence of two landforms and will be explained in more detail in the alluvial history section. 


\section{FIELD METHODS}

The H.C. Nutting Company made 12 test borings using a CME-55 rig with an automatic hammer. Continuous split-spoon samples were taken the entire length of the borings; however, portions of some sediment samples were lost down the bore holes. Seven of the test borings were made with a 2-inch diameter spilt-spoon sampler, with about 90 percent sediment recovery. Five borings were made with a 3-inch diameter split-spoon sampler, with more than 75 percent recovery. All of the split-spoon samples were stored in the West Virginia University Quaternary Geology Lab after being sealed in 2-foot sections of split PVC pipe. Plate B shows the core drilling locations.

Magnetic susceptibility measurements were taken on vertical profiles at the site. These profiles were cut into the river bank face with shovels and then scraped clean with trowels to prepare smooth surfaces for consistent magnetic susceptibility measurements. A fiberglass metric tape measure was hung down the vertical face and magnetic susceptibility measurements were taken at 2-cm intervals down the profile. The standard procedure was to take two magnetic susceptibility measurements at each interval, however, if the second magnetic susceptibility measurement was not within 10 percent of the value of the first magnetic susceptibility measurements, three or more readings were taken until the last reading fell within 10 percent of the previous 
measurement. The averages of these readings were reported for each of the 2-cm intervals. Brief sediment descriptions were also recorded during magnetic susceptibility measuring.

\section{LABORATORY METHODS}

Magnetic susceptibility measurements were made on the 12 split-spoon sediment samples. The procedures were essentially the same as those used to take magnetic susceptibility measurements in the field, except that care was taken not to allow metallic laboratory objects to influence the meter. Experimentation showed interference from metallic objects declined to unmeasurable levels beyond one foot distance. For security, a distance of two feet from metallic objects was maintained during measurement. The split-spoon samples acquired in this study displayed considerable distortion. Cohesive sediments induce friction upon the inner surface of the split-spoon as it is driven down. This friction causes the outer portions of the sample to be dragged downward with the penetrating split-spoon. Coarse sediments, do not adhere well to the inner split-spoon surface due to lack of cohesion and tend to fall out of the sampler when brought up to the surface. The water table at St. Albans is located near the transition between the overlying fine-grained overbank sediments and the lower coarse-grained channel sands. Fine-grained overbank sediments occur above the water table where there is little water 
to reduce the friction that causes the drag type of distortion. Coarse-grained channel sands occur below the water table, where slipping may be enhanced by the presence of water.

If sediment in a particular 2-foot section had been compressed during sampling, all magnetic susceptibility measurement intervals taken from that particular section were recalculated so as to expand the retained sample to fill the entire 2-foot section. For example, if a two-foot section was 20 percent shortened, the measurements that initially were taken at $2 \mathrm{~cm}$ intervals were recalculated to represent $2.4 \mathrm{~cm}$ intervals. If sample stretching occurred during sample retrieval, the reverse procedure was taken so as to shrink the sample down to a two-foot section. For example, if a two-foot section was 5 percent stretched, the initial $2 \mathrm{~cm}$ intervals were recalculated to represent $1.9 \mathrm{~cm}$ intervals. In these examples, an adjustment was made in each case so that the sample is represented in its original dimension prior to distortion.

Textural analyses were conducted on sediment samples from the 12 test borings and vertical profiles in the field. Most of the dry-sieve and pipette methodology of the textural analyses came directly from Bell (1986), however, minor adjustments were made in the sequence of screens used in the dry-sieve methods. Essentially, the screens with larger mesh openings were omitted due to the fine texture of the sediments in this study. The 
sampling interval for textural analyses was based on textural estimations. Textural estimations were made after observing the following properties: appearance, tactile properties, plasticity of rolled threads and friability of dry samples. The textural estimations were used to assign textures to the sediments. These examinations lead to the recognition of many different textural changes in each core and bank profile. All the cores and bank profiles displayed fluctuating trends in sediment texture for the length of the core or profile. Textural estimations revealed too many textural changes for each of those changes to be tested by textural analysis. Textural analysis samples were taken at the peak of each rising trend in sediment coarseness and trough of each falling trend in sediment coarseness for each core or profile. Results of textural estimations and textural analyses were described according to USDA soil texture classification (Fig. 5) based on percent sand, silt, and clay (Soil survey Division Staff, 1993).

Stratigraphic columns were generated from textural classifications with the use of the graphic software program Adobe Illustrator 88 and 7.0 on a personal computer. The same procedure that was used to recalculate magnetic susceptibility measurement intervals in their original dimensions, were used in generating stratigraphic columns. 


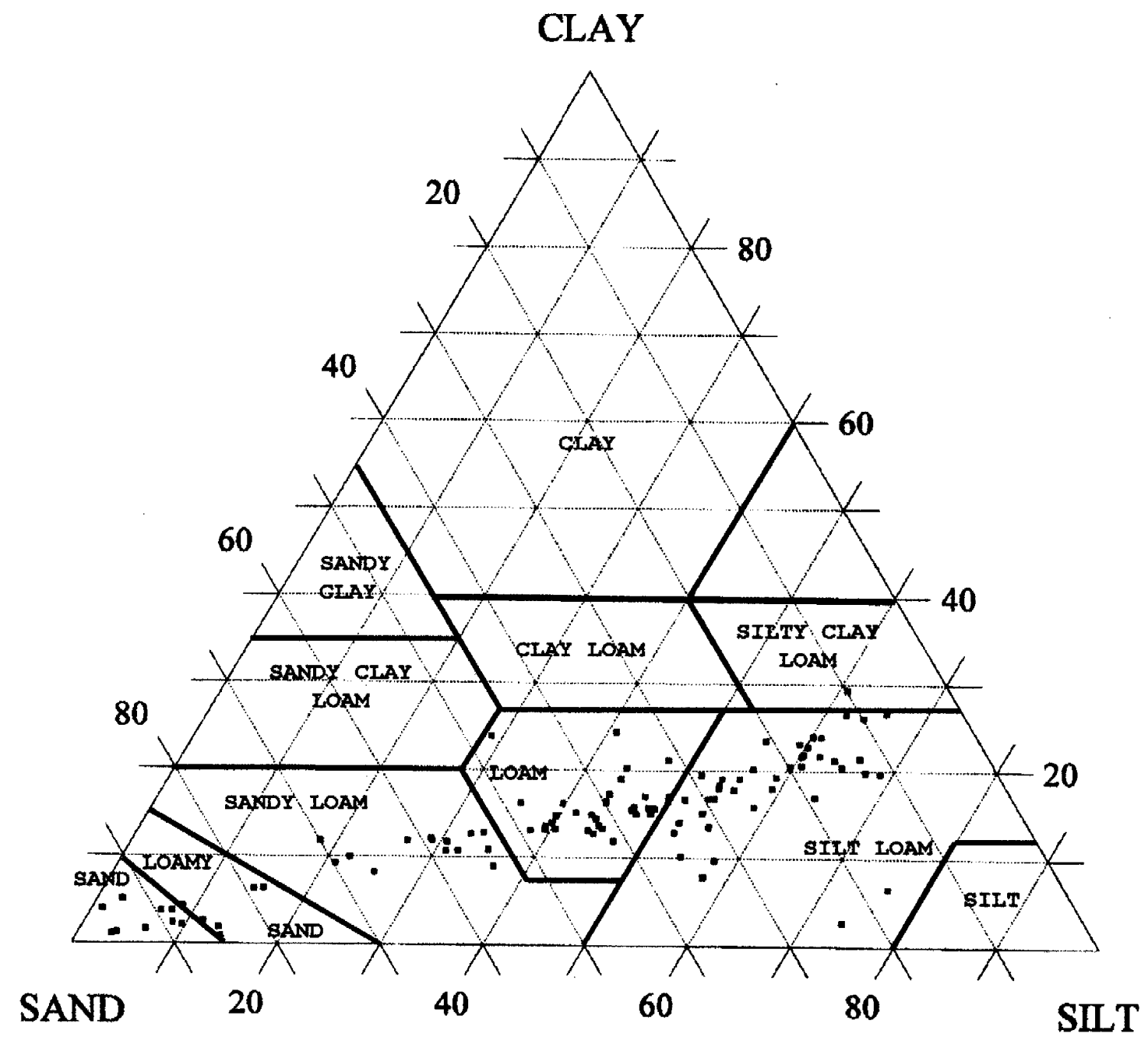

Figure 5. U.S.D.A. textural classification ternary plot (Soil Survey Division Staff, 1993) showing results of St. Albans textural analyses; particles greater than $2.0 \mathrm{~mm}$ not represented. 


\section{GEOMORPHOLOGY}

The Kanawha River valley in the vicinity of St. Albans has about 500 ft of relief between the normal pool elevation at 566 ft and the surrounding highlands. A terrace that is a remnant of the Teays River exists on the south valley wall between $660 \mathrm{ft}$ and 700 ft elevation. The Teays River (Fig. 6) headwaters were near Blowing Rock, North Carolina, and the river flowed along the course of the present New and Kanawha rivers upstream from the site (Hansen, 1998). Just downstream from St. Albans, at the location of Scary, the Teays River course departs from the Kanawha River valley and tracks westward into Ohio (Kite, 1992; Hansen, 1998). Between 0.79 and $0.88 \mathrm{~m} \cdot \mathrm{y} \cdot$ ago, glacial advancesblocked the Teays drainage system near Chillicothe, Ohio forming Lake Tight (Bonnett and others, 1991). Lake Tight extended from this glacial dam southeastward to near Hawk's Nest, West Virginia (Bonnett and others, 1991). Eventually the lake waters were pirated, initiating a drainage modification that marked the beginning of the development of the upper Ohio River system (Bonnett and others, 1991).

The remnants of a younger, paired terrace exist at an elevation of about $610 \mathrm{ft}$. The remnants of this terrace are conveniently outlined by the $600 \mathrm{ft}$ topographic contour in areas outlying the archeologic site (Fig. 7). Although this terrace is paired, it has been eroded completely along one or both sides of 


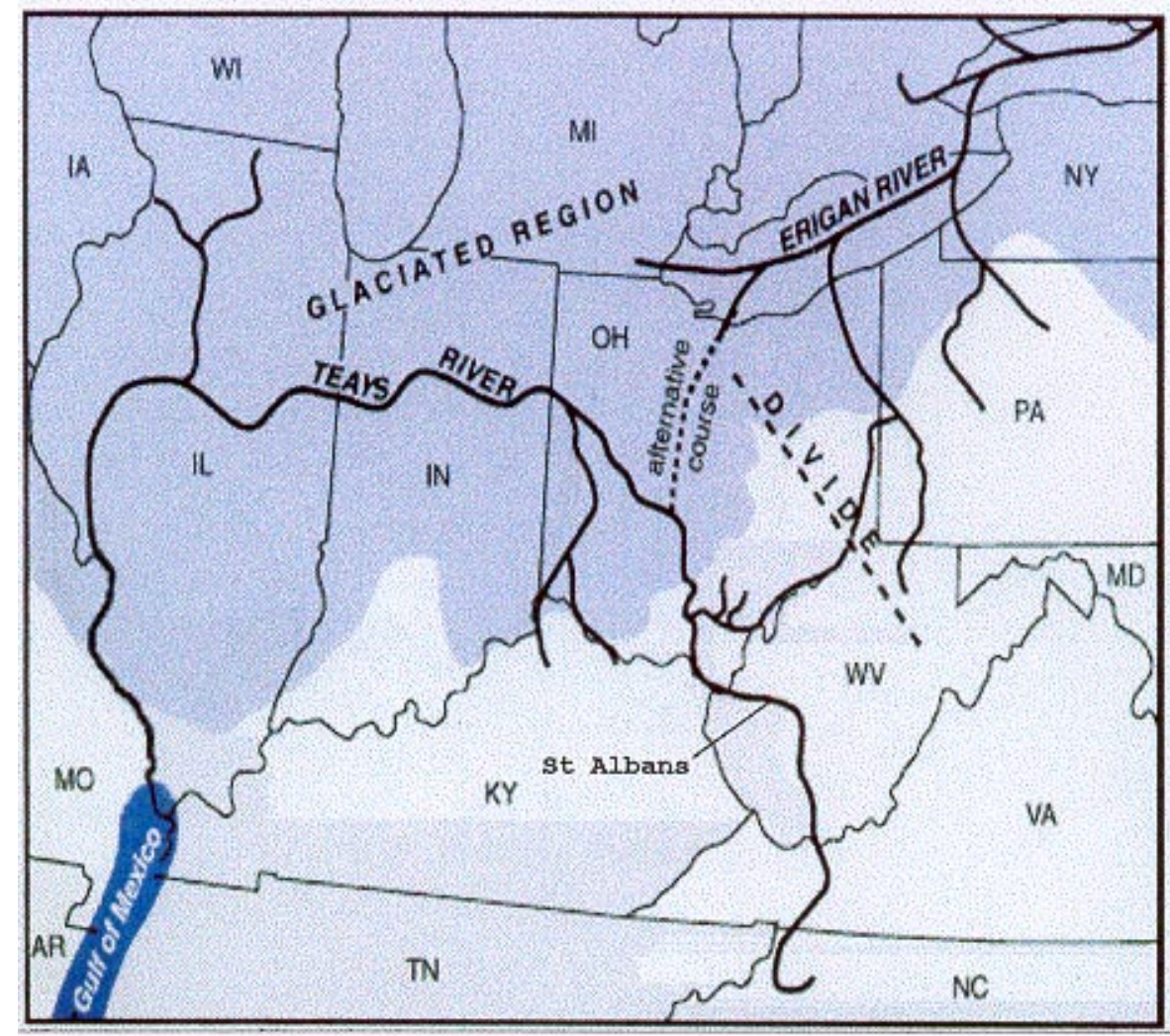

Figure 6. Map of the ancient Teays drainage system (from Hansen, 1998). 


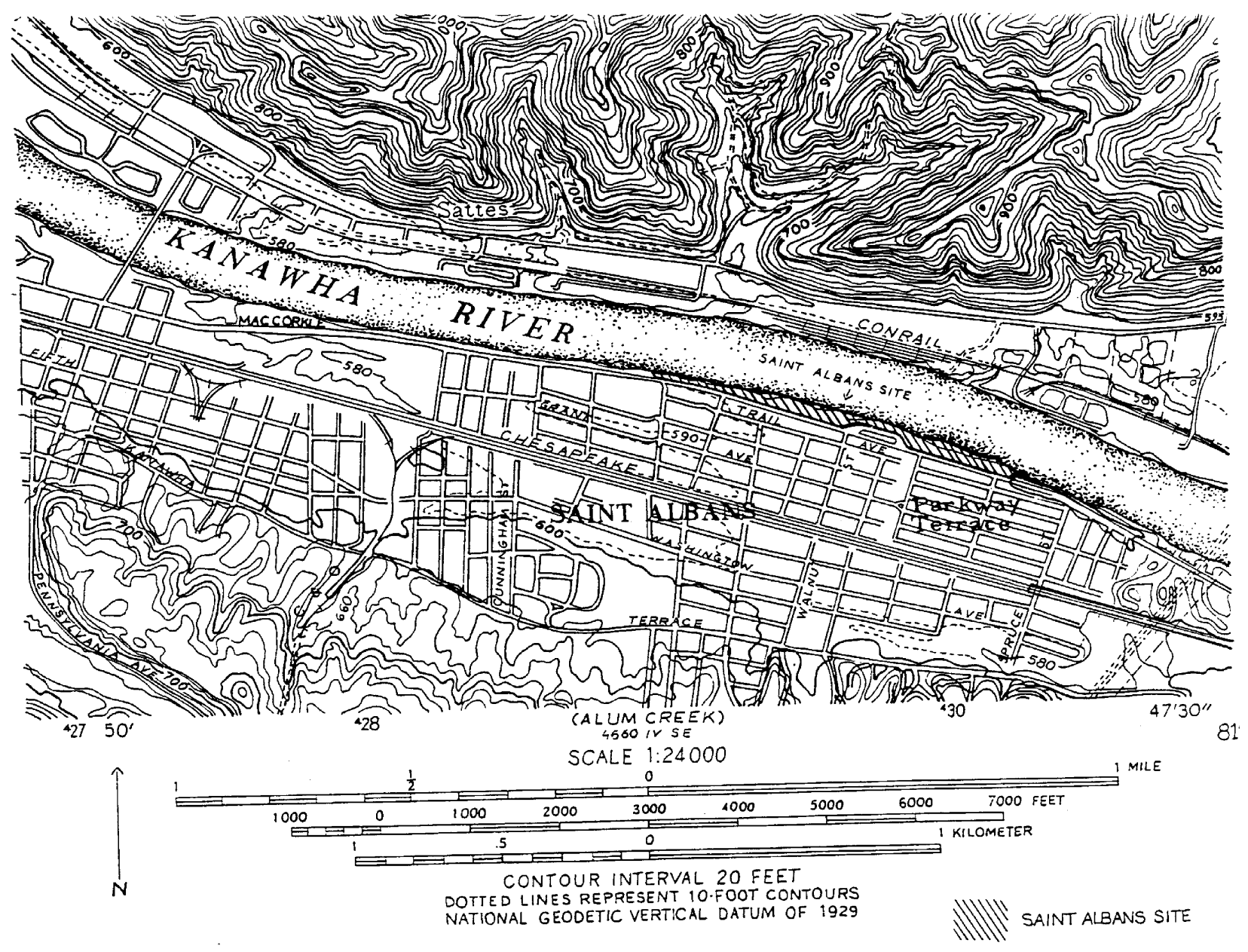

Figure 7. Topographic map of St. Albans vicinity; $600 \mathrm{ft}$ contour outlines Wisconsin terrace (After Brashler, 1994). 
the valley in many reaches of the valley. This terrace has been interpreted as Wisconsin in age (Kite, 1992).

The St. Albans terrace is located in an alluvial valley bottom that ranges from 1.0 to $1.5 \mathrm{~km}(0.7$ to $1.0 \mathrm{mi})$ in width. The St. Albans terrace occupies most of the valley bottom except for the Wisconsin terrace, which is only about twenty feet higher. The width of the terrace is about $0.7 \mathrm{~km}$ on the south side of the river and about $0.3 \mathrm{~km}$ on the north side of the river. About $150 \mathrm{~m}$ to $275 \mathrm{~m}$ inland from the present south river bank is an elongated ridge that may be an inland remnant of a previous levee. This elongated ridge may represent the channel margin when the Kanawha River channel was located more to the south.

\section{STRATIGRAPHY}

Sediments retrieved by split-spoon methods do not yield a distinct view of individual beds due to either bioturbation, distortion during sampling and lack of lateral exposure. Upon first appearance, the sediments in the cores looked rather homogeneous for most of their length. However, textural descriptions of the cores, confirmed by grain-size analyses, allowed breaking out more stratigraphic units than appeared during initial visual examination. The description by texture, however, may have lead to some over-generalization of the 
stratigraphy by representing sediments of separate beds as the same bed because they fell into the same USDA textural classification. This over-generalization is believed to be rare because the sampling strategy was oriented so that adjacent samples would come from sediments contrasting in texture. Stratigraphic division may have occurred if grain size analyses yielded different textures for samples taken from distant portions of a single, thick, graded bed. However, the distance interval between sampling was sufficiently large that it would be unlikely for two samples to be taken from the same bed, considering few of the beds are particularly thick. To further support the improbability of stratigraphic division, it should be noted that the presence of well-developed graded bedding at the site has not been confirmed.

The first and deepest of the 12 test borings in this study has revealed two stratigraphic units (Plate A): a $8.9 \mathrm{~m}$ thick overbank unit, overlying a $7.8 \mathrm{~m}$ thick channel sand unit. Only the overbank unit is known to bear artifacts (Broyles 1971), so the remaining 11 test borings were terminated upon reaching the sand unit. All 12 borings show the overbank and channel facies transition between $8.2 \mathrm{~m}$ and $9.0 \mathrm{~m}$ depth.

Weathered, pinkish, shale bedrock is encountered at $54.6 \mathrm{ft}$ deep in core \#1. This shale bedrock has been reported as often having a blue-grey color (Doll, 1960). A $0.6 \mathrm{~m}$ gravely sand bed 
lies on top of the weathered bedrock. The textural analysis determination of gravely sand for this bed could be inaccurate because a 2 inch diameter split-spoon does not have the potential to retrieve larger clasts that may be present in that bed. Therefore, due to the limitations of the split-spoon, this bed may be undetectably more coarse. A $7.0 \mathrm{~m}$ thick sand unit occurs above this gravely sand. The bottom $1.4 \mathrm{~m}$ of the $7.0 \mathrm{~m}$ thick sand is actually a loamy sand. This loamy sand coarsens upward to sand, which also becomes progressively more coarse upward. An overbank facies occurs on top of the sands. Most of the overbank facies can be broken into two general textural units: silt loam and loam. The lower of these units is a 2 to $5 \mathrm{~m}$ thick silt loam. Generally, this silt loam thickens to the east and thins to the west. A thin, but continuous, loam bed runs the length of the site through the middle of this silt loam. Other discontinuous, lens-like, loam beds occur within the silt loam unit. In general, these lens-like loams are more abundant to the east end of the site.

The contact between the lower silt loam unit and the overlying loam unit is somewhat irregular and suggests erosion. Floods may have eroded part of the top of the lower silt loam unit or tributaries draining from the valley wall toward the river may be responsible for some dissection of the top of the silt loam. Some of this contact irregularity may be an artifact 
of stratigraphic misrepresentation due to delineating the stratigraphy only by texture. However, stratigraphy at the west end of this study beneath core \#8 (Plate A) suggests a cut-andfill structure at this elevation. One of Broyles's (1971) excavations exposed a cut-and-fill structure at a depth similar to a possible cut-and-fill structure beneath core \#8 (Fig. 8). Broyles's (1971) cut-and-fill structure displays thin, convex upward stratigraphy. The structure also displays the thalweg of the channel migrating vertically and horizontally as the depth of the convexity decreases, indicating the channel shallowed. This stratigraphy suggests a slow southward migration during infill that would have required a persistent flow in the channel for a greater duration than a flood scour. This cut-and-fill structure may also have been created by one of the small tributaries draining from the south valley wall toward the river. Again, the structure is too small to have been created by the entirety of the Kanawha's main channel. Therefore, an unconformity may exist between the lower silt loam unit and the loam unit just above. The upper, overbank unit is a loam, 3 to $5 \mathrm{~m}$ in thickness. This loam unit tends to thicken to the west. The possible cutand-fill structure beneath core \#8 at the west end of the site will be considered a part of this upper loam unit, although it would be more appropriate to break the cut-and-fill structure into a separate unit if its development were more conclusive. A 


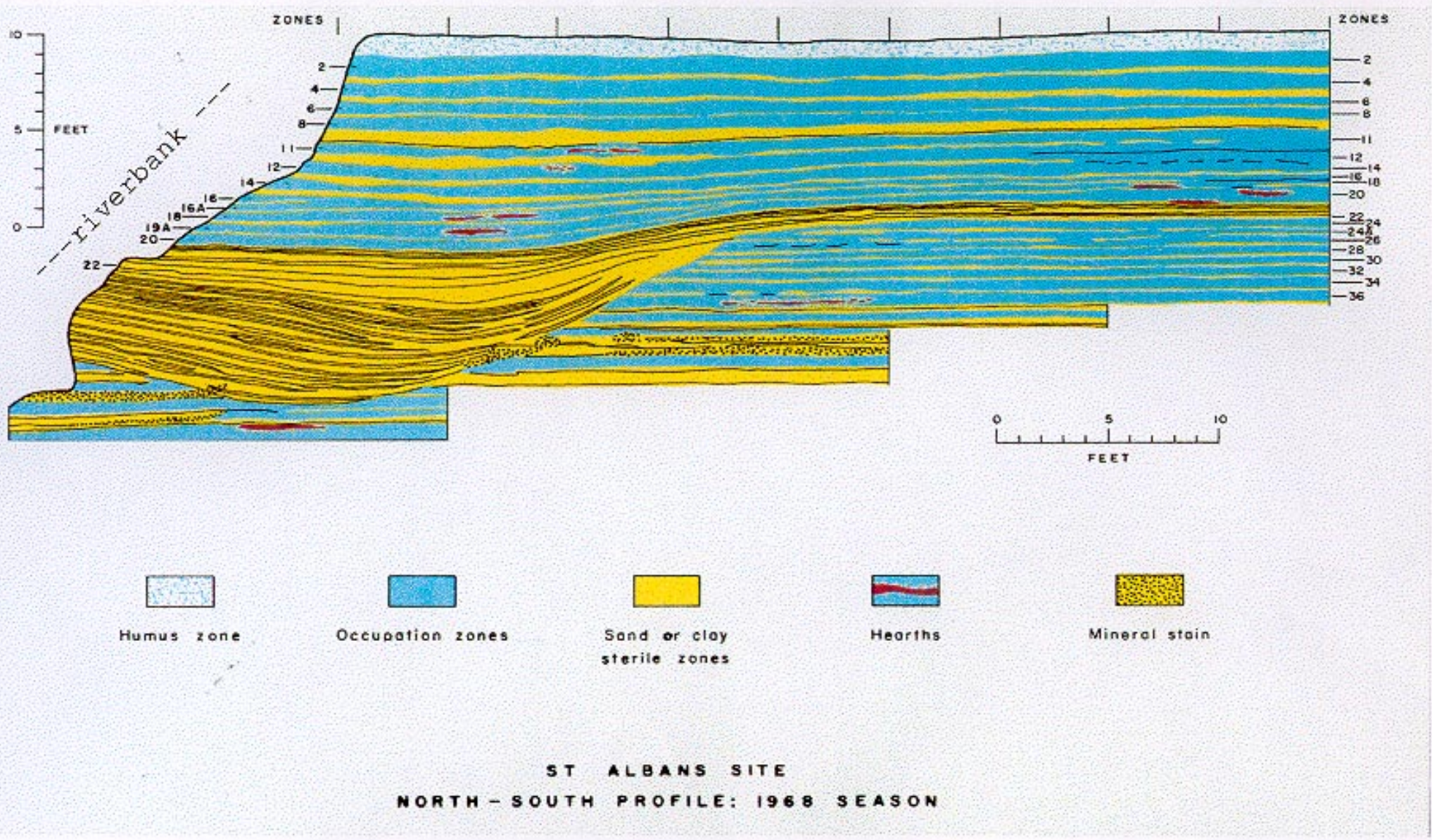

Figure 8. Broyles excavation showing cut-and-fill structure (After Broyles, 1971 ). Note: None of the cores in this study are a part of this cross-section. 
silt loam bed occurs within the middle of this loam unit but pinches out before reaching the east or west ends. The loam unit grades into a sandy loam east of core \#7.

A 5 to $50 \mathrm{~cm}$ thick sand bed, lies above the upper loam unit. This sand bed runs most of the length of the site but grades into a loamy sand at the eastern end. Because the bed is thin, it has a coarse texture indicative of high energy and this texture is anomalous to the sediments above and below, this bed is interpreted to be a single, large-magnitude flood deposit. The uppermost 50 to $150 \mathrm{~cm}$ of the stratigraphy at the site is dominated by a mixture of loams and sandy loams that have been truncated by highway construction. Generally, the sandy loams of this uppermost stratigraphy occur to the east and west ends of the site and the loams occur in the central reaches.

The stratigraphy in the river bank is largely consistent with that in the cores. However, the stratigraphy in the river bank is more coarse-grained, and the beds are thinner and more prominent. Numerous thin sand beds must pinch out away from the river, as they are not present in the cores. Beds that correlate between the river bank and the cores occur at shallower depths in the river bank because the river bank sediments were deposited closer to the crest of the levee deposits and are up-dip from sediments deposited farther inland. The overbank sediments at the bottom of the west river bank profile display a transition from 
lower stratigraphy dipping gently toward the river to upper stratigraphy dipping gently away from the river. This reverse in dip was also observed at comparable depths by Broyles (1971). The depth of this transition in dip is about the same depth as the transition from silt loam to loam in the cores. The stratigraphy above this transition is interpreted to be indicative of singlechannel flood-related levee deposits.

Little can be said about the nature of the fluvial regime responsible for the deposition of these overbank sediments due to the lack of sedimentary structures in both the cores and river bank. Perhaps any sedimentary structures have been destroyed by bioturbation. The particular fluvial environment responsible for the deposition of the underlying channel sands is also not supported by sedimentary structures. The channel sands are not exposed in the river bank and the slit-spoon samples are too small and distorted to yield good sedimentary structures. However, cores taken in this study and cores documented in other papers (Doll, 1960; Barlow, 1971) show sands at depth in all cores taken on the lower terrace of the valley. These sands suggest that the lower stratigraphy across most of the valley, except under the Wisconsin terrace, is a laterally continuous sand sheet. According to Walker (1984), laterally continuous, extensive sand sheets may be indicative of braided system deposits. 


\section{RADIOCARBON DATES}

Many new radiocarbon dates have been acquired since Broyles's (1971) report (Table 1). Four of these dates come from excavation units, one comes from a core sample and another comes from a West Virginia Department of Highways river-bank stabilization project. Radiocarbon dates of $8,720 \pm 250$ B.P. $($ Beta-50422), 8,570 1130 B.P. (Beta-50424) and 8,160 \pm 100 B.P. (Beta-50723) come from features 2, 4, and 8 respectively (Brashler and others, 1994). Another date of 9,110 120 B.P. (Beta-52904), comes from the bank profile approximately $60 \mathrm{~cm}$ below feature 4 which produced the $8,570 \pm 130$ B.P. (Beta-50424) date. A fifth date of 5,500 \pm 450 B.P. (Pitt-1053) came from core \#3. And the final date of 12,910 \pm 60 B.P. (Beta-102187) comes from the WVDOH river-bank project approximately one-half mile downstream from the western end of the site.

The first four of these dates correlate well with Broyles published dates for St. Albans. However, the 8,160 $\pm 100 \mathrm{~B} . \mathrm{P}$. (Beta-50723) date is relatively recent considering its depth. The $5,500 \pm 450$ B.P. (Pitt-1053) date is extremely recent considering its depth of 4.3 to $4.4 \mathrm{~m}$. This sample, collected from a 2 in diameter core, was too small to be fully pretreated to remove "young carbon." This date should not cause alarm because its accuracy is highly suspect (Stuckenrath, Robert, personal communication to Kite, 1992). 


\begin{tabular}{|c|c|c|c|c|}
\hline Lab Number & Date & Provenience & Depth m* & Source \\
\hline M-1827 & $9850+/-500$ & Charleston Horizon Zone 36 & $4.8-5.1$ & Broyles: 1971 \\
\hline Y-1538 & $8390+/-160$ & Lower Kirk Horizon Zone 20 & $3-3.24$ & Broyles: 1971 \\
\hline M-2294 & $8850+/-320$ & Mid. Kirk Horizon Zone 18 & $2.7-3.0$ & Broyles: 1971 \\
\hline M-2289 & $8800+/-320$ & Upper Kirk Horizon Zone 16 & 2.6 & Broyles: 1971 \\
\hline M-1821 & $8830+/-700$ & Lower St. Albans Zone 12 & $2.1-2.4$ & Broyles: 1971 \\
\hline M-1820 & $8820+/-500$ & Upper St. Albans 11 & $1.7-2.1$ & Broyles: 1971 \\
\hline Y-1539 & $8250+/-100$ & Upper Le Croy Zone 6 & $1.0-1.3$ & Broyles: 1971 \\
\hline Y-1540 & $8160+/-100$ & Kanawha Horizon Zone 4 & 0.7-.098 & Broyles: 1971 \\
\hline M-2288 & $8470+/-300$ & Zone 24, Intermediate Horizon & $3.5-3.8$ & Anslinger: 1998 \\
\hline M-2291 & $9330+/-330$ & Zone 20, Lower Kirk Horizon & $3.0-3.2$ & Anslinger: 1998 \\
\hline M-2295 & $8560+/-600$ & Zone 19A, Kirk Horizon & $3.0-3.2$ & Anslinger: 1998 \\
\hline M-1824 & $8520+/-300$ & Zone 20, Lower Kirk Horizon & $3.0-3.2$ & Anslinger: 1998 \\
\hline M-2292 & $8240+/-300$ & Zone 12, Lower St. Albans Horizon & $2.1-2.4$ & Anslinger: 1998 \\
\hline M-2293 & $9000+/-600$ & Zone 11, upper St. Albans Horizon & $1.7-2.1$ & Anslinger: 1998 \\
\hline M-1818 & $7700+/-450$ & Zone 6, Upper LeCroy Horizon & $1.0-1.3$ & Anslinger: 1998 \\
\hline BETA-50422 & $8720+/-250$ & $\begin{array}{l}\text { St. Albans (?) F.2 ('91) Excavation Unit } \\
\text { 7N15E }\end{array}$ & $2.5-2.6$ & Brashler et al. :1992 \\
\hline BETA-50424 & $8570+/-130$ & St. Albans (?) F.4 ('91) Profile- Area A & 2.9-3.0 & Brashler et al. :1992 \\
\hline BETA-50723 & $8160+/-100$ & Kanawha (?) F.8 ('91) Profile Area B & 3.6 & Brashler et al. :1992 \\
\hline BETA-52904 & $9110+/-120$ & Profile Area A & 3.6 & Brashler et al. :1992 \\
\hline PITT-1053 & $5500+/-450$ & Core Drill 3 & 4.3-4.4 & Brashler et al. :1992 \\
\hline BETA-54201 & $7930+/-90$ & Unit 3N110W (L.5) & $2.05-2.12$ & $\begin{array}{l}\text { Freidin: } 1993 \text { pers. } \\
\text { comm. }\end{array}$ \\
\hline BETA-102187 & $12,910+/-60$ & D.O.H. Bank stabilization Project & 4.8 & Anslinger: 1998 \\
\hline BETA-102188 & $7890+/-50$ & D.O.H. Bank stabilization Project & 4.2 & Anslinger: 1998 \\
\hline
\end{tabular}

*Depths for Broyles dates are reconstructed from Figure 37 (Broyles, 1971:49)

Table 1. Radiocarbon dates from the St. Albans vicinity (Anslinger, 1998;

Brashler, 1993). 
The $12,910+/-60$ B.P. is extremely old considering its depth of 4.7 to $5.4 \mathrm{~m}$. This date comes from an area downstream that was not considered part of the site prior to Anslinger (1998). Because there is no reason to suspect that this date comes from a reworked sample, this date may represent a deposit from an older landform.

It should be noted that Broyles did not publish seven radiocarbon dates from her site. Apparently these dates were not reported because of the order in which they were returned from two different laboratories; the dates obtained after 1966 being slightly inconsistent with the chronology established from the earlier dates (Brashler and others, 1994; Hemmings, 1985). It has been suggested that Broyles might have only accepted dates that supported a developing trend where occupationally sterile zones separated zones that averaged 80 years occupation (Brashler and others, 1994; Hemmings, 1985). These dates were published later by Anslinger (1998). All but one of the seven dates fit within the age bracket of the reported dates. The seventh date is relatively close in age to this bracket. It appears that the dating of the site was not as consistent as reported by Broyles (1971). Despite the inconsistency, the dating of the sediment sequence as a whole still seems to be legitimate. Moreover, dates obtained from new excavations at the site are in good agreement with Broyles's reported dates. 


\title{
ALLUVIAL HISTORY
}

\author{
Although local climate was a factor in the development of \\ the Kanawha River low terraces, as proposed by Olafson (1971) and \\ Barlow (1971), an apparent mimicking of alluvial events on the \\ Ohio River suggests that formation of the Kanawha low terraces \\ was largely controlled by preceding events on the Ohio River. \\ Specifically, incision and aggradation events on the ohio \\ (Rogers, 1990) were responsible for lowering and raising base \\ level of the Kanawha River. The Kanawha River's complex response \\ to these base-level adjustments is the proposed mechanism by \\ which the Kanawha's two lowest terraces formed. \\ The Ohio River, was responding to dramatic shifts in \\ sediment supply and glacial meltwaters in addition to local \\ climate changes during the glacial advances and retreats. Glacial \\ meltwater brought in large amounts of outwash from completely \\ different terrains and probably produced large floods, perhaps \\ catastrophic jolkulups (Rogers, 1990). Therefore, the Ohio River \\ was experiencing the direct effects a global climatic phenomenon \\ while it was responsible for establishing base level for the \\ Kanawha . \\ Before 22,000 B.P., the Ohio River incised to a bedrock \\ (fig. 4) elevation of $152 \mathrm{~m}$ (498 ft) in the vicinity of \\ Gallipolis Lock and Dam (Rogers, 1990; Kite and others, 1990).
}


This incision was probably associated with large floods as glaciers advanced into the upper Ohio River basin (Rogers, 1990). Around 22,000 to 21,000 B.P. the full-glacial Ohio River began to experience an aggradation; the thickness would ultimately reach a minimum of $25 \mathrm{~m}$ (Rogers, 1990). This aggradation was probably rapid until 19,000-18,000 B.P., when glaciers began to retreat. Although glacial ice was not completely gone from the basin until about 12,900 B.P. (Kite, 1993), the amount of outwash sediment contributed to the basin by this ice may have been insignificant by as early as 14,500 B.P. As the climate became warmer, increasing vegetation may have further stabilized slopes that produced much sediment in the Ohio River Basin (Kite, 1992). The late Wisconsin aggradation on the Ohio River raised local base-level, causing an aggrading event on the Kanawha River. Perhaps the aggradation on the Kanawha followed that of the Ohio with a lag time in the neighborhood of a few hundred years. This aggradation produced high terraces in both the Ohio and Kanawha Valleys. This aggradation is documented as surface 3 at Gallipolis, Ohio (Fig. 4), which is underlain by $25 \mathrm{~m}$ (88 ft)

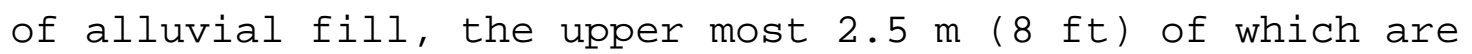
overbank deposits (Rogers, 1990). The corresponding St. Albans terraces are approximately 610 ft in elevation (Fig. 7).

After this aggradational event, the Ohio River experienced $21 \mathrm{~m}$ of incision (Fig.4), which was nearly complete before 13,000 
B.P. (Rogers, 1990). This down-cutting caused a dramatic lowering of Kanawha River base-level, which, in turn, initiated a complex response in the Kanawha River basin. The complex response is best expressed by Schumm (1973), describing observations he made following a base-level lowering on an experimental $9 \mathrm{~m} \times 15 \mathrm{~m}$ drainage system:

"Incision occurred first at the mouth of the system, and then progressively upstream, successively rejuvenating tributaries and scouring the alluvium previously deposited in the valley. As erosion progressed upstream, the main channel became a conveyor of upstream sediment in increasing quantities, and the inevitable result was that aggradation occurred in the newly cut channel. However, as the tributaries eventually became adjusted to the new base levels, sediment loads decreased, and a new phase of channel incision occurred."

The $9 \mathrm{~m} \times 15 \mathrm{~m}$ "system" in the above quotation is analogous to the Kanawha River; however, it should be noted that although the Ohio River may not have experienced a base-level lowering during the late Quaternary, it did experience much of the same phenomenon. Large scale Ohio River aggradation and incision events were largely the result of variations in glacial sediment and meltwater, rather than base-level changes. Therefore, rejuvenated tributaries must have transported much sediment to the Ohio in response to large scale incision on the Ohio River. So, the Ohio River was probably involved in a different, but similar complex response.

In this complex response to Ohio River incision, incision began at the mouth of the Kanawha as sediment was transported 
into and down the actively incising Ohio River. As the incision progressed upstream, more and more tributaries became rejuvenated, producing increasing quantities of sediment. Eventually, the supply of sediment to the Kanawha, from all tributaries enveloped in this response, exceeded transport capacity. The Kanawha system became sediment choked and renewed aggradation slowly began to build the present St. Albans Site terrace. For some time, aggradation probably occurred at the mouth of the Kanawha River, while simultaneously, still under the drive of the previous incision event, headward incision continued at the upstream reaches of the Kanawha. Eventually, the wave of incision that worked its way up the Kanawha would be followed by a wave of deposition that produced the St. Albans terrace. The effect on the landscape at St. Albans from this series of events was: first, incision of the channel removed much of the underlying support of the late Wisconsin low terrace scarp. As incision progressed, the scarp would begin to slump and cave into the channel, releasing valley alluvium from storage and transporting it downstream. An estimate of the amount of scarp erosion can be established by viewing the amount of late Wisconsin terraces left behind along the valley walls. Assuming most of the distance between the remnants of this terrace was due to the river eroding its scarps; subtracting a channel width comparable to the present day Kanawha River, a maximum value of 
$650 \mathrm{~m}$ to $900 \mathrm{~m}$ of scarp erosion is calculated for the St. Albans vicinity (Fig. 9, A\&B). These terraces have probably continued to erode until present time due to surficial processes. Additionally, the previous channel width may not have been comparable to the present channel and therefore the actual amount of widening that took place prior to 13,000 B.P. is uncertain. The amount of widening greatly increases downstream from st. Albans and decreases upstream. For example, except for a small remnant of the late Wisconsin terrace near the mouth of the Kanawha River, few remains of the terrace can be found between the mouth and $36 \mathrm{~km}(22.5 \mathrm{mi})$ upstream from the mouth. At distances greater than $32 \mathrm{~km}$ (20 mi) upstream from st. Albans, the late Wisconsin terrace can not be resolved topographically from the st. Albans terrace.

The lower limit of this incision set the boundary for an unconformity that should exist somewhere in the channel sand deposits seen in the lower portions of core \#1 (Plate A). No data are available to support a depth determination for this unconformity. Because the Kanawha River incision was only a response and did not have the large magnitude flooding that is suspected to have aided in the $21 \mathrm{~m}$ of Ohio River incision (Rogers, 1990), incision of the Kanawha River during this event would be expected to be significantly less than $21 \mathrm{~m}$. If this incision event was great enough to reach bedrock as proposed 


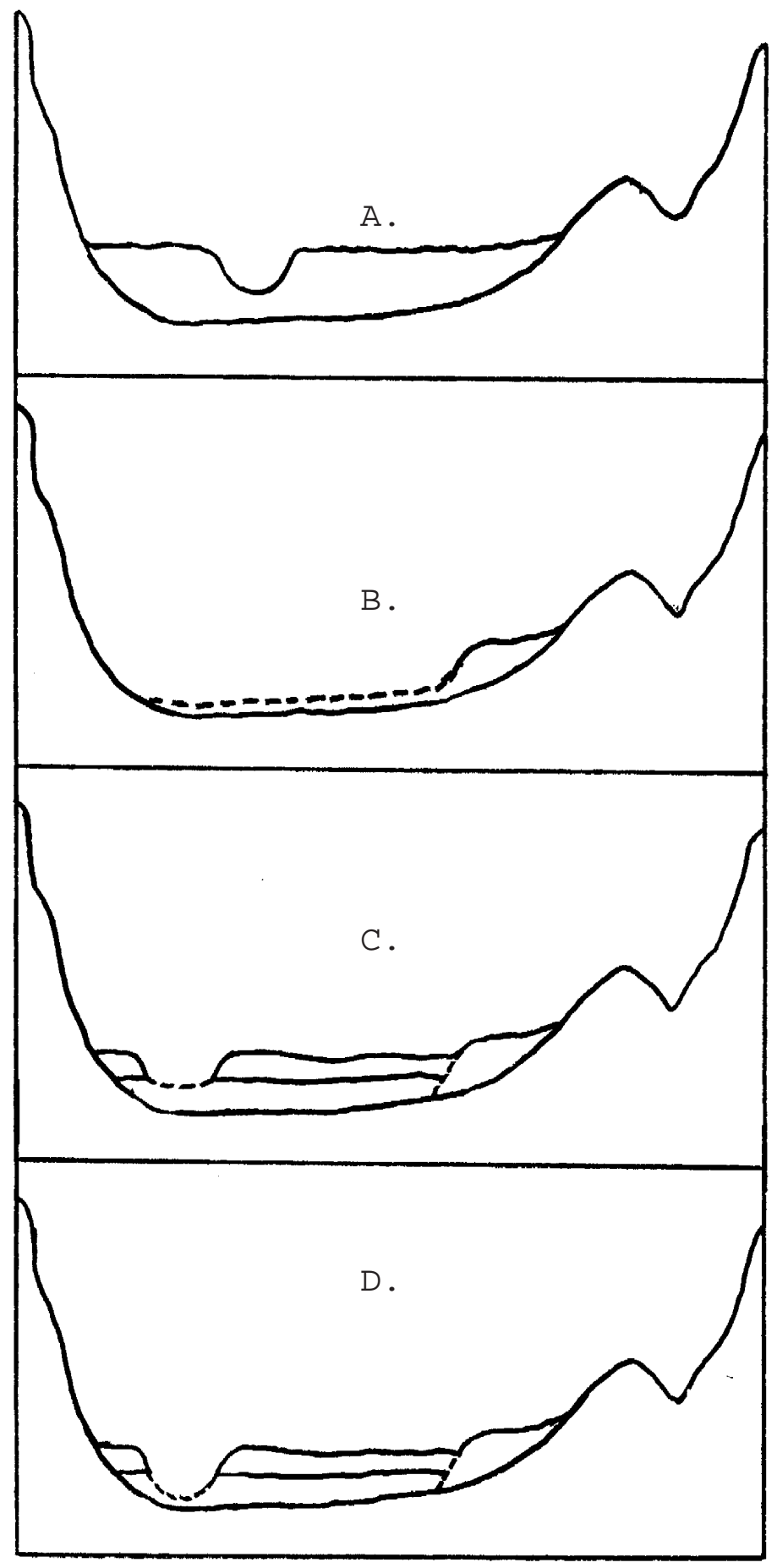

Figure 9. Alluvial history of Kanawha valley at St. Albans.

A. Time - less than 21,000 B.P. greater than 14,500 B,P.

B. Time - less than 14,500 B.P. greater than 12,900 B.P.

C. Time - less than 8,000 B.P.

D. Time - present, channel has incised and an additional 1 to $2 \mathrm{~m}$ of sedimentation since time $\mathrm{C}$. 
(Barlow, 1971), then all $7.8 \mathrm{~m}$ of the channel sand unit underlying the archaeologic site would have to be considered a part of the following aggradational event.

After the incision event was complete a new aggradational event occurred. A radiocarbon date of 12,910 +/- 60 B.P. (Beta102187) was obtained from the river bank at a depth of $4.8 \mathrm{~m}$, approximately one half a mile downstream from the site (Anslinger, 1998). Because this depth is roughly $4 \mathrm{~m}$ above the channel loverbank facies transition that has been established for most of the valley in the st. Albans vicinity including the archaeologic site, this aggradational event must have begun significantly before 12,910 B.P. in order to account for the deposition of this underlying $4 \mathrm{~m}$ of overbank sediments and any additional channel facies sediments above the lower limit of the previous incision event. Additionally, dates from this depth at the archaeologic site, approximately one half mile up-stream, would be roughly three thousand years younger. Therefore, this 12,910 +/- B.P. (Beta-102187) date is interpreted to have come from an older and different landform than the landform of the archaeologic site (Fig. 10). Most of the radiocarbon date control for this terrace comes from sediments at, or close to, the present river bank. Therefore, to explain the age discrepancy among the $12,910+/-60$ (Beta-102187) date and the dates established at the archaeologic site, both of which come from 


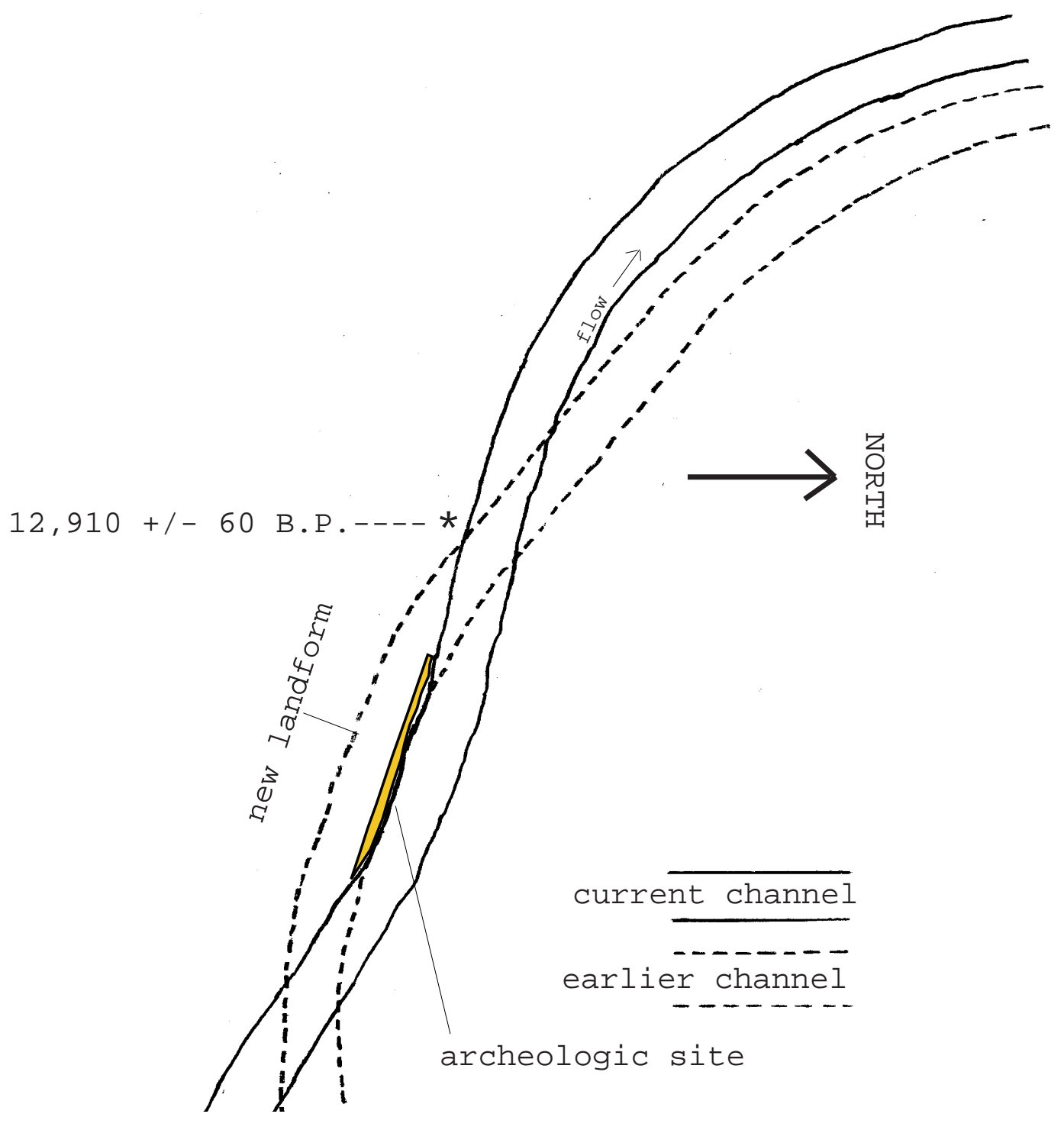

Figure 10. Possible channel migration that could explain a landform at the st. Albans site that is younger than the landform that produced radiocarbon date 12,910 +/- 60 B.P. (Beta-102187). 
sediments very close to the present river bank: it is interpreted that the sediments of the archaeologic site were deposited later, on the inside of a slight meander bend as the channel migrated to the north. The older, downstream area of the terrace was in a location that did not experience erosion from the channel migrating toward it or experience lateral accretion from the channel moving away from it. Part of the stratigraphy in the older landform was preserved in the present river bank position as the younger sediments of the archaeologic site were deposited during a slight channel migration to the north.

There is an elongated ridge-like feature approximately $150 \mathrm{~m}$ to $275 \mathrm{~m}$ inland from the present river bank. A 590 ft contour line conveniently outlines this feature (fig. 7). This ridge-like feature may represent the inland expression of the older landform. This ridge-like feature may have been a levee, much like the levee at the archaeologic site. If so, then it appears that at some time during overbank deposition for the St. Albans terrace, the river channel in the st. Albans vicinity was positioned centrally with respect to the valley walls.

Sometime after $12,910 \mathrm{BP}$, sedimentation on the older landform would have continued as sedimentation began on the new landform. Broyles's (1971) two deepest reported radiocarbon dates for the new landform are $9850+/-500$ B.P. at $4.8 \mathrm{~m}-5.1 \mathrm{~m}$ and $8930+/-160$ B.P. at $3.0 \mathrm{~m}-3.24 \mathrm{~m}$. These dates represent 
$1.83 \mathrm{~m}$ of sedimentation that could have occurred in as little as 260 years or up to 1580 years. Using the lowest and highest sedimentation rates that can be calculated from these values, the deposition of the $8.9 \mathrm{~m}$ of overbank sediments could have begun as early as 13,750 B.P. or as late as 9,900 B.P.. Both of these dates are probably unrealistic because they represent extremes. Because overbank sedimentation rates at the site appear to be greater at the beginning of overbank deposition, a significant bias toward the 9,900 B.P. date exists.

It appears that the new landform overbank deposition began between 9,900 B.P. and 13,750 B.P. and continued to within $2 \mathrm{~m}$ to $3 \mathrm{~m}$ of total aggradation by roughly 8,000 B.P.. The remaining aggradation occurred over the last 8,000 years. The depth of this 8,000 B.P. horizon is difficult to determine because up to $6 \mathrm{ft}$ of sediment was removed during construction of Route 60 (Barlow, 1971). Upon visual inspection of the terrain, the amount of this sediment removal was apparently not entirely consistent throughout the site.

The cross-section (Plate A) shows evidence of a possible cut-and-fill structure at depths comparable to the cut and fill structure in Broyles's (1971) excavation (fig. 8). The strata overlying the 12,910 +/- 60 B.P. radiocarbon date also displayed a cut-and-fill structure. These structures may represent the old paths of the small streams that drain from the valley wall. The 
deepest part of the first two of these structures occur near the transition where stratigraphy starts to dip away from the river. So they existed as the levee began to form but later changed course. The existence of a levee on the older landform is inconclusive. Before levee formation the floodplain topography probably sloped gradually from the valley wall to the Kanawha channel. The small streams would flow down this gradient in a more direct route to the Kanawha. After the levee developed, these small streams may have become blocked and forced to flow like typical yazoo streams until encountering a weak or low spot in the levee, such as a crevasse splay. In other cases, these streams may have been able to maintain their course by preventing levee build up. Because these small cut-and-fill structures have been discovered in several exposures in the St. Albans vicinity, it is possible that the two significant tributaries that drain from the valley wall produced these cuts because they had to adjust their course several times during aggradation of the terrace levee. Currently, these two tributaries follow highly lateral routes to the Kanawha River. Topographic maps of the valley, show many streams taking these highly lateral routes, while others take more direct routes, bisecting apparent levees. The resulting overbank deposits of the new landform make up a coarsening-upward sequence up to $9 \mathrm{~m}$ thick. Part of the reason that the sequence coarsens-up may be that fines were the first 
sediment to be flushed downriver during the new entrenching episode. Also, the overbank surface was building higher, making an ever deepening channel, requiring progressively higher magnitude floods to inundate the floodplain. Higher-magnitude floods had more energy to carry and deposit more coarse sediment. Eventually, the site became a levee. Levee development would further act to confine flood waters that would otherwise quietly spill out onto the floodplain. A confined flood has to compensate restricted cross-sectional channel area by an increase in velocity that would increase energy and competence. Therefore, progressive levee development could result in a coarsening upward overbank sequence. Consequently, silt loam makes up the bulk of the lower portions of the overbank sequence and loam makes up the bulk of the upper portions.

The sediments of the new landform represent roughly 9,900 to 13,750 years of aggradation. Because these sediments display stratigraphy indicating a levee, the sediments must have been deposited in a position immediately adjacent to the river. It appears that the present channel position with respect to its placement between the valley walls has not significantly changed during this time. Therefore, the river system has expended little energy into lateral channel adjustment during the deposition of the new landform. According to Barlow (1971), the channel bottom is approximately 50 ft below the present terrace surface. This 
depth is approximately $20 \mathrm{ft}$ below the channel/overbank facies interface and $5 \mathrm{ft}$ above bedrock. The size of the Kanawha River drainage basin at st. Albans is roughly 11,000 square miles (Ward and others, 1997). A typical river channel in an eastern U.S. basin of this size has a bank-full depth of about 25 ft (Dunne and others, 1978). Therefore, as overbank deposition of the newer landform progressed, entrenching into the channel sands that underlie the overbank sediments has produced a channel that is roughly twice as deep as would be expected (Fig. 9,D.) This new episode of entrenching would probably not be as aggressive as the previous episode because it was not being driven by a glacially dictated base-level drop. Instead, part of this incision was in response to a decline in sediment yield. Much of the sediment that had been put into the system from the previous incision event had been put back into valley storage as the new terrace aggraded. The volume of sediment deposited since the beginning of the last aggradation to approximately 8,000 B.P. greatly exceeds that which has been deposited after 8,000 B.P.. The amount of energy the stream had to expend in transporting all of this sediment greatly declined. Also, the channel was established on top of a thick sequence of noncohesive, relatively clean, fine sands, some of the most easily erodible of sediments, according to the Hulstrom diagram. Therefore, the Kanawha River prior to lock and dam construction, probably was experiencing active 


\begin{tabular}{|l|l|}
\hline \multicolumn{1}{|c|}{ Radiocarbon years B.P. } & \multicolumn{1}{|c|}{ Event } \\
\hline$>8,000$ to present & entrenching into channel sands \\
\hline$>12,900$ to present & deposition of overbank \\
& sediments \\
\hline$<14,500$ to $>13,000$ & deposition of channel sands \\
\hline$<21,000$ to $>14,000$ & incision of Wisconsin terrace \\
\hline$<22,000$ to $>14,000$ & aggradation of Wisconsin \\
& terrace \\
\hline
\end{tabular}

Table 2. Summary of the geologic history of the St. Albans and Wisconsin terraces, adapted from Rogers (1990). 
incision with little lateral channel adjustment.

\section{MAGNETIC SUSCEPTIBILITY}

Magnetic susceptibility is "a measure of the degree to which a substance may be magnetized" (Sheriff, 1991). Magnetic susceptibility measurements are made by applying a low-intensity alternating magnetic field and measuring changes in the frequency of this field in response to the magnetic minerals in the sample (Clark, 1990).

Five general causes for high susceptibilities in transported soil are the following:

Fire: The low-oxygen, high-temperature conditions at the base of a fire cause low-susceptibility hematite to alter to highsusceptibility magnetite. Incomplete reoxidation of magnetite during cooling produces intermediate-susceptibility oxides, such as maghemite (Tite and Mullins, 1971).

Fermentation: During decay of organic matter in anaerobic conditions, fermentation can produce intermediate-susceptibility oxides (Tite and Mullins, 1971).

Pedogenesis: Iron sesqueoxides created during pedogenesis include maghemite and other intermediate-susceptibility minerals (Mullins, 1977).

Provenance: Proportions of magnetic minerals differ with changing source-area geology (Tite, 1972; Clark, 1990). Anomalies 
of the provenance type may be most useful as marker beds for correlation.

Particle size: Magnetic minerals are not uniformly distributed with respect to particle size. Relationships between susceptibility and particle size vary with mineralogy; quartzrich sands give low readings, but mafic sands give high susceptibilities.

Buried horizons indicative of soil-profile development were the initial target of the magnetic susceptibility investigations at St. Albans. The magnetic susceptibility meter has proved useful in delineating buried soil horizons in Midwest loess deposits (Lowell, 1991). If the meter could delineate welldeveloped buried soil profiles at St. Albans, these horizons would have a high probability of containing artifacts due to the long-term stability required for soil-profile development. This stability would allow accumulation of artifacts in concentrated horizons that would be productive for excavation. However, no buried soil horizons were found at the site. The lack of buried soil-profiles could reflect either rapid and consistent sedimentation or the erosion of any soil profiles.

The Bartington MS-2F magnetic susceptibility meter gave high readings on reddened soils that are believed, in most cases, to be cultural fire hearths because of the associated occurrence of charcoal, fire-cracked rock, flint flakes, and artifacts. Most of 
these cultural remains occurred in sediments exposed along the river bank or in test pits where exposure was extensive enough to show the lateral extent of a particular hearth.

The cause of high susceptibility readings in the cores is more difficult to verify due to lack of lateral exposure. High readings commonly occur in horizons within the cores lacking reddened soil, charcoal, fire-cracked rock or other cultural associations. The lack of these associations in the cores could be explained by the limited lateral extent of exposure of horizons in the cores. Essentially, the cores only provide a tiny window into the features they penetrate. A core might intersect a horizon in a weakly developed portion of a hearth and thereby give a relatively high reading from a sample that is not visually distinct. Furthermore, a test boring may "just miss" several nearby hearths and give an erroneous impression of sterility of the horizon.

The other causes of high magnetic susceptibilities in transported soils further complicate the picture. Fermentationcaused highs may reflect cultural or noncultural sources depending on the material decaying. Fermentation may have taken place on human waste or natural leaf mats and organic flood debris.

Sediment source area changes could be a factor in the susceptibilities. For example, the iron contained in a source 
rock may exist as a stable nonmagnetic silicate that would not easily be converted to a strongly ferrimagnetic iron oxide (Tite, 1972). Conversely, the source rock may contain strongly ferrimagnetic minerals that are high in magnetic susceptibility without the need for conversion (Tite, 1972). However, sediment source area it is not likely to be significant factor at the site because of the relative homogenous appearance of sediments. In other words, no key provenance indicative marker beds seem to occur at the site. Particle size does have a control on the susceptibility of the site's soils, however, this influence is most likely subtle and is not believed to overprint fire-induced susceptibilities in the overbank facies. Gravelly sand, sand and loamy sand textured sediments have notably lower magnetic susceptibility than sandy loam, loam and silt loam textured sediments (Plate A). These more coarse textured sediments are from channel facies that are not significant to the cultural importance of magnetic susceptibility. Because the Kanawha River bedload includes very little mafic sediment, quartz content is the delimiting factor with respect to particle-size control of the susceptibility of the site's sediment. Quartz is the predominant mineral in the coarse sediments at the site. Because quartz contains almost no iron, it is not magnetically susceptible when exposed to high heat. Sediments with more fines and less quartz have more potential to become magnetically 
susceptible because there is a greater chance these sediments will have iron-bearing minerals, such as hematite, maghemite and magnetite.

Forest fire is a possible cause of increased magnetic susceptibility at the site. Any reddened soil that does not display some form of cultural relation cannot be confidently assumed to be culturally related. On the other hand, cultures may have engaged in widespread burning. If they did practice widespread burning, there may be no way to distinguish this practice from a natural forest fire as the cause of high-magnetic susceptibility. To be confidently attributed to culture, a hearth should be relatively small, lens shaped, and contain some associated artifacts. A forest fire would be expected to produce an extensive blanket of high magnetically susceptible sediments.

Lowell (unpublished data) has shown that the approximate minimum volume required for the meter to give a full strength reading is a sample that would occupy a typical $35 \mathrm{~mm}$ film canister. The smaller core samples in this study have a larger diameter than a 35mm film canister, therefore, readings taken on the 2 inch and 3 inch cores should be comparable to those taken on the test pits and riverbank. Because the sediments in the riverbank are somewhat more coarse than the core sediments, background magnetic susceptibility values in the riverbank are a little lower. 
Soils at the surface of the site consistently yield highmagnetic susceptibility readings (Plate A). These high readings are the result of soil-profile development and the generation of iron sesqueoxides through pedogenesis (Mullins, 1997), and the subsequent horticultural practices upon the soil (Brashler, 1994). The site was used for gardening and fires were built on the soil in the recent past. These practices definitely would increase the magnetic susceptibility of the soil. Below the surface, magnetic susceptibility measurements are as high as 220 CGS units for burnt earth, compared to values of 14 to 30 CGS units for unburnt silty loam, and 10 or less for unburnt sand (Plate A).

All cores show peaks in magnetic susceptibility between $1 \mathrm{~m}$ and $7 \mathrm{~m}$ depth (Plate A). In most instances, these peaks do not correlate to delineate artifact-bearing horizons, however, many peaks probably reflect recurring occupation of the site. Magnetic susceptibility values tend to decrease below a depth of $4.5 \mathrm{~m}$, in spite of a coarsening upward trend in the overbank alluvium. This tendency may reflect less human activity in older deposits or alteration of magnetic minerals by soil or groundwater. Furthermore, some peaks occur in sediments that appear to have never been burnt. In these cases, reworking, bioturbation or foot traffic through old hearths may have destroyed hearth integrity beyond recognition, or small portions of hearths may have been 
transported or dispersed away from the original hearth to the area of sampling. In other cases, as expected of the peak in the bottom of core \# 11, iron-rich groundwater precipitates may be responsible for highs not linked to burning. In spite of these complications, most highs in magnetic susceptibility are most likely cultural in origin.

\section{SEDIMENTOLOGIC AND MAGNETIC SUSCEPTIBILITY MODEL}

This model links radiocarbon, sedimentological and magnetic susceptibility data for the purpose of aiding archeological investigations of the site. The model will bring together these data to evaluate the cultural resources potential of the site in three dimensions.

In the vertical dimension, levels below the overbank facies are assumed to be completely sterile as these sands have been interpreted to be channel facies. It is doubtful occupation occurred within a channel and any artifacts found there would be reworked from original context. Because the transition from channel to overbank deposition for the new landform is believed to have occurred between 13,750 and 9,900 B.P., it is unlikely that archeological development will lead to discoveries of occupation before this time. In this context, it is suggested that future archeological investigations should not be conducted below 9 to 10 meters as it would be expensive and dangerous to 
excavate below the water table in probable sterile sediments. Of the upper 9 meters of overbank sediments, the upper loam unit is probably going to be the most archeologically productive of the site's stratigraphy. Magnetic susceptibility levels drop off below $4.5 \mathrm{~m}$ depth, and this loam unit occupies most of the upper $4.5 \mathrm{~m}$ (Plate A). In spite of this trend, magnetic susceptibility peaks do occur much below 4.5 and previous excavations (Broyles, 1971) have discovered artifacts at $5.5 \mathrm{~m}$ and a possible hearth at $7.3 \mathrm{~m}$. The deepest occupations are the most interesting because they will tend to put a more specific dating constraint on the initial occupation of the site, while possibly proving the site to be one of the region's deepest and most consistently occupied through time.

In the north-south dimensions, the site's greatest potential most likely occurs at the northernmost extent of the site, in the levee deposits on the south bank of the Kanawha River. Recent riverbank erosion has removed those parts of the terrace that would have been closest to the river during times of occupation in the past. Assuming a desire for proximity to the river during times of occupation, the levee sediments should yield the most artifacts. Also assuming a desire for the highest ground available for reasons of defense and dryness, the levee crest would also be expected to produce the most archeology. Unfortunately, it appears that most of the levee crest has been 
lost to erosion. More than 20 ft of riverbank erosion has occurred between the years 1964 and 1974 (Henderson, 1991). Deep or shallow, east or west, the greatest potential for cultural resources occurs in the northernmost limit of the site, the riverbank. However, U.S. Route 60 is precariously close to the present south riverbank (Fig. 7), especially in the western end of the site where a riverbank stabilization project has been completed to increase the stability of this highway. Large-scale riverbank excavations would cause great concern for the endangerment this highway •

In the east-west dimension, magnetic susceptibility trends indicate that great potential exists at both ends of the site. Core \#10, taken at the easternmost end of the site, displays the highest average susceptibility for the upper $5 \mathrm{~m}$ of all cores taken at the site (Plate A). This end of the site would be expected to produce the most artifacts for the first $5 \mathrm{~m}$ interval. Core \#11, taken at the western most end of the site, displays high magnetic susceptibility peaks between 6 and 7.5 meters depth. This depth may correlate to a Paleo-Indian time of 10,000 B.P. or earlier (Broyles, 1971). Alternately, the Archaic Kirk interval may be lower at this end because US Route 60 construction did not include scraping this surface. This end of the site has already produced the most Woodland Indian artifacts (Brashler, 1994). The peak in this core below 9 meters is a iron- 
oxide precipitate and not of cultural importance.

Core \#13 displays the highest magnetic susceptibility peaks just above the channel facies. If this peak is culturally related, this would be an excellent place to excavate to determine the earliest date of occupation. Ironically, this location is adjacent to the Broyles' excavations of the 1960's, which have displayed the deepest occupations identified at the site thus far.

The highest magnetic susceptibility peak of the entire core survey occurs at $2.8 \mathrm{~m}$ depth in core \#3. This may indicate an archeological "hot spot" worth excavating. This peak correlates well with a hearth found at $2.84 \mathrm{~m}$ depth in adjacent square $7 \mathrm{~N} 15 \mathrm{E}$.

Because of the lens shape of the hearths, it is unlikely that they can be correlated over long distances. Therefore, unless extremely strong trends develop, high magnetic susceptibility readings are probably only representative of sediments in close proximity to the cores. No trends of this strength seem to appear in the data. The data produced from the magnetic susceptibility meter is probably most useful on a caseby-case basis. Rather than locating a new excavation by interpreting a correlation between cores, new excavations should be located in the exact location from which a core was taken, targeting a specific peak of interest. 


\section{DISCUSSION}

It cannot be determined from present data how deep the Kanawha River incised during the time between 21,000 B.P. and 14,000 B.P. because the lower sandy unit beneath the st. Albans terrace is not dated. The aggradation on the Kanawha River to form the St. Albans terrace would have probably started at least 1,000 years earlier than 12,910 B.P. to account for the deposition of the $4 \mathrm{~m}$ to $12 \mathrm{~m}$ of sediment before that date.

A date of $12,940+/-90$ B.P. was obtained from just above the unconformity that post dates $21 \mathrm{~m}$ of incision into surface $\mathrm{s} 3$ at Gallipolis (Fig. 4). Because this date was obtained just above the unconformity, deposition of terrace 52 above this unconformity must have begun very close to 12,940 B.P. Therefore, in contrast to the aggradation and following incision of the Kanawha River Wisconsin terrace ok reactions to Ohio River events, it appears that the deposition of the St. Albans terrace started independently, well before the deposition of surface s2 at Gallipolis.

The channel morphology during the aggradation of the st. Albans terrace is still unknown. The "old south channel" proposed by Barlow (1971) is now occupied by the two small tributaries that drain from the south valley wall (Fig. 3). One stream flows eastward, opposite Kanawha flow, and enters the Kanawha upstream from the site, while the other stream flows westward, parallel to 
the Kanawha and enters downstream from the site. According to Barlow (1971), these streams flow in the depression conveniently created by the "old south channel"(Fig. 3). Barlow (1971), proposed that the "old south channel" has since been blocked because one of the streams that drain from the valley wall dumped its bed load in the "old south channel."

Evidence from this study suggests that the site was not an island during the Holocene, but simply a vertically accreting floodplain that eventually developed a levee. For the site to have been an island, the river would have split in an area upstream from the site that is bounded by Wisconsin terraces. The location of these terraces would require the river to split around the upstream end of the island such that the proposed second, now-abandoned channel would have made a nearly right angle bend (Fig. 3). This would give the channel a highly unnatural morphology. Although the island hypothesis cannot be disproved with existing data, most evidence suggests the site was a levee and the proposed "old south channel" (Barlow, 1971) was a slough inundated only by flooding and possibly maintained by tributary stream erosion.

Barlow (1971) and Olafson (1971) theorize that climate in the Kanawha drainage basin is the primary control on the development of the Kanawha low terraces. These authors explain Kanawha terraces formed by adjusting to changes in the climate 
caused by the advance and retreat of glaciers to the north. In these theories, the principal mechanisms for terrace development are the changes in sediment supply and stream flow related to temperature and precipitation within the Kanawha drainage basin in reaction to the global glaciation events.

If the Kanawha River were instead a tributary to a nonglacially influenced trunk, as it is today, then climate local to Kanawha drainage could be a significant control. The opinion that nearby regional glaciation could change the climate of a drainage basin enough to impose a new dictating, geomorphic control should not be denied, but recommended for basins not draining into rivers under such great glacial influence. Under unaltered flow, local climate has probably become a greater geomorphic control on the St. Albans landscape now that the Ohio River is relieved of further glacial influence and made major adjustments to past glacial influence.

Archeological sites have great potential in aiding Quaternary geochronology studies. The fact that ancient peoples inhabited the St. Albans Site accounts for most of the radiocarbon dates obtained from the site. Ancient people built the fires that produced most of the dateable charcoal. Although, archeological sites do not always occur at localities of geologic interest, any new archeological sites occurring in alluvial valleys within the Appalachian Plateaus will add pieces 
to the regional Quaternary puzzle.

The Bartington MS-2F magnetic susceptibility meter appears to be a useful but limited prospecting tool. The tool would probably be of little use in shallow excavations but more valuable when applied to cores at deep sites where excavations can be expensive and dangerous. The tool might also be used in test pits to detect buried soil horizons that might yield artifacts that have accumulated during periods stable to erosion or sedimentation. Although no excavations have been done at the exact location of the cores to investigate the cause of high magnetic susceptibility readings, it appears that at least one test pit feature occurs at the same level that produced high readings in each of two adjacent cores. Because most of the test pits were excavated prior to the magnetic susceptibility reading of the cores, the real success of this instrument as a predictor of occupational layers is still largely untested. If this meter is used as a predevelopment investigative tool at deep stratified sites, excavation time and cost might be saved if productive strata are identified. It is highly suggested that some future St. Albans test pits be located at the exact core locations with the intent to discover if magnetic susceptibility highs are archeologically meaningful and to further test the applicability of the meter.

Cultural fires probably are the main cause of high magnetic 
susceptibility readings at the site but apparently fires are not uniformly distributed over the site. Core drilling can just miss nearby cultural fire hearths and return no signal of occupation. Conversely, wild fires might return magnetic susceptibility highs that are mistaken for cultural signals. Cultures may even have engaged in setting forest fires. The spatial geometry of firecaused magnetic susceptibility highs is poorly understood because evidence comes from cores and excavation faces and not excavation floors. How these highs are affected by weathering, pedogenesis, bioturbation and the reworking by flood waters and foot traffic needs more study. 
Anslinger, C.M., 1998, Research design and management plan for the St. Albans Site (46KA27), Kanawha County, West Virginia, Volume I, Draft, Cultural Resource Analysts, Inc., Hurricane, West Virginia, $327 \mathrm{p}$.

Barlow, James A., 1971, Appendix III - Recent geological history of the St. Albans Site, in Broyles, Bette J., editor, Second preliminary report: the St. Albans Site, Kanawha County, West Virginia: West Virginia Geological and Economic Survey Report of Archeological Investigations Number 3, p. 81-92.

Bell, A. M., 1986, Morphology and stratigraphy of terraces in the upper Shenandoah Valley, Virginia (unpublished M.S. thesis), Morgantown, West Virginia, West Virginia University, 160 p.

Bonnett, R. B., Noltimier, H. C., Sanderson, D. D., A paleomagnetic study of the early Pleistocene Minford Silt Member, Teays Formation, West Virginia: Geological Society of America Special Paper 258, p. 9-18.

Brashler, J. G., S. J. Kite and N. Freidin 1992, 1991 Excavations at the St. Albans Site. Paper presented the 1992 Meetings of the Society for American Archaeology, Pittsburgh.

Brashler, Janet G., Kite, J. Steven, and Friedin, Nicholas J., 1994, Recent research at the St. Albans Site (46KA27), in Proceedings of the "First Discovery of America Conference": Ohio Archaeological Conference, Columbus, Ohio, p. 133-143.

Broyles, Bette J., 1971, Second preliminary report: the St. Albans Site, Kanawha County, West Virginia: West Virginia Geological and Economic Survey Report of Archeological Investigations Number 2, p. 76.

Clark, Anthony, 1990, Seeing beneath the soil, prospecting methods in archaeology: London, B.T. Batsford, Ltd., 168 p.

Doll, Warwick L., Wilmouth, Benton M., and Whetstone, George W., 1960, Water Resources of Kanawha County: U.S. Geological Survey in cooperation with the county court of Kanawha County, West Virginia, $189 \mathrm{p}$.

Dunne, Thomas, and Leopold, Luna B., 1978, Water in environmental planning: San Francisco, W. H. Freeman and Company, 818 p. 
Hand, Robert B., Kerr, Jonathan P., Hughes, Myra A., Niquette, Charles M., 1988, A Phase One Survey and National Register Evaluations of 46PU4 and 46PUSa Winfield Locks and Dam Replacement Project, Putnam County, West Virginia. Cultural Resource Analysts, Inc., Contract Publication Series 88-30, Lexington, Kentucky., 252 p.

Hanson, M.C., 1998, The Teays River: Geofacts, Ohio Department Of Natural Resources, Division of Geological Survey, No. 10, 3 p.

Hemmings, E. T., 1985, West Virginia Radiocarbon Dates and Prehistory: West Virginia Archaeologist, v. 37, no. 2, p. 35-44.

Henderson, Catherine, 1992, Digging for Our Past At Saint Albans, Wonderful West Virginia, v.55, no.11, p. 27-31.

Kite, J. Steven, Rogers, Randal L., and Stuckenrath, Robert, 1990, Cataclysmic Late Wisconsin floods in the upper Ohio River: Geological Society of America Abstracts with Programs (national meeting), v. 22, p. 309.

Kite, J. Steven, 1991 Magnetic Susceptibility at the St. Albans Site, Unpublished notes in possession of the author.

Kite, J. Steven, Nugent C.A., and Lowell T.V., 1993 Magnetic Susceptibility Profiles: A Prospecting Tool for Deep Stratified Archaeological Sites. Paper presented at the 1993 Geological Society of America Meetings, Boston.

Mandel, Rolfe D., 1988, Geomorphology of the Ohio River Valley at the Gallipolis Locks and Dam, West Virginia. Cultural Resource Analysts, Inc., Contract Publication Series 88-38, Lexington, Kentucky, $65 \mathrm{p}$.

Mullins, C.E., 1977, Magnetic susceptibility of the soil and its significance in soil science - a review: on archaeological sites: Journal of Soil Science, v. 28, p.223-246.

Olafson, Sigfus, 1971, Appendix II - Late Pleistocene climate and the St. Albans Site, in Broyles, Bette J., editor, Second preliminary report: the St. Albans Site, Kanawha County, West Virginia: West Virginia Geological and Economic Survey Report of Archeological Investigations Number 3, p. 77-80.

Price, John C., Hunter, Richard G., and McMichael, Edward V., 1964, Core drilling in an archeological site: American Antiquity, v. 30, no. 12, Part 1, p. 219-222.

Rogers, Randal L., Kite, J. Steven, and Stuckenrath, Robert, 
1989, Stratigraphy and geologic history of a low terrace on the Ohio River, Apple Grove, West Virginia: Geological Society of America Abstracts with Programs (national meeting), V. 21, p. 280 .

Rogers, Randal L., 1990, Late Quaternary stratigraphy and geologic history of the upper Ohio River Valley, near Gallipolis Lock and Dam (unpublished M.S. thesis): Morgantown, West Virginia University, $161 \mathrm{p}$.

Schumm, S.A., 1965, Quaternary paleohydrology: The Quaternary of the United States, Wright and Frey, eds., p. 783-794.

Schumm, Stanley A., 1973, Geomorphic thresholds and complex response of drainage systems: in Morisawa, Marie, editor, Fluvial Geomorphology, London, George Allen \& Unwin, p. 299-310.

Soil Survey Division Staff, 1993, Soil Survey Manual, U.S. Department of Agriculture Handbook No. 18, 437 p.

Walker, R.G.. And Cant, D.J., 1984, Sandy fluvial systems: Facies Models, 2nd ed., Kitchener, Ontario, Ainsworth Press Limited, p. $71-90$. 
Textural analysis data for St. Albans

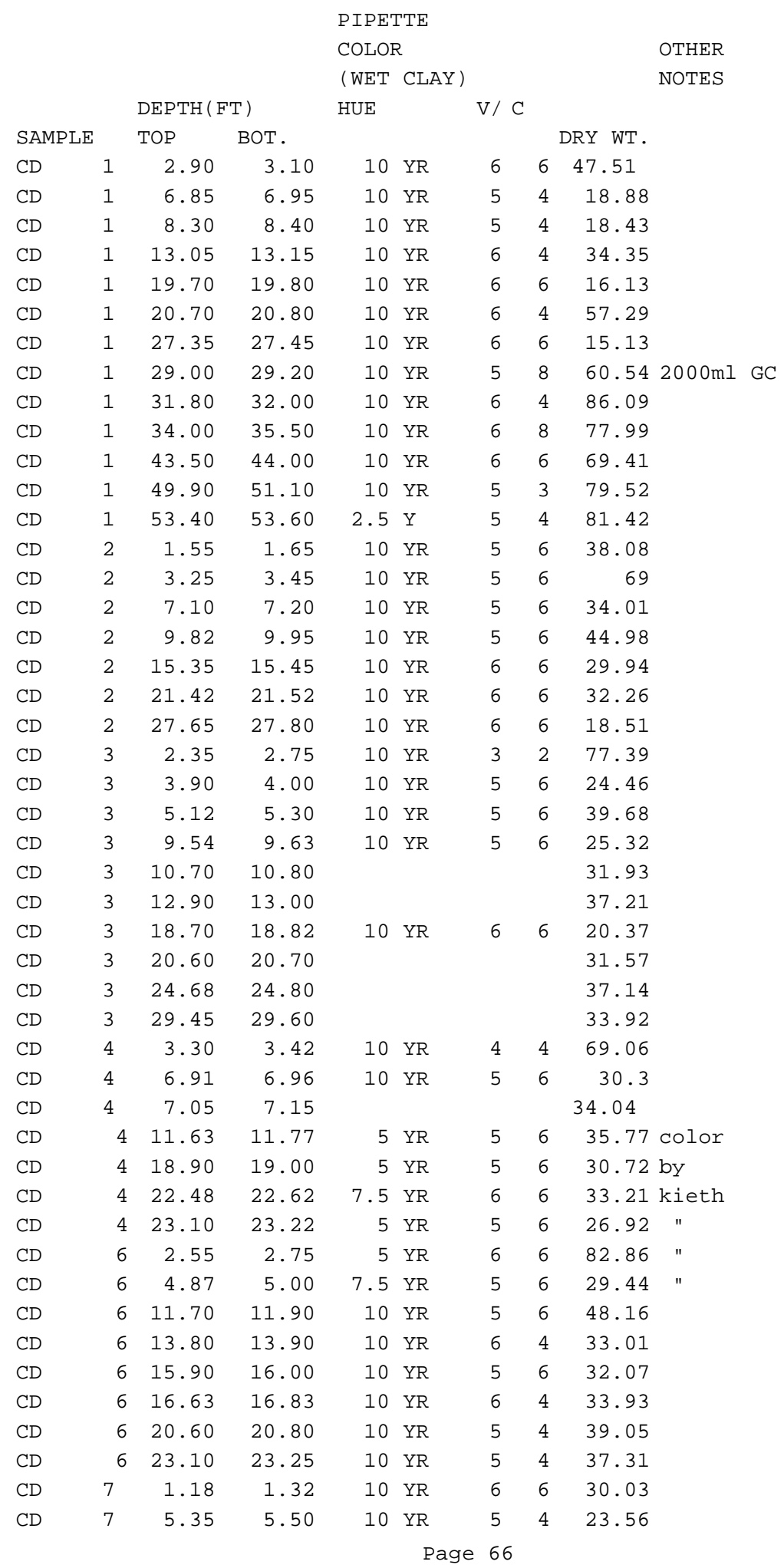




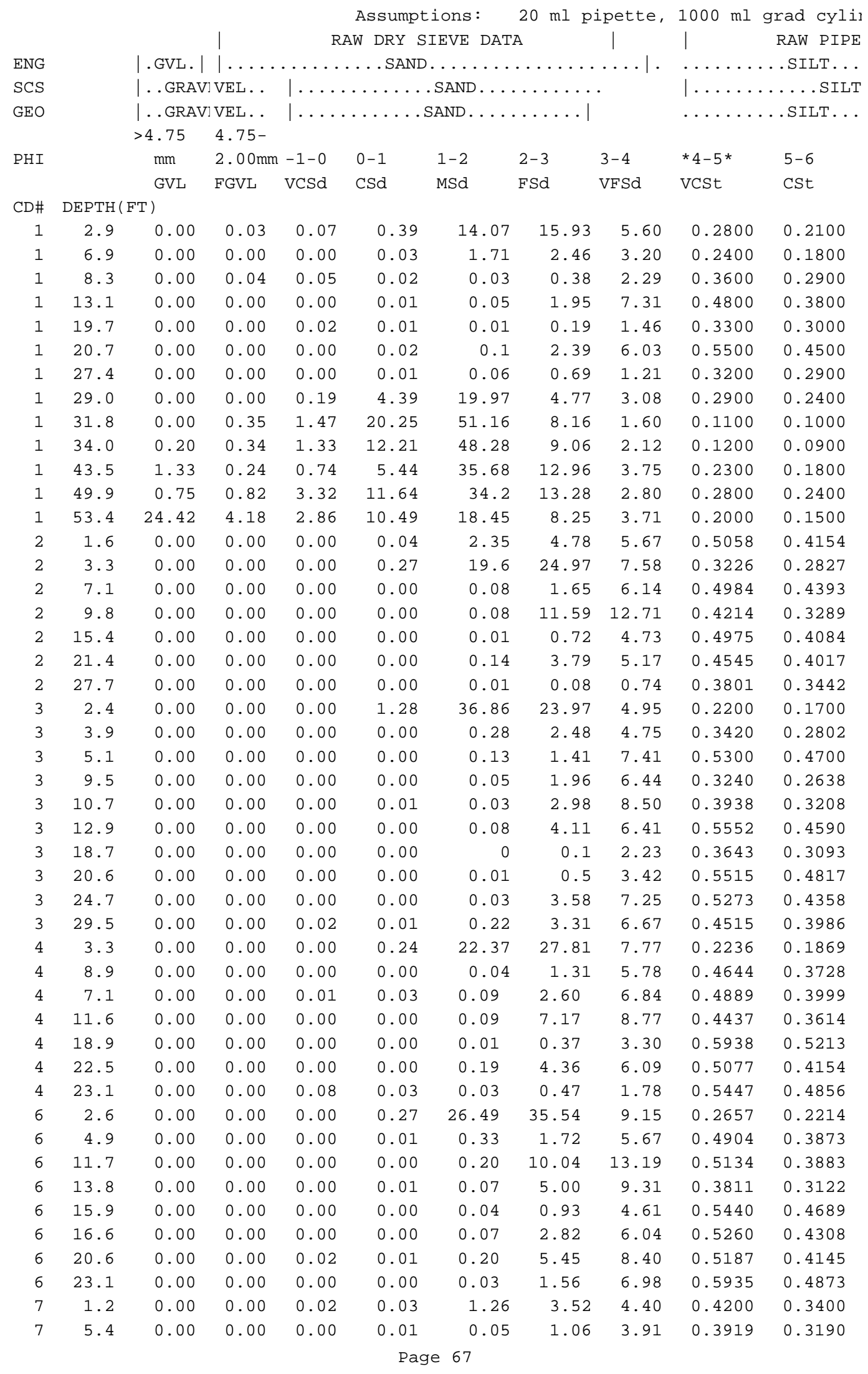




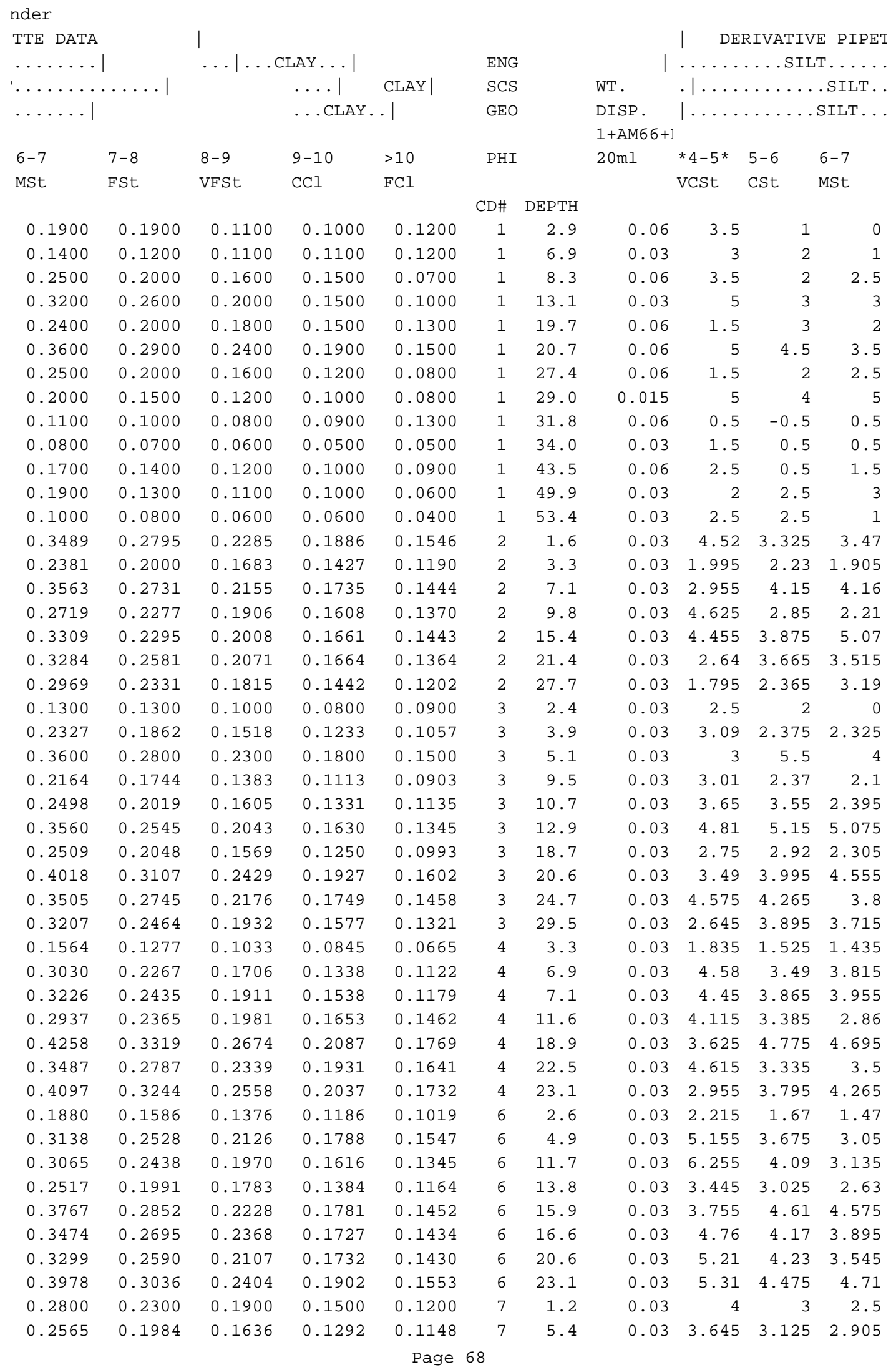


[TE DATA: INTERVAL

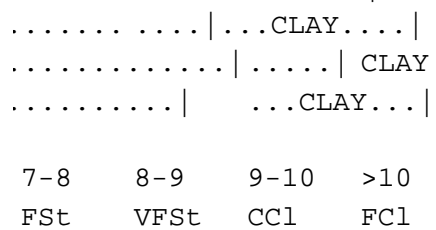

CALCULATED PARTICLE SIZE DISTR] ENG $\mid$. GVL. $\mid \ldots \ldots \ldots \ldots \ldots \ldots \ldots$ SAND $\ldots \ldots \ldots \ldots \ldots \ldots$ SCS $\mid \ldots$. G RAVEL . . $\mid \ldots \ldots \ldots \ldots \ldots$ SAND $\ldots \ldots \ldots \ldots \ldots \ldots$ GEO $\mid \ldots$ G RAVEL . . $\mid \ldots \ldots \ldots \ldots$ SAND . . . . . . . . . . . . \# $>4.75 \quad 4.75-$

PHI $\mathrm{mm} \quad 2.0 \mathrm{~mm} \quad-1-0 \quad 0-1 \quad 1-2 \quad 2-3 \quad 3-4 \quad * 4-5$ * GVL FINEGVL VCSd CSd MSd FSd VFSd VCSt

$\begin{array}{rrrr}4 & 0.5 & -1 & 3 \\ 0.5 & 0 & -0.5 & 4.5 \\ 2 & 0.5 & 4 & 0.5 \\ 3 & 2.5 & 2.5 & 3.5 \\ 1 & 1.5 & 1 & 3.5 \\ 2.5 & 2.5 & 2 & 4.5 \\ 2 & 2 & 2 & 1 \\ 3 & 2 & 2 & 6.5 \\ 1 & -0.5 & -2 & 3.5 \\ 0.5 & 0.5 & 0 & 1 \\ 1 & 1 & 0.5 & 1.5 \\ 1 & 0.5 & 2 & 1.5 \\ 1 & 0 & 1 & 0.5 \\ 2.55 & 1.995 & 1.7 & 6.23 \\ 1.585 & 1.28 & 1.185 & 4.45 \\ 2.88 & 2.1 & 1.455 & 5.72 \\ 1.855 & 1.49 & 1.19 & 5.35 \\ 1.435 & 1.735 & 1.09 & 5.715 \\ 2.55 & 2.035 & 1.5 & 5.32 \\ 2.58 & 1.865 & 1.2 & 4.51 \\ 1.5 & 1 & -0.5 & 3 \\ 1.72 & 1.425 & 0.88 & 3.785 \\ 2.5 & 2.5 & 1.5 & 6 \\ 1.805 & 1.35 & 1.05 & 3.015 \\ 2.07 & 1.37 & 0.98 & 4.175 \\ 2.51 & 2.065 & 1.425 & 5.225 \\ 2.395 & 1.595 & 1.285 & 3.465 \\ 3.39 & 2.51 & 1.625 & 6.51 \\ 2.845 & 2.135 & 1.455 & 5.79 \\ 2.66 & 1.775 & 1.28 & 5.105 \\ 1.22 & 0.94 & 0.9 & 1.825 \\ 2.805 & 1.84 & 1.08 & 4.11 \\ 2.62 & 1.865 & 1.795 & 4.395 \\ 1.92 & 1.64 & 0.955 & 5.81 \\ 3.225 & 2.935 & 1.59 & 7.345 \\ 2.24 & 2.04 & 1.45 & 6.705 \\ 3.43 & 2.605 & 1.525 & 7.16 \\ 1.05 & 0.95 & 0.835 & 3.595 \\ 2.01 & 1.69 & 1.205 & 6.235 \\ 2.34 & 1.77 & 1.355 & 5.225 \\ 1.04 & 1.995 & 1.1 & 4.32 \\ 3.12 & 2.235 & 1.645 & 5.76 \\ 1.635 & 3.205 & 1.465 & 5.67 \\ 2.415 & 1.875 & 1.51 & 5.65 \\ 3.16 & 2.51 & 1.745 & 6.265 \\ 2 & 2 & 1.5 & 4.5 \\ 1.74 & 1.72 & 0.72 & 4.24\end{array}$

$00.0631450 .14730 .820929 .615 \quad 33.5311 .7878 .2509$

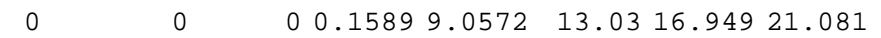
00.2170370 .27130 .10850 .16282 .061912 .42522 .355 $0 \quad 0 \quad 00.02910 .14565 .676921 .28121 .921$ $\begin{array}{llllllll}0 & 0 & 0.124 & 0.062 & 0.062 & 1.1779 & 9.0515 & 15.127\end{array}$ $0 \quad 0 \quad 00.03490 .17464 .171810 .52551 .056$ $\begin{array}{llll}0 & 0 & 0 & 0.06610 .39664 .56057 .997410 .972\end{array}$ $0 \quad 0 \quad 0.31387 .251432 .9867 .87915 .08759 .3162$ 00.4065511 .707523 .52259 .4269 .47851 .85851 .2777 0.25640 .4359531 .705315 .65661 .90511 .6172 .71831 .8592 1.91620 .3457721 .06617 .837551 .40518 .6725 .40274 .7111 $0.94321 .0311874 .1751 \quad 14.63843 .008 \quad 16.73 .52112 .7792$ $29.9935 .1338743 .5127 \quad 12.884 \quad 22.6610 .1334 .55663 .7583$ $\begin{array}{llllllll}0 & 0 & 0 & 0.105 & 6.1712 & 12.553 & 14.89 & 15.678\end{array}$ $\begin{array}{llll}0 & 0 & 0 & 0.391328 .40636 .18810 .9865 .7174\end{array}$ $\begin{array}{lllll}0 & 0 & 0 & 0 & 0.23524 .851518 .05416 .686\end{array}$ $\begin{array}{lllllll}0 & 0 & 0 & 0 & 0.1779 & 25.76728 .257 & 12.572\end{array}$ $\begin{array}{llllllll}0 & 0 & 0 & 0 & 0.0334 & 2.4048 & 15.798 & 18.57\end{array}$ $\begin{array}{llllllll}0 & 0 & 0 & 0 & 0.43411 .748 & 16.02614 .182\end{array}$ $\begin{array}{llllllll}0 & 0 & 0 & 0 & 0.054 & 0.4322 & 3.9978 & 10.643\end{array}$ $\begin{array}{lllll}0 & 0 & 0 & 1.65447 .62930 .9736 .39624 .3029\end{array}$ $\begin{array}{lllllll}0 & 0 & 0 & 0 & 1.144710 .13919 .41918 .152\end{array}$ $\begin{array}{lllll}0 & 0 & 0 & 0 & 0.32763 .553418 .67422 .001\end{array}$ $\begin{array}{lllll}0 & 0 & 0 & 0 & 0.19757 .740925 .43420 .458\end{array}$

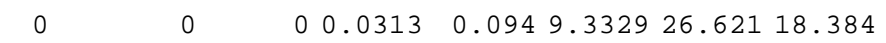

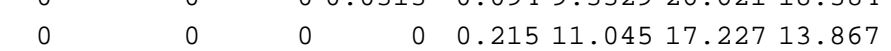
$\begin{array}{rrrrrr}0 & 0 & 0 & 0 & 0 & 0.490910 .94720 .005\end{array}$ $\begin{array}{llllll}0 & 0 & 0 & 0 & 0.03171 .583810 .83316 .012\end{array}$

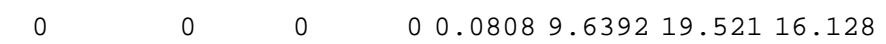
$\begin{array}{llllllll}0 & 0 & 0.059 & 0.0295 & 0.6486 & 9.7583 & 19.66415 .507\end{array}$

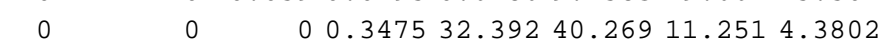
$\begin{array}{llllll}0 & 0 & 0 & 0 & 0.1324 .323419 .076 & 19.901\end{array}$ $\begin{array}{llllllll}0 & 0 & 0.0294 & 0.0881 & 0.2644 & 7.638120 .09417 .553\end{array}$ $\begin{array}{lllll}0 & 0 & 0 & 0 & 0.251620 .04524 .5188 .8622\end{array}$ $0 \quad 0 \quad 0 \quad 00.03261 .204410 .7428 .0566$

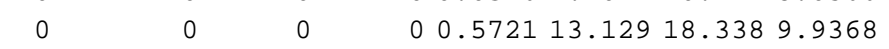
$0 \quad 00.29720 .11140 .11141 .74596 .61226 .5007$ $\begin{array}{llllll}0 & 0 & 0 & 0.3259 & 31.97 & 42.89211 .0432 .2206\end{array}$

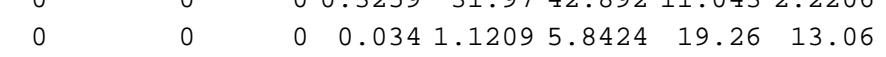
$\begin{array}{lllrllll}0 & 0 & 0 & 0 & 0.4153 & 20.847 & 27.388 & 14.151\end{array}$ $\begin{array}{llllll}0 & 0 & 0 & 0.0303 \quad 0.2121 & 15.14728 .20413 .663\end{array}$ $\begin{array}{llllll}0 & 0 & 0 & 0 & 0.12472 .899914 .37514 .172\end{array}$ $\begin{array}{lllll}0 & 0 & 0 & 0 & 0.20638 .311217 .801 \\ 0 & 0 & 0.0514 .618\end{array}$ $0 \quad 0 \quad 0.05120 .02560 .512213 .95621 .51114 .712$

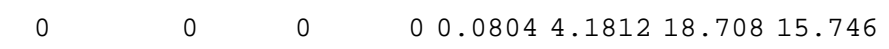
$0 \quad 00.06660 .09994 .195811 .72214 .65217 .649$ $0 \quad 0 \quad 00.0424 \quad 0.21224 .499216 .59617 .317$

Page 69 
IBUTIONS

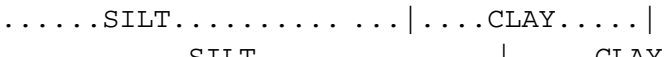

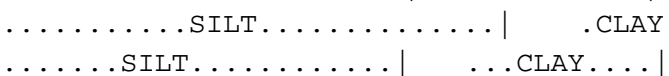

$\begin{array}{cccccc}5-6 & 6-7 & 7-8 & 8-9 & 9-10 & >10\end{array}$

CSt MSt FSt VFSt $\mathrm{CCl}$ FCl

$2.1048 \quad 08.41931 .0524-2.1056 .3145$ $10.5935 .29662 .6483 \quad 0-2.64823 .835$ $\begin{array}{lllllll}10.852 & 13.565 & 10.852 & 2.713 & 21.704 & 2.713\end{array}$ $\begin{array}{llllll}8.7336 & 8.7336 & 8.7336 & 7.278 & 7.278 & 10.189\end{array}$ 18.59912 .3996 .19969 .29946 .199621 .699 $\begin{array}{llllll}7.8548 & 6.1093 & 4.3638 & 4.3638 & 3.491 & 7.8548\end{array}$ 13.21916 .52313 .21913 .21913 .2196 .6094 $6.6072 \quad 8.2594 .95543 .30363 .303610 .737$ $-0.5810 .58081 .1616-0.581-2.3234 .0655$

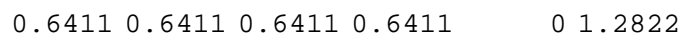
0.72042 .16111 .44071 .44070 .72042 .1611 $3.14393 .7726 \quad 1.2575 \quad 0.62882 .5151 \quad 1.8863$ $3.07051 .22821 .2282 \quad 01.22820 .6141$ $\begin{array}{llllll}8.7316 & 9.1124 & 6.6964 & 5.239 & 4.4643 & 16.36\end{array}$ 3.23192 .76092 .29711 .85511 .71746 .4493 $12.20212 .2328 .46816 .1747 \quad 4.2782 \quad 16.819$ 6.33614 .91334 .12413 .31262 .645611 .894 12.94316 .9344 .79295 .79493 .640619 .088 11.36110 .8967 .90456 .30814 .649716 .491 $\begin{array}{lllllll}12.777 & 17.234 & 13.938 & 10.076 & 6.483 & 24.365\end{array}$ $2.5843 \quad 01.93821 .2922-0.6463 .8765$ $9.70979 .50537 .03195 .82583 .5977 \quad 15.474$ 13.86110 .0816 .30046 .30043 .780215 .121 9.36028 .29387 .12885 .33184 .146911 .908 11.1187 .50086 .48294 .29063 .069213 .075 13.8413 .6396 .74555 .54963 .829614 .042 $14.33511 .31611 .757 \quad 7.83016 .3083 \quad 17.01$ 12.65414 .42810 .7387 .95065 .147320 .621 $\begin{array}{llllll}11.484 & 10.232 & 7.6602 & 5.7485 & 3.9176 & 15.59\end{array}$ $\begin{array}{llllll}11.483 & 10.952 & 7.842 & 5.2329 & 3.7736 & 15.05\end{array}$ 2.20822 .07791 .76661 .36111 .30322 .6426 $11.51812 .5919 .2574 \quad 6.0726 \quad 3.5644 \quad 13.564$ 11.35411 .6197 .69685 .47885 .273212 .911 $9.46327 .99555 .36764 .58482 .6698 \quad 16.243$ $\begin{array}{llllll}15.544 & 15.283 & 10.498 & 9.554 & 5.1758 & 23.91\end{array}$ $\begin{array}{llllll}10.042 & 10.539 & 6.745 & 6.1427 & 4.3662 & 20.19\end{array}$ 14.09715 .84312 .7419 .67685 .664926 .597 2.01541 .77411 .26721 .14651 .00774 .3386 $12.483 \quad 10.36 \quad 6.8274 \quad 5.74054 .093121 .179$ 8.49256 .50964 .85883 .67522 .813510 .849 9.16397 .96733 .15066 .04363 .332313 .087 14.37514 .2669 .72876 .96915 .129417 .961 $12.29 \quad 11.48 \quad 4.81879 .44594 .3177 \quad 16.711$ $10.8329 .07816 .1844 \quad 4.80153 .866814 .469$ $11.99412 .624 \quad 8.4696 \quad 6.7274 \quad 4.677 \quad 16.792$ $\begin{array}{llllll}9.99 & 8.325 & 6.66 & 6.66 & 4.995 & 14.985\end{array}$ $13.264 \quad 12.337 .38547 .3005 \quad 3.05617 .997$

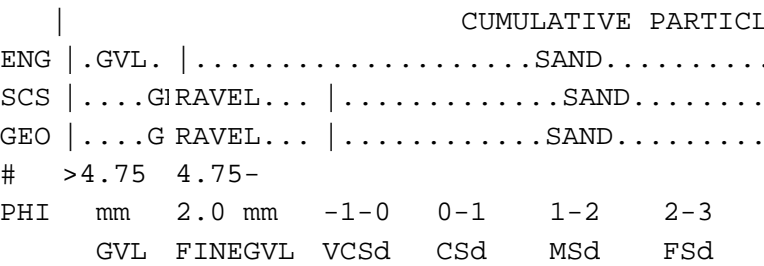

00.0631450 .21051 .031430 .64664 .176

$0 \quad 0 \quad 00.15899 .216122 .246$

$0 \quad 0.2170370 .48830 .59690 .75962 .8215$

$\begin{array}{lllll}0 & 0 & 0 & 0.0291 & 0.17475 .8515\end{array}$

$\begin{array}{lllllll}0 & 0 & 0.124 & 0.186 & 0.248 & 1.4259\end{array}$

$0 \quad 0 \quad 00.03490 .20954 .3812$

$\begin{array}{lllll}0 & 0 & 0 & 0.06610 .46275 .0231\end{array}$

$0 \quad 0 \quad 0.31387 .565240 .55248 .431$

00.4065512 .114125 .63685 .06294 .541

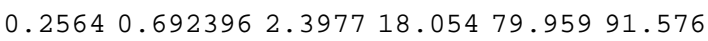
$\begin{array}{llllll}1.9162 & 2.261922 & 3.3281 & 11.166 & 62.57 & 81.242\end{array}$ 0.94321 .9743466 .149420 .78763 .79580 .495 $29.993 \quad 35.126538 .63951 .52374 .18384 .316$

$\begin{array}{llrrrr}0 & 0 & 0 & 0.105 & 6.2763 & 18.829 \\ 0 & 0 & 0 & 0.3913 & 28.797 & 64.986 \\ 0 & 0 & 0 & 0 & 0.2352 & 5.0867 \\ 0 & 0 & 0 & 0 & 0.1779 & 25.945 \\ 0 & 0 & 0 & 0 & 0.0334 & 2.4382 \\ 0 & 0 & 0 & 0 & 0.434 & 12.182 \\ 0 & 0 & 0 & 0 & 0.054 & 0.4862 \\ 0 & 0 & 0 & 1.654 & 49.283 & 80.256 \\ 0 & 0 & 0 & 0 & 1.1447 & 11.284 \\ 0 & 0 & 0 & 0 & 0.3276 & 3.881 \\ 0 & 0 & 0 & 0 & 0.1975 & 7.9384 \\ 0 & 0 & 0 & 0.0313 & 0.1253 & 9.4582 \\ 0 & 0 & 0 & 0 & 0.215 & 11.26 \\ 0 & 0 & 0 & 0 & 0 & 0.4909 \\ 0 & 0 & 0 & 0 & 0.0317 & 1.6155 \\ 0 & 0 & 0 & 0 & 0.0808 & 9.72 \\ 0 & 0 & 0.059 & 0.0884 & 0.737 & 10.495 \\ 0 & 0 & 0 & 0.3475 & 32.74 & 73.009 \\ 0 & 0 & 0 & 0 & 0.132 & 4.4554 \\ 0 & 0 & 0.0294 & 0.1175 & 0.3819 & 8.02 \\ 0 & 0 & 0 & 0 & 0.2516 & 20.296 \\ 0 & 0 & 0 & 0 & 0.0326 & 1.237 \\ 0 & 0 & 0 & 0 & 0.5721 & 13.701 \\ 0 & 0 & 0.2972 & 0.4086 & 0.5201 & 2.266 \\ 0 & 0 & 0 & 0.3259 & 32.295 & 75.187 \\ 0 & 0 & 0 & 0.034 & 1.1549 & 6.9973 \\ 0 & 0 & 0 & 0 & 0.4153 & 21.262 \\ 0 & 0 & 0 & 0.0303 & 0.2424 & 15.389 \\ 0 & 0 & 0 & 0 & 0.1247 & 3.0246 \\ 0 & 0 & 0 & 0 & 0.2063 & 8.5175 \\ 0 & 0 & 0.0512 & 0.0768 & 0.589 & 14.545 \\ 0 & 0 & 0 & 0 & 0.0804 & 4.2616 \\ 0 & 0 & 0.0666 & 0.1665 & 4.3623 & 16.084 \\ 0 & 0 & 0 & 0.0424 & 0.2547 & 4.7538 \\ 0 & & & & & \\ 0 & 0 & 0 & 0\end{array}$




\begin{tabular}{|c|c|c|c|c|c|c|c|c|c|c|}
\hline E SIZE & DISTR & BUT I & & & & | & & & & \\
\hline$\ldots .$. & $\mid \ldots$ & - & SILT. & $\cdots$ & $\cdots$ & . CLA & $\ldots \ldots$ & & & $\frac{\circ}{0}$ \\
\hline$\cdots$ & $\ldots \mid$. & & $\ldots$ & $\mathrm{LT} \ldots$ & $\cdots$ & $\cdots 1$ & . CLAY & & & TOTAL \\
\hline$\ldots \mid$ & $\ldots$. & $\cdots$ & SILT & $\ldots$ & $\ldots \mid$ & $\ldots \mathrm{C}$ & $Y \ldots \mid$ & METH & PIP- & SAMP LE \\
\hline & & & & & & & & $\mathrm{OF}$ & ETTE & LOST \\
\hline $3-4$ & $4-5$ & $5-6$ & $6-7$ & $7-8$ & $8-9$ & $9-10$ & $>10$ & DIFF & & SOME- \\
\hline VFSd & VCSt & CSt & MSt & FSt & VFSt & $\mathrm{CCl}$ & $\mathrm{FCl}$ & VCSt & VCSt & WHERE \\
\hline
\end{tabular}

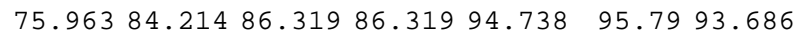
39.19560 .27570 .86976 .16578 .81478 .81476 .165 $\begin{array}{lllllll}15.247 & 37.602 & 48.454 & 62.018 & 72.87 & 75.583 & 97.287\end{array}$ 27.13249 .05457 .78766 .52175 .25582 .53389 .811 10.47725 .60444 .20356 .60362 .80272 .10278 .301 $14.90765 .96373 .81779 .927 \quad 84.2988 .65492 .145$

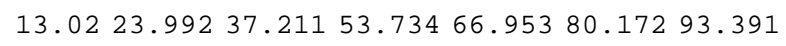

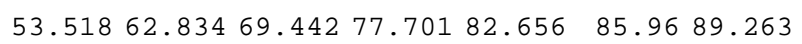
96.39997 .67797 .09697 .67798 .83898 .25895 .934 94.29496 .15396 .79497 .43698 .07798 .71898 .718 86.64591 .35692 .07694 .23795 .67897 .11997 .839

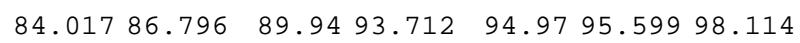

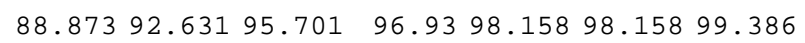

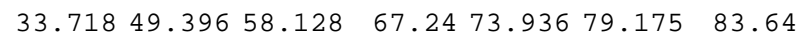

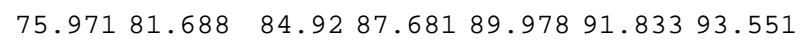
$23.1439 .82752 .02964 .26172 .72978 .903 \quad 83.181$

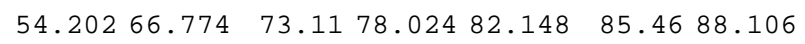
18.23636 .80749 .74966 .68371 .47677 .27180 .912 $28.208 \quad 42.3953 .75164 .64772 .55178 .85983 .509$ 4.484115 .12727 .90445 .13859 .07669 .15275 .635

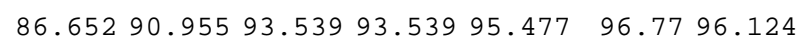
$30.70348 .85558 .565 \quad 68.0775 .10280 .92884 .526$ 22.55544 .55658 .41768 .49874 .79881 .09984 .879 33.37353 .83163 .19171 .48578 .61483 .94588 .092 36.07954 .46365 .58173 .08279 .56583 .85586 .925 $28.48742 .354 \quad 56.195 \quad 69.83376 .57982 .128 \quad 85.958$ $11.43831 .443 \quad 45.778 \quad 57.094 \quad 68.85176 .681 \quad 82.99$ 12.44928 .46141 .11555 .54366 .28174 .23279 .379 $29.24145 .36956 .85267 .08474 .74480 .493 \quad 84.41$ $30.15945 .66657 .14968 .101 \quad 75.94381 .176 \quad 84.95$ $84.26 \quad 88.6490 .84992 .92694 .69396 .05497 .357$ $23.53143 .432 \quad 54.9567 .54176 .79982 .87186 .436$ $28.11445 .66757 .021 \quad 68.6476 .33781 .81687 .089$ $44.81453 .676 \quad 63.1471 .13576 .503 \quad 81.088 \quad 83.757$ $11.97920 .03635 .57950 .86361 .36170 .915 \quad 76.09$ $32.03941 .97552 .01762 .55669 .30175 .444 \quad 79.81$ 8.878215 .37929 .47645 .31958 .06167 .73873 .403

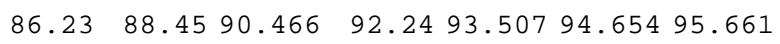

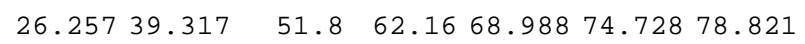
$48.6562 .80171 .29477 .803 \quad 82.66286 .33789 .151$ 43.59357 .25566 .41974 .38777 .53783 .58186 .913

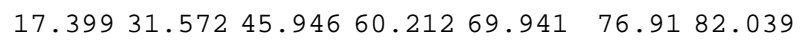
26.31940 .93753 .22764 .70769 .52578 .97183 .289 36.05650 .76861 .60170 .67976 .86381 .66585 .531 $22.9738 .716 \quad 50.7163 .33471 .80478 .53183 .208$

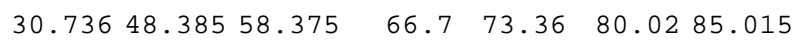
21.3538 .66751 .93164 .26171 .64778 .94782 .003

Page 71
1008.25097 .3669 $10021.081 \quad 15.89$ 10022.35518 .991 10021.92114 .556 10015.1279 .2994 10051.0568 .7275 10010.9729 .9141 $1009.3162 \quad 8.259$ 1001.27770 .5808 1001.85921 .9233 1004.71113 .6018 1002.77922 .5151 1003.75833 .0705 $100 \quad 15.678 \quad 11.87$ 1005.71742 .8913 10016.6868 .6886 $10012.572 \quad 10.282$ $\begin{array}{lll}100 & 18.57 & 14.88\end{array}$ 10014.1828 .1835 10010.6439 .6975 1004.30293 .2304 10018.15212 .633 10022.0017 .5605 10020.45811 .888 10018.38411 .431 $10013.867 \quad 12.927$ $10020.005 \quad 13.5$ 10016.01211 .055 $10016.128 \quad 12.318$ $10015.507 \quad 7.7978$ 1004.38022 .6571 10019.90115 .116 10017.55313 .073 1008.862211 .504 $1008.0566 \quad 11.8$ 1009.936813 .896 1006.500710 .977 1002.22062 .6732 $\begin{array}{lll}100 & 13.06 & 17.51\end{array}$ $10014.151 \quad 12.988$ 10013.66310 .436 10014.17211 .709 10014.61814 .029 10014.71213 .342 10015.74614 .232 $10017.649 \quad 13.32$ 10017.31715 .471
0.9 5.2 3.4 7.4 5.8 42.3 1.1 1.1 0.7 $-0.1$ 1.1 0.3 0.7 3.8 2.8 8.0 2.3 3.7 6.0 0.9 1.1 5.5

14.4 8.6 7.0 0.9 6.5 5.0 3.8 7.7 1.7 4.8 4.5 $-2.6$ $-3.7$ $-4.0$ $-4.5$ $-0.5$ $-4.4$ 1.2 3.2 2.5 0.6 1.4 1.5 4.3 1.8 


\begin{tabular}{|c|c|c|c|c|c|c|c|c|c|c|}
\hline ENGINEE & ING $S$ & $\mathrm{ZE} \mathrm{BF}$ & AKS & GEOLOC & Y SIZF & BREA & & GEOL & SIZE $B$ & AKS \\
\hline GRAVEI & SAND & SILT & CLAY & GRAVEL & SAND & SILT & CLAY & SAND & SILT & CLAY \\
\hline
\end{tabular}

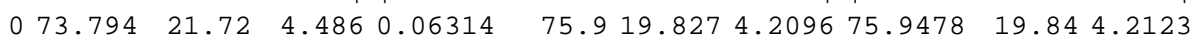
$036.07642 .73721 .186 \quad 039.19539 .61921 .18639 .194939 .61921 .186$

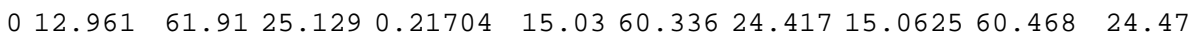
$\begin{array}{lllllll}023.21757 .405 & 19.379 & 0 & 27.132 & 55.417 .467 & 27.1325 & 55.417 .467\end{array}$ $08.811960 .84730 .341 \quad 010.47761 .62427 .89810 .477461 .62427 .898$ $0 \quad 12.9774 .53812 .492 \quad 014.90773 .74811 .34614 .906673 .74811 .346$

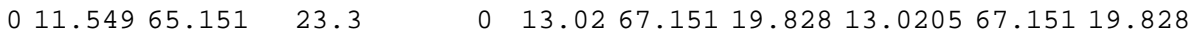

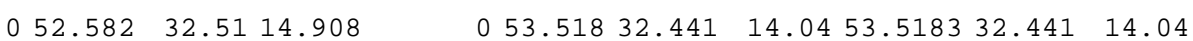

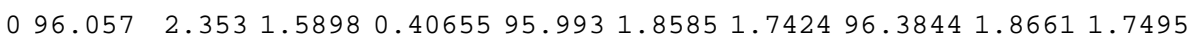
$0.2564493 .5384 .75541 .4506 \quad 0.692493 .6024 .42361 .282294 .25444 .45451 .2912$ $1.9161583 .734 \quad 11.093 .25982 .2619284 .38310 .4742 .881486 .335510 .7162 .9481$ 0.9431682 .42612 .0654 .56651 .9743582 .04211 .5824 .401483 .694711 .8154 .4901 29.992658 .04110 .1241 .842335 .126553 .7469 .28521 .842382 .847414 .3132 .8398 $\begin{array}{lllll}030.979 & 46.821 & 22.2 & 0 & 33.71845 .45720 .82533 .718545 .45720 .825\end{array}$ $0 \quad 73.9517 .3968 .6539$ 019.81857 .46322 .718 $049.00335 .588 \quad 15.41$ $0 \quad 15.33 \quad 60.42 \quad 24.251$ $0 \quad 25.2651 .94322 .797$ 03.748562 .75733 .494 085.47510 .9553 .5697 $0 \quad 27.1352 .26820 .602$ 019.11960 .32520 .556 028.69353 .85217 .455 031.18151 .54817 .272 025.31755 .35419 .329 09.424165 .20125 .375 010.45561 .68927 .856 025.64953 .33421 .017 026.54153 .26120 .198 $0 \quad 82.1913 .507 \quad 4.3033$ 020.02161 .25518 .724 $024.417 \quad 55.9619 .623$ 040.30339 .58120 .117 010.00358 .40331 .594 028.66445 .16726 .169 07.661557 .53534 .804 $084.19810 .155 \quad 5.6475$ 022.71350 .50826 .779 043.61141 .76114 .628 $038.403 \quad 43.5918 .006$ $\begin{array}{llll}0 & 14.754 & 60.325 & 24.92\end{array}$ 023.04353 .44723 .509 032.09848 .30519 .596 019.52757 .23723 .236 $0 \quad 28.0450 .23121 .729$ $0 \quad 18.29658 .734 \quad 22.97$ $\begin{array}{lllllll}0 & 75.971 & 15.862 & 8.1667 & 75.971 & 15.862 & 8.1667\end{array}$ $0 \quad 23.1455 .76321 .09723 .140355 .76321 .097$ $\begin{array}{lllllll}0 & 54.202 & 31.258 & 14.54 & 54.2019 & 31.258 & 14.54\end{array}$ 018.23659 .03522 .72918 .236559 .03522 .729 028.20850 .65121 .14128 .208350 .65121 .141 04.484164 .66830 .8484 .4840664 .66830 .848

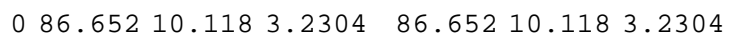
030.70350 .22519 .07230 .703250 .22519 .072 022.55558 .54318 .90122 .555458 .54318 .901 033.37350 .57316 .05533 .372850 .57316 .055 036.07947 .77616 .14536 .078947 .77616 .145

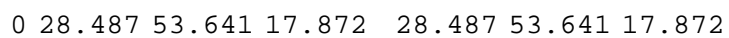
011.43865 .24323 .31911 .438465 .24323 .319 $012.44961 .78325 .76812 .448561 .783 \quad 25.768$ 029.24151 .25219 .50729 .240751 .25219 .507 $030.15951 .01718 .82430 .159251 .017 \quad 18.824$ $0 \quad 84.2611 .7943 .9458 \quad 84.2601 \quad 11.7943 .9458$ $\begin{array}{lllllll}0 & 23.531 & 59.34 & 17.129 & 23.5314 & 59.34 & 17.129\end{array}$ $\begin{array}{lllllll}0 & 28.114 & 53.702 & 18.184 & 28.114 & 53.702 & 18.184\end{array}$ $044.81436 .273 \quad 18.91244 .814136 .27318 .912$ 011.97958 .93629 .08511 .979258 .93629 .085 032.03943 .40624 .55632 .038543 .40624 .556

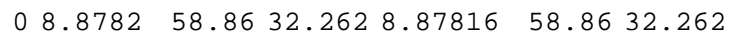

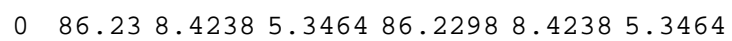
$\begin{array}{llllll}0 & 26.25748 .47125 .272 & 26.2568 & 48.471 & 25.272\end{array}$

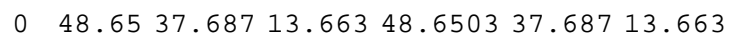
043.59339 .98816 .41943 .592939 .98816 .419 $\begin{array}{lllllll}0 & 17.399 & 59.51 & 23.09 & 17.3994 & 59.51 & 23.09\end{array}$ 026.31952 .65321 .02926 .318952 .65321 .029 036.05645 .60818 .33536 .056345 .60818 .335 $0 \quad 22.9755 .56221 .46922 .969755 .56221 .469$ $\begin{array}{lllllll}0 & 30.736 & 49.284 & 19.98 & 30.7359 & 49.284 & 19.98\end{array}$ $0 \quad 21.3557 .59821 .05321 .349757 .59821 .053$ Page 72 
MAJOR SIZE CLASSES

EXCLUDING GRAVEL

\begin{tabular}{|c|c|c|c|c|c|c|c|}
\hline \multicolumn{3}{|c|}{ USDA-SCS SIZES } & \multicolumn{5}{|l|}{ SCS } \\
\hline SAND & SILT & CLAY & SIZE & CLASS & $\mathrm{CD} \#$ & DEP & \\
\hline | & & | & & & & ft & meters \\
\hline 79.1437 & 14.538 & 6.3184 & LOAMY & Y SAND & 1 & 2.90 & 0.884 \\
\hline 47.3551 & 28.81 & 23.835 & LOAM & & 1 & 6.85 & 2.088 \\
\hline 23.7348 & 73.546 & 2.7189 & SILT & LOAM & 1 & 8.30 & 2.53 \\
\hline 35.6182 & 54.193 & 10.189 & SILT & LOAM & 1 & 13.05 & 3.978 \\
\hline 16.333 & 61.968 & 21.699 & SILT & LOAM & 1 & 19.70 & 6.005 \\
\hline 34.6702 & 57.475 & 7.8548 & SILT & LOAM & 1 & 20.70 & 6.309 \\
\hline 17.2676 & 76.123 & 6.6094 & SILT & LOAM & 1 & 27.35 & 8.336 \\
\hline 57.1246 & 32.139 & 10.737 & SANDY & Y LOAM & 1 & 29.00 & 8.839 \\
\hline 96.881 & -0.963 & 4.0821 & SAND & & 1 & 31.80 & 9.693 \\
\hline 94.9791 & 3.7298 & 1.2912 & SAND & & 1 & 34.00 & 10.36 \\
\hline 88.2014 & 9.5875 & 2.2111 & SAND & & 1 & 43.50 & 13.26 \\
\hline 84.7922 & 13.284 & 1.9243 & LOAMY & Y SAND & 1 & 49.90 & 15.21 \\
\hline 85.09 & 13.963 & 0.9466 & GRAVE & ELY SAND & 1 & 53.40 & 16.28 \\
\hline 39.7872 & 43.853 & 16.36 & LOAM & & 2 & 1.55 & 0.472 \\
\hline 78.1842 & 15.367 & 6.4493 & LOAMY & Y SAND & 2 & 3.25 & 0.991 \\
\hline 29.5995 & 53.582 & 16.819 & SILT & LOAM & 2 & 7.10 & 2.164 \\
\hline 59.0685 & 29.037 & 11.894 & SANDY & Y LOAM & 2 & 9.82 & 2.993 \\
\hline 25.425 & 55.487 & 19.088 & SILT & LOAM & 2 & 15.35 & 4.679 \\
\hline 33.698 & 49.811 & 16.491 & LOAM & & 2 & 21.42 & 6.529 \\
\hline 8.60389 & 67.031 & 24.365 & SILT & LOAM & 2 & 27.65 & 8.428 \\
\hline 88.3177 & 7.8059 & 3.8765 & SAND & & 3 & 2.35 & 0.716 \\
\hline 37.7298 & 46.796 & 15.474 & LOAM & & 3 & 3.90 & 1.189 \\
\hline 31.072 & 53.807 & 15.121 & SILT & LOAM & 3 & 5.12 & 1.561 \\
\hline 41.2921 & 46.8 & 11.908 & LOAM & & 3 & 9.54 & 2.908 \\
\hline 43.1953 & 43.729 & 13.075 & LOAM & & 3 & 10.70 & 3.261 \\
\hline 33.8549 & 52.103 & 14.042 & SILT & LOAM & 3 & 12.90 & 3.932 \\
\hline 19.1822 & 63.807 & 17.01 & SILT & LOAM & 3 & 18.70 & 5.7 \\
\hline 18.6467 & 60.732 & 20.621 & SILT & LOAM & 3 & 20.60 & 6.279 \\
\hline 35.4839 & 48.926 & 15.59 & LOAM & & 3 & 24.68 & 7.522 \\
\hline 36.1619 & 48.788 & 15.05 & LOAM & & 3 & 29.45 & 8.976 \\
\hline 85.9556 & 11.402 & 2.6426 & SAND & & 4 & 3.30 & 1.006 \\
\hline 31.235 & 55.201 & 13.564 & SILT & LOAM & 4 & 6.91 & 2.106 \\
\hline 34.9086 & 52.18 & 12.911 & SILT & LOAM & 4 & 7.05 & 2.149 \\
\hline 48.2446 & 35.513 & 16.243 & LOAM & & 4 & 11.63 & 3.545 \\
\hline 15.0979 & 60.993 & 23.91 & SILT & LOAM & 4 & 18.90 & 5.761 \\
\hline 35.885 & 43.925 & 20.19 & LOAM & & 4 & 22.48 & 6.852 \\
\hline 11.3946 & 62.008 & 26.597 & SILT & LOAM & 4 & 23.10 & 7.041 \\
\hline 87.0894 & 8.572 & 4.3386 & SAND & & 6 & 2.55 & 0.777 \\
\hline 31.3125 & 47.509 & 21.179 & LOAM & & 6 & 4.87 & 1.484 \\
\hline 54.128 & 35.023 & 10.849 & SANDY & Y LOAM & 6 & 11.70 & 3.566 \\
\hline 48.8816 & 38.031 & 13.087 & LOAM & & 6 & 13.80 & 4.206 \\
\hline 22.8854 & 59.154 & 17.961 & SILT & LOAM & 6 & 15.90 & 4.846 \\
\hline 31.9776 & 51.312 & 16.711 & SILT & LOAM & 6 & 16.63 & 5.069 \\
\hline 41.7513 & 43.78 & 14.469 & LOAM & & 6 & 20.60 & 6.279 \\
\hline 29.0651 & 54.143 & 16.792 & SILT & LOAM & 6 & 23.10 & 7.041 \\
\hline 37.5678 & 47.447 & 14.985 & LOAM & & 7 & 1.18 & 0.36 \\
\hline 28.0533 & 53.95 & 17.997 & SILT & LOAM & 7 & 5.35 & 1.631 \\
\hline
\end{tabular}




\begin{tabular}{|c|c|c|c|c|c|c|c|c|}
\hline CD & 7 & 8.47 & 8.65 & 10 & YR & 5 & 4 & 47.56 \\
\hline $\mathrm{CD}$ & 7 & 10.25 & 10.40 & 10 & YR & 6 & 6 & $69.82000 \mathrm{ml} \mathrm{GC}$ \\
\hline$C D$ & 7 & 12.60 & 12.77 & 10 & YR & 5 & 4 & 27.06 \\
\hline$C D$ & 7 & 19.33 & 19.47 & 10 & YR & 6 & 6 & 35.98 \\
\hline$C D$ & 7 & 21.12 & 21.28 & 10 & YR & 6 & 6 & 27.21 \\
\hline CD & 7 & 22.84 & 22.98 & 10 & YR & 6 & 6 & 33.79 \\
\hline$C D$ & 7 & 24.35 & 24.45 & 10 & YR & 6 & 6 & 25.9 \\
\hline CD & 7 & 27.55 & 27.80 & 10 & YR & 6 & 6 & 98.11 \\
\hline $\mathrm{CD}$ & 8 & 2.82 & 3.08 & 10 & YR & 3 & 2 & 78.45 \\
\hline$C D$ & 8 & 6.80 & & 10 & YR & 5 & 4 & 35.6 \\
\hline$C D$ & 8 & 11.10 & & 10 & YR & 5 & 4 & 38.16 \\
\hline$C D$ & 8 & 15.07 & 15.30 & 10 & YR & 5 & 4 & 38.06 \\
\hline $\mathrm{CD}$ & 8 & 21.10 & & 10 & YR & 5 & 4 & 27.43 \\
\hline$C D$ & 8 & 23.60 & & 10 & YR & 5 & 4 & 38.84 \\
\hline $\mathrm{CD}$ & 9 & 1.50 & & 10 & YR & 5 & 4 & 27 \\
\hline CD & 9 & 3.20 & & 10 & YR & 5 & 4 & 44.38 \\
\hline CD & 9 & 5.90 & & 10 & YR & 5 & 4 & 37.53 \\
\hline CD & 9 & 9.38 & 9.50 & 10 & YR & 5 & 6 & 58.48 \\
\hline $\mathrm{CD}$ & 9 & 12.90 & 13.20 & 10 & YR & 5 & 6 & 55.58 \\
\hline $\mathrm{CD}$ & 9 & 13.10 & & 10 & YR & 5 & 4 & 38.79 \\
\hline CD & 9 & 23.20 & & 10 & YR & 5 & 4 & 39.8 \\
\hline $\mathrm{CD}$ & 9 & 27.08 & 27.2 & 10 & YR & 6 & 6 & 30.73 \\
\hline $\mathrm{CD}$ & 9 & 31.20 & 31.35 & 10 & $\mathrm{YR}$ & 6 & 6 & 88.34 \\
\hline CD & 10 & 1.30 & & 10 & YR & 4 & 3 & 48.82 \\
\hline $\mathrm{CD}$ & 10 & 6.40 & & 10 & YR & 5 & 4 & 43.37 \\
\hline $\mathrm{CD}$ & 10 & 13.15 & & 10 & YR & 5 & 4 & 27.1 \\
\hline CD & 10 & 16.38 & & 10 & YR & 5 & 4 & 30.39 \\
\hline $\mathrm{CD}$ & 10 & 17.25 & & 10 & YR & 5 & 4 & 53.01 \\
\hline $\mathrm{CD}$ & 10 & 18.80 & & 10 & $\mathrm{YR}$ & 5 & 6 & 27.8 \\
\hline$C D$ & 10 & 19.70 & & 10 & YR & 5 & 4 & 41.65 \\
\hline CD & 10 & 20.80 & & 10 & YR & 5 & 6 & 24.08 \\
\hline $\mathrm{CD}$ & 10 & 24.10 & & 10 & YR & & & 29.99 \\
\hline $\mathrm{CD}$ & 11 & 3.90 & & 10 & YR & 4 & 4 & 72.39 \\
\hline $\mathrm{CD}$ & 11 & 7.30 & & 10 & YR & 5 & 4 & 38.14 \\
\hline $\mathrm{CD}$ & 11 & 8.85 & & 10 & YR & 5 & 4 & 50.48 \\
\hline $\mathrm{CD}$ & 11 & 10.60 & & 10 & YR & 5 & 4 & 37.88 \\
\hline $\mathrm{CD}$ & 11 & 16.50 & & 10 & YR & 5 & 4 & 45.59 \\
\hline CD & 11 & 20.80 & & 10 & YR & 5 & 4 & 41.63 \\
\hline CD & 11 & 25.35 & & 10 & $\mathrm{YR}$ & 5 & 4 & 35.28 \\
\hline $\mathrm{CD}$ & 11 & 27.55 & & 10 & YR & 5 & 4 & 35.89 \\
\hline $\mathrm{CD}$ & 12 & 0.60 & & 10 & YR & 5 & 3 & $34.052000 \mathrm{ml} \mathrm{GC}$ \\
\hline CD & 12 & 3.40 & & 10 & $\mathrm{YR}$ & 7 & 4 & 41.07 \\
\hline CD & 12 & 9.55 & & 10 & YR & 5 & 4 & 30.89 \\
\hline $\mathrm{CD}$ & 12 & 11.45 & & 10 & YR & 6 & 4 & 38.36 \\
\hline CD & 12 & 15.30 & & 10 & $\mathrm{YR}$ & 6 & 6 & 37.01 \\
\hline $\mathrm{CD}$ & 12 & 21.40 & & 10 & YR & 6 & 6 & 60.79 \\
\hline $\mathrm{CD}$ & 12 & 24.55 & & 10 & YR & 6 & 3 & 48.86 \\
\hline CD & 12 & 25.80 & & 10 & $\mathrm{YR}$ & 4 & 3 & 81.87 \\
\hline CD & 13 & 4.65 & & 10 & YR & 6 & 4 & 36.37 \\
\hline CD & 13 & 8.60 & & 10 & YR & 5 & 6 & 34.02 \\
\hline CD & 13 & 13.40 & & 10 & $\mathrm{YR}$ & 5 & 4 & 40.37 \\
\hline CD & 13 & 15.80 & & 10 & YR & 5 & 6 & 45.29 \\
\hline $\mathrm{CD}$ & 13 & 19.15 & & 10 & YR & 5 & 4 & 50.37 \\
\hline CD & 13 & 21.55 & & 10 & YR & 5 & 4 & 66.78 \\
\hline CD & 13 & 21.80 & & 10 & YR & 5 & 6 & 29.97 \\
\hline \multirow[t]{2}{*}{$C D$} & 13 & 24.80 & & 10 & YR & 6 & 6 & 33.15 \\
\hline & & & & & $\mathrm{Pa}$ & 74 & & \\
\hline
\end{tabular}




\begin{tabular}{|c|c|c|c|c|c|c|c|c|c|}
\hline 8.5 & 0.00 & 0.00 & 0.00 & 0.01 & 5.03 & 18.47 & 6.66 & 0.3664 & 0.3027 \\
\hline 10.3 & 0.00 & 0.00 & 0.00 & 0.03 & 5.09 & 20.91 & 11.11 & 0.3000 & 0.2500 \\
\hline 12.6 & 0.00 & 0.00 & 0.02 & 0.08 & 0.07 & 3 & 6.95 & 0.3581 & 0.2924 \\
\hline 19.3 & 0.00 & 0.00 & 0.00 & 0.01 & 0.12 & 3.39 & 7.34 & 0.5232 & 0.4243 \\
\hline 21.1 & 0.00 & 0.00 & 0.00 & 0.00 & 0.01 & 1.05 & 4.82 & 0.4300 & 0.3700 \\
\hline 22.8 & 0.00 & 0.00 & 0.01 & 0.01 & 0.08 & 5.44 & 6.53 & 0.4400 & 0.3600 \\
\hline 24.4 & 0.00 & 0.00 & 0.00 & 0.00 & 0.02 & 0.33 & 2.03 & 0.4900 & 0.4200 \\
\hline 27.6 & 0.00 & 0.04 & 0.46 & 10.18 & 64.39 & 13.13 & 2.02 & 0.1800 & 0.1600 \\
\hline 2.8 & 0.00 & 0.00 & 0.00 & 0.74 & 38.04 & 28.12 & 4.62 & 0.1659 & 0.1361 \\
\hline 6.8 & 0.00 & 0.00 & 0.00 & 0.01 & 0.72 & 2.6 & 7.15 & 0.5204 & 0.4180 \\
\hline 11.1 & 0.00 & 0.00 & 0.00 & 0.00 & 0.08 & 3.84 & 8.83 & 0.5471 & 0.4269 \\
\hline 15.1 & 0.00 & 0.00 & 0.00 & 0.00 & 0.11 & 4.66 & 9.27 & 0.5055 & 0.4119 \\
\hline 21.1 & 0.00 & 0.00 & 0.00 & 0.00 & 0.11 & 1.15 & 2.15 & 0.5017 & 0.4335 \\
\hline 23.6 & 0.00 & 0.00 & 0.00 & 0.00 & 0.08 & 5.45 & 9.01 & 0.5041 & 0.3969 \\
\hline 1.5 & 0.00 & 0.00 & 0.00 & 0.02 & 0.83 & 2.73 & 4.91 & 0.4058 & 0.3220 \\
\hline 3.2 & 0.00 & 0.00 & 0.00 & 0.00 & 0.64 & 6.5 & 10.88 & 0.5473 & 0.4248 \\
\hline 5.9 & 0.00 & 0.00 & 0.00 & 0.00 & 0.15 & 3 & 8.50 & 0.5409 & 0.4263 \\
\hline 9.4 & 0.00 & 0.00 & 0.02 & 0.03 & 0.38 & 11.13 & 15.54 & 0.6100 & 0.4400 \\
\hline 12.9 & 0.00 & 0.00 & 0.00 & 0.01 & 0.19 & 11.07 & 15.71 & 0.5400 & 0.4300 \\
\hline 13.1 & 0.00 & 0.00 & 0.00 & 0.00 & 0.1 & 2.32 & 6.09 & 0.6297 & 0.5323 \\
\hline 23.2 & 0.00 & 0.00 & 0.00 & 0.00 & 0.17 & 6.9 & 9.61 & 0.4691 & 0.3833 \\
\hline 27.1 & 0.00 & 0.00 & 0.00 & 0.00 & 0.13 & 2.26 & 3.65 & 0.5009 & 0.4280 \\
\hline 31.2 & 0.00 & 0.11 & 0.52 & 12.20 & 53.42 & 15.57 & 2.03 & 0.1100 & 0.0900 \\
\hline 1.3 & 0.00 & 0.00 & 0.00 & 0.02 & 2.34 & 13.12 & 11.22 & 0.4496 & 0.3630 \\
\hline 6.4 & 0.00 & 0.00 & 0.00 & 0.00 & 0.74 & 6.54 & 9.66 & 0.5394 & 0.4440 \\
\hline 13.2 & 0.00 & 0.00 & 0.00 & 0.00 & 0.07 & 1.01 & 2.90 & 0.4931 & 0.4201 \\
\hline 16.4 & 0.00 & 0.00 & 0.00 & 0.00 & 0.05 & 1.92 & 3.06 & 0.5299 & 0.4718 \\
\hline 17.3 & 0.00 & 0.00 & 0.00 & 0.01 & 4.97 & 26.41 & 4.88 & 0.3692 & 0.3227 \\
\hline 18.8 & 0.00 & 0.00 & 0.00 & 0.01 & 0.03 & 0.67 & 2.40 & 0.5255 & 0.4561 \\
\hline 19.7 & 0.00 & 0.00 & 0.00 & 0.02 & 3.43 & 16.62 & 7.01 & 0.3154 & 0.2563 \\
\hline 20.8 & 0.00 & 0.00 & 0.00 & 0.00 & 0.04 & 0.5 & 1.25 & 0.4683 & 0.4247 \\
\hline 24.1 & 0.00 & 0.00 & 0.00 & 0.00 & 0.14 & 1.41 & 3.81 & 0.5211 & 0.4346 \\
\hline 3.9 & 0.00 & 0.00 & 0.00 & 1.82 & 37.87 & 20.22 & 4.10 & 0.1905 & 0.1606 \\
\hline 7.3 & 0.00 & 0.00 & 0.00 & 0.02 & 0.56 & 4.7 & 10.15 & 0.4813 & 0.3675 \\
\hline 8.9 & 0.00 & 0.00 & 0.00 & 0.06 & 2.84 & 7.2 & 10.24 & 0.6336 & 0.4967 \\
\hline 10.6 & 0.00 & 0.00 & 0.00 & 0.00 & 0.06 & 4.49 & 9.04 & 0.5016 & 0.3965 \\
\hline 16.5 & 0.00 & 0.00 & 0.00 & 0.00 & 0.57 & 10.99 & 11.53 & 0.4736 & 0.3797 \\
\hline 20.8 & 0.00 & 0.00 & 0.00 & 0.00 & 0.06 & 1.71 & 4.78 & 0.7060 & 0.6012 \\
\hline 25.4 & 0.00 & 0.00 & 0.00 & 0.00 & 0.06 & 2.51 & 7.15 & 0.5132 & 0.4366 \\
\hline 27.6 & 0.00 & 0.00 & 0.00 & 0.00 & 0.02 & 0.77 & 2.91 & 0.6551 & 0.5886 \\
\hline 0.6 & 1.83 & 1.37 & 0.39 & 0.38 & 0.69 & 0.94 & 1.69 & 0.2756 & 0.2420 \\
\hline 3.4 & 0.00 & 0.00 & 0.13 & 0.42 & 0.2 & 0.45 & 1.56 & 0.7751 & 0.7293 \\
\hline 9.6 & 0.00 & 0.08 & 0.16 & 0.11 & 0.1 & 0.21 & 0.91 & 0.6143 & 0.5747 \\
\hline 11.5 & 0.00 & 0.03 & 0.35 & 0.36 & 0.31 & 0.72 & 1.17 & 0.7289 & 0.6917 \\
\hline 15.3 & 0.00 & 0.00 & 0.00 & 0.02 & 0.04 & 0.58 & 3.99 & 0.6662 & 0.5790 \\
\hline 21.4 & 0.00 & 0.00 & 0.00 & 0.00 & 3.48 & 25.17 & 11.86 & 0.4245 & 0.3368 \\
\hline 24.6 & 0.00 & 0.00 & 0.00 & 0.00 & 0.03 & 0.31 & 2.82 & 0.9221 & 0.7829 \\
\hline 25.8 & 0.00 & 0.07 & 0.40 & 6.92 & 40.77 & 18.21 & 5.55 & 0.2270 & 0.1794 \\
\hline 4.7 & 0.00 & 0.00 & 0.00 & 0.00 & 1.05 & 9.71 & 8.46 & 0.3470 & 0.2818 \\
\hline 8.6 & 0.00 & 0.00 & 0.00 & 0.00 & 0.01 & 1.54 & 5.43 & 0.5526 & 0.4631 \\
\hline 13.4 & 0.00 & 0.17 & 0.00 & 0.00 & 0.04 & 2.58 & 6.59 & 0.6562 & 0.5236 \\
\hline 15.8 & 0.00 & 0.00 & 0.00 & 0.00 & 0.1 & 7.09 & 12.01 & 0.5453 & 0.4338 \\
\hline 19.2 & 0.00 & 0.00 & 0.00 & 0.00 & 0.01 & 0.53 & 3.61 & 0.9425 & 0.8401 \\
\hline 21.6 & 0.00 & 0.00 & 0.00 & 0.02 & 1.87 & 29.67 & 7.90 & 0.5645 & 0.4930 \\
\hline 21.8 & 0.00 & 0.00 & 0.00 & 0.00 & 0.07 & 2.42 & 1.56 & 0.5127 & 0.4776 \\
\hline 24.8 & 0.00 & 0.00 & 0.00 & 0.00 & 0.02 & 0.9 & 3.19 & 0.5716 & 0.5320 \\
\hline
\end{tabular}

Page 75 


\begin{tabular}{|c|c|c|c|c|c|c|c|c|c|c|}
\hline 0.2488 & 0.1961 & 0.1597 & 0.1307 & 0.1087 & 7 & 8.5 & 0.03 & 3.185 & 2.695 & 2.635 \\
\hline 0.2200 & 0.1600 & 0.1300 & 0.1000 & 0.0900 & 7 & 10.3 & 0.015 & 5 & 3 & 6 \\
\hline 0.2323 & 0.1794 & 0.1496 & 0.1163 & 0.0991 & 7 & 12.6 & 0.03 & 3.285 & 3.005 & 2.645 \\
\hline 0.3333 & 0.2585 & 0.2091 & 0.1635 & 0.1429 & 7 & 19.3 & 0.03 & 4.945 & 4.55 & 3.74 \\
\hline 0.2900 & 0.2300 & 0.1800 & 0.1500 & 0.1300 & 7 & 21.1 & 0.03 & 3 & 4 & \\
\hline 0.3000 & 0.2400 & 0.2000 & 0.1500 & 0.1200 & 7 & 22.8 & 0.03 & 4 & 3 & \\
\hline 0.3500 & 0.2600 & 0.2000 & 0.1600 & 0.1400 & 7 & 24.4 & 0.03 & 3.5 & 3.5 & 4.5 \\
\hline 0.1500 & 0.1500 & 0.1500 & 0.1300 & 0.1300 & 7 & 27.6 & 0.03 & 1 & 0.5 & \\
\hline 0.1135 & 0.0947 & 0.0798 & 0.0658 & 0.0567 & 8 & 2.8 & 0.03 & 1.49 & 1.13 & 0.94 \\
\hline 0.3303 & 0.2601 & 0.2155 & 0.1757 & 0.1512 & 8 & 6.8 & 0.03 & 5.12 & 4.385 & 3.51 \\
\hline 0.3359 & 0.2706 & 0.2243 & 0.1862 & 0.1617 & 8 & 11.1 & 0.03 & 6.01 & 4.55 & 3.265 \\
\hline 0.3260 & 0.2510 & 0.1992 & 0.1600 & 0.1336 & 8 & 15.1 & 0.03 & 4.68 & 4.295 & 3.75 \\
\hline 0.3538 & 0.2742 & 0.2189 & 0.1771 & 0.1500 & 8 & 21.1 & 0.03 & 3.41 & 3.985 & 3.98 \\
\hline 0.3257 & 0.2533 & 0.2081 & 0.1715 & 0.1473 & 8 & 23.6 & 0.03 & 5.36 & 3.56 & 3.62 \\
\hline 0.2603 & 0.2117 & 0.1790 & 0.1686 & 0.1324 & 9 & 1.5 & 0.03 & 4.19 & 3.085 & 2.43 \\
\hline 0.3326 & 0.2603 & 0.2122 & 0.1722 & 0.1475 & 9 & 3.2 & 0.03 & 6.125 & 4.61 & 3.615 \\
\hline 0.3340 & 0.2612 & 0.2149 & 0.1752 & 0.1488 & 9 & 5.9 & 0.03 & 5.73 & 4.615 & 3.64 \\
\hline 0.3700 & 0.2900 & 0.2400 & 0.1700 & 0.1800 & 9 & 9.4 & 0.03 & 8.5 & 3.5 & 4 \\
\hline 0.3600 & 0.2700 & 0.2200 & 0.1700 & 0.1300 & 9 & 12.9 & 0.03 & 5.5 & 3.5 & 4.5 \\
\hline 0.4232 & 0.3274 & 0.2603 & 0.2096 & 0.1783 & 9 & 3.1 & 0.03 & 4.87 & 5.455 & 4.79 \\
\hline 0.3046 & 0.2405 & 0.1975 & 0.1612 & 0.1376 & 9 & 23.2 & 0.03 & 4.29 & 3.935 & 3.205 \\
\hline 0.3496 & 0.2674 & 0.2045 & 0.1576 & 0.1275 & 9 & 27.1 & 0.03 & 3.645 & 3.92 & 4.11 \\
\hline 0.0700 & 0.0700 & 0.0500 & 0.0500 & 0.0500 & 9 & 31.2 & 0.03 & 1 & 1 & 0 \\
\hline 0.2953 & 0.2444 & 0.2087 & 0.1775 & 0.1483 & 10 & 1.3 & 0.03 & 4.33 & 3.385 & 2.545 \\
\hline 0.3686 & 0.3010 & 0.2475 & 0.2042 & 0.1703 & 10 & 6.4 & 0.03 & 4.77 & 3.77 & 3.38 \\
\hline 0.3461 & 0.2709 & 0.2163 & 0.1749 & 0.1410 & 10 & 13.2 & 0.03 & 3.65 & 3.7 & 3.76 \\
\hline 0.4038 & 0.3265 & 0.2651 & 0.2122 & 0.1726 & 10 & 16.4 & 0.03 & 2.905 & 3.4 & 3.865 \\
\hline 0.2829 & 0.2430 & 0.2106 & 0.1810 & 0.1552 & 10 & 17.3 & 0.03 & 2.325 & 1.99 & 1.995 \\
\hline 0.3788 & 0.2993 & 0.2409 & 0.1970 & 0.1631 & 10 & 18.8 & 0.03 & 3.47 & 3.865 & 3.975 \\
\hline 0.2204 & 0.1819 & 0.1559 & 0.1343 & 0.1129 & 10 & 19.7 & 0.03 & 2.955 & 1.795 & 1.925 \\
\hline 0.3490 & 0.2488 & 0.1878 & 0.1511 & 0.1248 & 10 & 20.8 & 0.03 & 2.18 & 3.785 & 5.01 \\
\hline 0.3517 & 0.2703 & 0.2164 & 0.1802 & 0.1512 & 10 & 24.1 & 0.03 & 4.325 & 4.145 & 4.07 \\
\hline 0.1389 & 0.1187 & 0.1043 & 0.0941 & 0.0854 & 11 & 3.9 & 0.03 & 1.495 & 1.085 & 1.01 \\
\hline 0.2887 & 0.2318 & 0.1930 & 0.1605 & 0.1365 & 11 & 7.3 & 0.03 & 5.69 & 3.94 & 2.845 \\
\hline 0.3985 & 0.3172 & 0.2595 & 0.2158 & 0.1793 & 11 & 8.9 & 0.03 & 6.845 & 4.91 & 4.065 \\
\hline 0.3148 & 0.2487 & 0.2035 & 0.1688 & 0.1429 & 11 & 10.6 & 0.03 & 5.255 & 4.085 & 3.305 \\
\hline 0.3061 & 0.2440 & 0.2022 & 0.1716 & 0.1452 & 11 & 16.5 & 0.03 & 4.695 & 3.68 & 3.105 \\
\hline 0.4788 & 0.3661 & 0.2869 & 0.2331 & 0.1904 & 11 & 20.8 & 0.03 & 5.24 & 6.12 & 5.635 \\
\hline 0.3501 & 0.2720 & 0.2166 & 0.1802 & 0.1501 & 11 & 25.4 & 0.03 & 3.83 & 4.325 & 3.905 \\
\hline 0.4799 & 0.3518 & 0.2726 & 0.2168 & 0.1762 & 11 & 27.6 & 0.03 & 3.325 & 5.435 & 6.405 \\
\hline 0.2011 & 0.1517 & 0.1215 & 0.0920 & 0.0752 & 12 & 0.6 & 0.015 & 3.36 & 4.09 & 4.94 \\
\hline 0.6344 & 0.5168 & 0.4157 & 0.3249 & 0.2710 & 12 & 3.4 & 0.03 & 2.29 & 4.745 & 5.88 \\
\hline 0.5114 & 0.4089 & 0.3191 & 0.2406 & 0.1944 & 12 & 9.6 & 0.03 & 1.98 & 3.165 & 5.125 \\
\hline 0.6150 & 0.4940 & 0.3882 & 0.2828 & 0.2300 & 12 & 11.5 & 0.03 & 1.86 & 3.835 & 6.05 \\
\hline 0.4721 & 0.3699 & 0.2956 & 0.2406 & 0.2007 & 12 & 15.3 & 0.03 & 4.36 & 5.345 & 5.11 \\
\hline 0.2745 & 0.2253 & 0.1913 & 0.1629 & 0.1422 & 12 & 21.4 & 0.03 & 4.385 & 3.115 & 2.46 \\
\hline 0.5833 & 0.4290 & 0.3334 & 0.2660 & 0.2239 & 12 & 24.6 & 0.03 & 6.96 & 9.98 & 7.715 \\
\hline 0.1478 & 0.1189 & 0.1016 & 0.0821 & 0.0696 & 12 & 25.8 & 0.03 & 2.38 & 1.58 & 1.445 \\
\hline 0.2318 & 0.1870 & 0.1551 & 0.1335 & 0.1154 & 13 & 4.7 & 0.03 & 3.26 & 2.5 & 2.24 \\
\hline 0.3646 & 0.2807 & 0.2231 & 0.1808 & 0.1512 & 13 & 8.6 & 0.03 & 4.475 & 4.925 & 4.195 \\
\hline 0.4244 & 0.3318 & 0.2685 & 0.2203 & 0.1866 & 13 & 13.4 & 0.03 & 6.63 & 4.96 & 4.63 \\
\hline 0.3450 & 0.2673 & 0.2162 & 0.1774 & 0.1491 & 13 & 15.8 & 0.03 & 5.575 & 4.44 & 3.885 \\
\hline 0.6741 & 0.5103 & 0.3880 & 0.3021 & 0.2455 & 13 & 19.2 & 0.03 & 5.12 & 8.3 & 8.19 \\
\hline 0.4075 & 0.3181 & 0.2505 & 0.2020 & 0.1879 & 13 & 21.6 & 0.03 & 3.575 & 4.275 & 4.47 \\
\hline 0.3948 & 0.3014 & 0.2352 & 0.1884 & 0.1598 & 13 & 21.8 & 0.03 & 1.755 & 4.14 & 4.67 \\
\hline 0.4372 & 0.3423 & 0.2673 & 0.2135 & 0.1810 & 13 & 24.8 & 0.03 & 1.98 & 4.74 & 4.745 \\
\hline
\end{tabular}




\begin{tabular}{|c|c|c|c|}
\hline 1.82 & 1.45 & 1.1 & 3.935 \\
\hline 3 & 3 & 1 & 7.5 \\
\hline 1.49 & 1.665 & 0.86 & 3.455 \\
\hline 2.47 & 2.28 & 1.03 & 5.645 \\
\hline 2.5 & 1.5 & 1 & 5 \\
\hline 2 & 2.5 & 1.5 & 4.5 \\
\hline 3 & 2 & 1 & 5.5 \\
\hline 0 & 1 & 0 & 5 \\
\hline 0.745 & 0.7 & 0.455 & 1.335 \\
\hline 2.23 & 1.99 & 1.225 & 6.06 \\
\hline 2.315 & 1.905 & 1.225 & 6.585 \\
\hline 2.59 & 1.96 & 1.32 & 5.18 \\
\hline 2.765 & 2.09 & 1.355 & 6 \\
\hline 2.26 & 1.83 & 1.21 & 5.865 \\
\hline 1.635 & 0.52 & 1.81 & 5.12 \\
\hline 2.405 & 2 & 1.235 & 5.875 \\
\hline 2.315 & 1.985 & 1.32 & 5.94 \\
\hline 2.5 & 3.5 & -0.5 & 7.5 \\
\hline 2.5 & 2.5 & 2 & 5 \\
\hline 3.355 & 2.535 & 1.565 & 7.415 \\
\hline 2.15 & 1.815 & 1.18 & 5.38 \\
\hline 3.145 & 2.345 & 1.505 & 4.875 \\
\hline 1 & 0 & 0 & 1 \\
\hline 1.785 & 1.56 & 1.46 & 5.915 \\
\hline 2.675 & 2.165 & 1.695 & 7.015 \\
\hline 2.73 & 2.07 & 1.695 & 5.55 \\
\hline 3.07 & 2.645 & 1.98 & 7.13 \\
\hline 1.62 & 1.48 & 1.29 & 6.26 \\
\hline 2.92 & 2.195 & 1.695 & 6.655 \\
\hline 1.3 & 1.08 & 1.07 & 4.145 \\
\hline 3.05 & 1.835 & 1.315 & 4.74 \\
\hline 2.695 & 1.81 & 1.45 & 6.06 \\
\hline 0.72 & 0.51 & 0.435 & 2.77 \\
\hline 1.94 & 1.625 & 1.2 & 5.325 \\
\hline 2.885 & 2.185 & 1.825 & 7.465 \\
\hline 2.26 & 1.735 & 1.295 & 5.645 \\
\hline 2.09 & 1.53 & 1.32 & 5.76 \\
\hline 3.96 & 2.69 & 2.135 & 8.02 \\
\hline 2.77 & 1.82 & 1.505 & 6.005 \\
\hline 3.96 & 2.79 & 2.03 & 7.31 \\
\hline 3.02 & 2.95 & 0.84 & 6.02 \\
\hline 5.055 & 4.54 & 5.39 & 12.05 \\
\hline 4.49 & 3.925 & 2.31 & 8.22 \\
\hline 5.29 & 5.27 & 2.64 & 10 \\
\hline 3.715 & 2.75 & 1.995 & 8.535 \\
\hline 1.7 & 1.42 & 1.035 & 5.61 \\
\hline 4.78 & 3.37 & 2.105 & 9.695 \\
\hline 0.865 & 0.975 & 0.625 & 1.98 \\
\hline 1.595 & 1.08 & 0.905 & 4.27 \\
\hline 2.88 & 2.115 & 1.48 & 6.06 \\
\hline 3.165 & 2.41 & 1.685 & 7.83 \\
\hline 2.555 & 1.94 & 1.415 & 5.955 \\
\hline 6.115 & 4.295 & 2.83 & 10.775 \\
\hline 3.38 & 2.425 & 0.705 & 7.895 \\
\hline 3.31 & 2.34 & 1.43 & 6.49 \\
\hline 3.75 & 2.69 & 1.625 & 7.55 \\
\hline
\end{tabular}

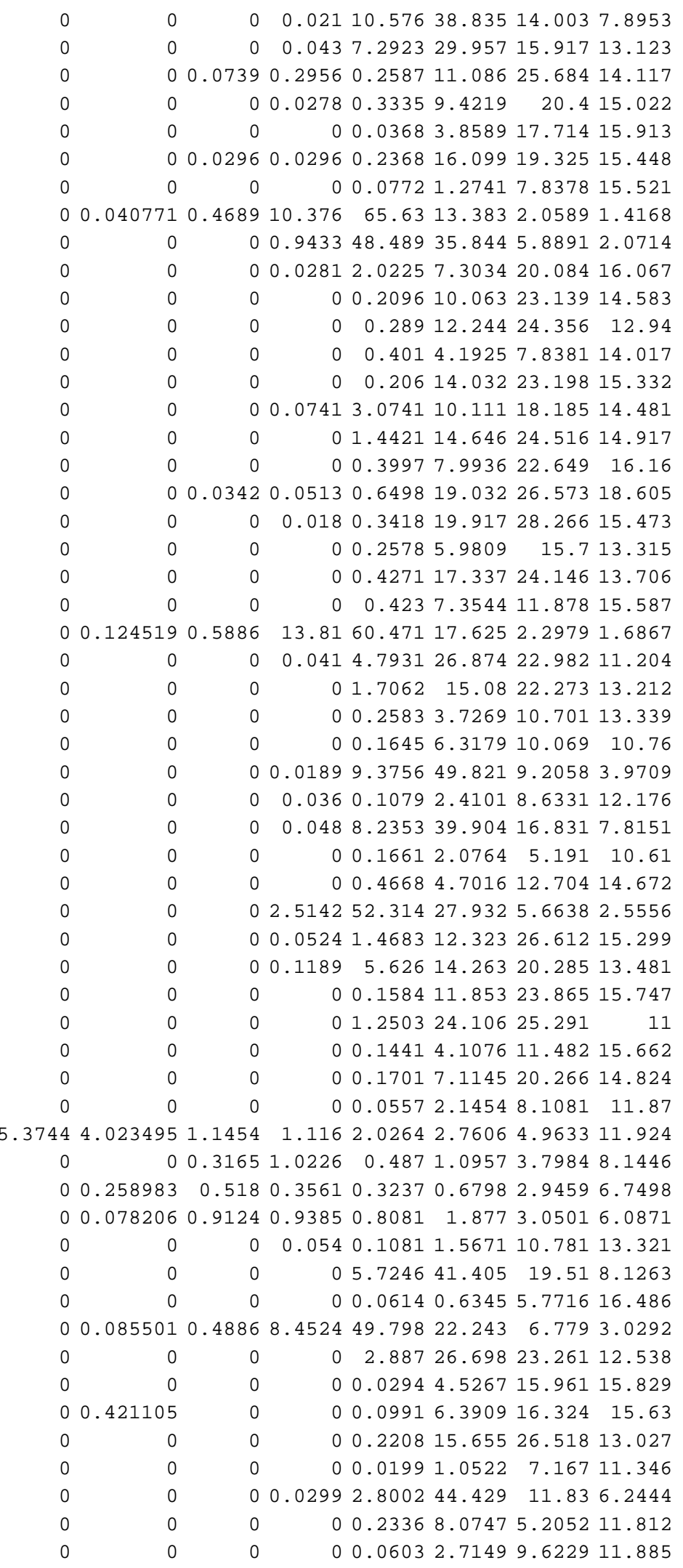

Page 77 
5.66655 .54043 .82673 .04882 .31298 .2738

$\begin{array}{lllllll}4.298 & 8.596 & 4.298 & 4.298 & 1.4327 & 10.745\end{array}$

$\begin{array}{llllll}11.1059 .7746 & 5.5063 & 6.153 & 3.1781 & 12.768\end{array}$

$12.64610 .3956 .86496 .33692 .8627 \quad 15.689$

14.711 .0259 .18785 .51273 .675118 .376

8.87848 .87845 .91897 .39864 .439213 .318 $\begin{array}{llllll}13.514 & 17.375 & 11.583 & 7.722 & 3.861 & 21.236\end{array}$

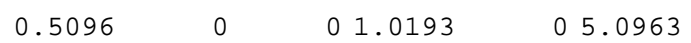
$\begin{array}{lllll}1.4404 & 1.1982 & 0.9496 & 0.8923 & 0.581 .7017\end{array}$ $\begin{array}{llllll}12.317 & 9.8596 & 6.264 & 5.5899 & 3.441 & 17.022\end{array}$ 11.9238 .55616 .06664 .99213 .210217 .256 $\begin{array}{llllll}11.285 & 9.8529 & 6.805 & 5.1498 & 3.4682 & 13.61\end{array}$ $\begin{array}{llllll}14.528 & 14.51 & 10.08 & 7.6194 & 4.9398 & 21.874\end{array}$

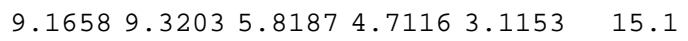
11.426996 .05561 .92596 .703718 .963 $10.388 \quad 8.14565 .41914 .5065 \quad 2.7828 \quad 13.238$ $12.2979 .69896 .1684 \quad 5.28913 .5172 \quad 15.827$ $\begin{array}{lllllll}5.985 & 6.8399 & 4.275 & 5.985 & -0.855 & 12.825\end{array}$ $\begin{array}{lllllll}6.2972 & 8.0964 & 4.498 & 4.498 & 3.5984 & 8.996\end{array}$ 14.06312 .3498 .64916 .53524 .034519 .116 $9.88698 .0528 \quad 5.402 \quad 4.56032 .9648 \quad 13.518$ $12.75613 .375 \quad 10.234 \quad 7.631 \quad 4.8975 \quad 15.864$ $\begin{array}{llllll}1.132 & 0 & 1.132 & 0 & 0 & 1.132\end{array}$ $6.9336 \quad 5.2133 .65633 .19542 .990612 .116$ $8.69267 .79346 .16794 .99193 .9082 \quad 16.175$ $13.65313 .875 \quad 10.074 \quad 7.63846 .2546 \quad 20.48$ $11.18812 .71810 .1028 .70356 .5153 \quad 23.462$ $3.7543 .7634 \quad 3.0562 .79192 .433511 .809$ $13.90314 .29910 .504 \quad 7.89576 .097123 .939$ $\begin{array}{llllll}4.3097 & 4.6218 & 3.1212 & 2.593 & 2.569 & 9.952\end{array}$ $15.71820 .80612 .6667 .6204 \quad 5.461 \quad 19.684$ 13.82113 .5718 .98636 .03534 .834920 .207 1.49881 .39520 .99460 .70450 .60093 .8265 10.337 .45945 .08654 .26063 .146313 .962 9.72668 .05275 .71514 .32843 .615314 .788 10.7848 .72495 .96624 .58033 .418714 .902 $8.07196 .81074 .5843 \quad 3.3562 .8954 \quad 12.634$ $14.701 \quad 13.5369 .51246 .46175 .128519 .265$ 12.25911 .0697 .85155 .15874 .265917 .021 15.14317 .84611 .0347 .77385 .656220 .368 $12.01214 .508 \quad 8.86938 .66374 .9339 \quad 17.68$ $\begin{array}{llllll}11.553 & 14.317 & 12.308 & 11.054 & 6.562 & 29.34\end{array}$ $10.24616 .591 \quad 14.53512 .7067 .478126 .611$ $9.9974 \quad 15.772 \quad 13.7913 .7386 .8822 \quad 26.069$ 14.44213 .80710 .0387 .43045 .390423 .061 5.12424 .04672 .79652 .33591 .70269 .2285 $20.426 \quad 15.799 .78316 .89734 .308219 .842$ $1.9299 \quad 1.7651 .05661 .19090 .76342 .4185$ $\begin{array}{lllllll}6.8738 & 6.1589 & 4.3855 & 2.9695 & 2.4883 & 11.74\end{array}$ 14.47712 .3318 .46566 .21694 .350417 .813 $12.28611 .469 \quad 7.84 \quad 5.96984 .173919 .396$ 9.80358 .57815 .64144 .28353 .124313 .149 $16.478 \quad 16.26 \quad 12.14 \quad 8.52695 .618421 .392$ 6.40166 .69365 .06143 .63131 .055711 .822 $13.81415 .58211 .044 \quad 7.8078 \quad 4.7714 \quad 21.655$ $14.29914 .31411 .3128 .1146 \quad 4.902 \quad 22.775$

$\begin{array}{lrrrrr}0 & 0 & 0 & 0.021 & 10.597 & 49.432 \\ 0 & 0 & 0 & 0.043 & 7.3352 & 37.292 \\ 0 & 0 & 0.0739 & 0.3695 & 0.6282 & 11.715 \\ 0 & 0 & 0 & 0.0278 & 0.3613 & 9.7832 \\ 0 & 0 & 0 & 0 & 0.0368 & 3.8956 \\ 0 & 0 & 0.0296 & 0.0592 & 0.2959 & 16.395 \\ 0 & 0 & 0 & 0 & 0.0772 & 1.3514 \\ 0 & 0.040771 & 0.5096 & 10.886 & 76.516 & 89.899 \\ 0 & 0 & 0 & 0.9433 & 49.433 & 85.277 \\ 0 & 0 & 0 & 0.0281 & 2.0506 & 9.3539 \\ 0 & 0 & 0 & 0 & 0.2096 & 10.273 \\ 0 & 0 & 0 & 0 & 0.289 & 12.533 \\ 0 & 0 & 0 & 0 & 0.401 & 4.5935 \\ 0 & 0 & 0 & 0 & 0.206 & 14.238 \\ 0 & 0 & 0 & 0.0741 & 3.1481 & 13.259 \\ 0 & 0 & 0 & 0 & 1.4421 & 16.088 \\ 0 & 0 & 0 & 0 & 0.3997 & 8.3933 \\ 0 & 0 & 0.0342 & 0.0855 & 0.7353 & 19.767 \\ 0 & 0 & 0 & 0.018 & 0.3598 & 20.277 \\ 0 & 0 & 0 & 0 & 0.2578 & 6.2387 \\ 0 & 0 & 0 & 0 & 0.4271 & 17.764 \\ 0 & 0 & 0 & 0 & 0.423 & 7.7774 \\ 0 & 0.124519 & 0.7132 & 14.523 & 74.994 & 92.619 \\ 0 & 0 & 0 & 0.041 & 4.8341 & 31.708 \\ 0 & 0 & 0 & 0 & 1.7062 & 16.786 \\ 0 & 0 & 0 & 0 & 0.2583 & 3.9852 \\ 0 & 0 & 0 & 0 & 0.1645 & 6.4824 \\ 0 & 0 & 0 & 0.0189 & 9.3945 & 59.215 \\ 0 & 0 & 0 & 0.036 & 0.1439 & 2.554 \\ 0 & 0 & 0 & 0.048 & 8.2833 & 48.187 \\ 0 & 0 & 0 & 0 & 0.1661 & 2.2425 \\ 0 & 0 & 0 & 0 & 0.4668 & 5.1684 \\ 0 & 0 & 0 & 0 & 0.0557 & 2.2012 \\ 0 & 0 & 0 & 2.5142 & 54.828 & 82.76 \\ 0 & 0 & 0 & 0.0524 & 1.5207 & 13.844 \\ 0 & 0 & 0 & 0.1189 & 5.7448 & 20.008 \\ 0 & 0 & 0 & 0 & 0.1584 & 12.012 \\ 0 & 0 & 0 & 1.2503 & 25.356 \\ 0 & 0 & 0 & 0 & 0.1441 & 4.2517 \\ 0 & 0 & 0 & 0 & 0 & 0.2846 \\ 0 & 0 & 0 & 0 & 0 & 0\end{array}$

5.37449 .39794410 .54311 .65913 .68616 .446 $\begin{array}{llllll}0 & 0 & 0.3165 & 1.3392 & 1.8262 & 2.9218\end{array}$ $\begin{array}{llllllll}0 & 0.258983 & 0.777 & 1.1331 & 1.4568 & 2.1366\end{array}$ 00.0782060 .99061 .92912 .73724 .6142

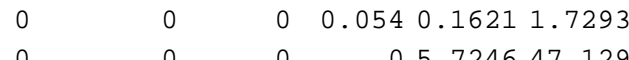

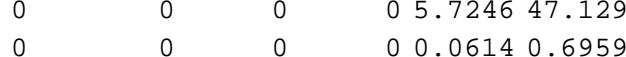
$\begin{array}{llll}0 & 0.085501 & 0.57419 .026558 .82581 .068\end{array}$ $\begin{array}{llllll}0 & 0 & 0 & 0 & 2.887 & 29.585\end{array}$ $\begin{array}{lllll}0 & 0 & 0 & 0 & 0.0294\end{array}$

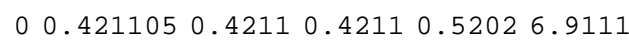
$\begin{array}{llllll}0 & 0 & 0 & 0 & 0.2208 & 15.875\end{array}$ $\begin{array}{lllll}0 & 0 & 0 & 0 & 0.01991 .0721\end{array}$

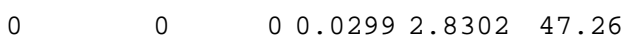

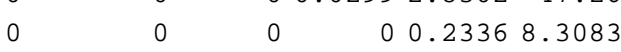
$\begin{array}{lllll}0 & 0 & 0 & 0 & 0.06032 .7753\end{array}$ 
63.43671 .33176 .99782 .53886 .36589 .41391 .726 $53.20966 .332 \quad 70.6379 .22683 .524 \quad 87.82289 .255$ $37.39851 .515 \quad 62.6272 .39577 .90184 .05487 .232$ 30.18345 .20657 .85268 .24675 .11181 .44884 .311 21.6137 .52352 .22363 .24972 .43777 .94981 .624 35.72151 .16960 .04768 .92674 .84582 .24386 .682 $9.1892 \quad 24.7138 .22455 .59867 .18174 .90378 .764$ 91.95893 .37593 .88493 .88493 .88494 .90494 .904 91.16693 .23894 .67895 .87696 .82697 .71898 .298 29.43845 .50657 .82367 .68373 .94779 .53782 .978 33.41247 .99559 .91968 .47574 .54179 .53482 .744 $36.88949 .82961 .11470 .967 \quad 77.772 \quad 82.922 \quad 86.39$ 12.43226 .44940 .97755 .48765 .56773 .18678 .126 $37.43652 .76861 .93471 .25477 .073 \quad 81.784 \quad 84.9$ 31.44445 .92657 .35266 .35272 .40774 .33381 .037 40.60455 .52165 .90874 .05479 .47383 .97986 .762 31.04247 .20259 .49969 .19875 .36680 .65584 .173 $46.34164 .945 \quad 70.93 \quad 77.7782 .045 \quad 88.03 \quad 87.175$ 48.54364 .01670 .31378 .40982 .90887 .40691 .004 $21.93935 .254 \quad 49.31761 .66570 .315 \quad 76.8580 .884$ $41.9155 .61665 .50373 .55578 .95783 .518 \quad 86.482$ 19.65535 .24247 .99961 .37371 .60879 .23984 .136 94.91796 .60497 .73697 .73698 .86898 .86898 .868 54.69165 .89572 .82978 .04281 .69884 .89387 .884 39.05952 .27160 .96468 .75774 .92579 .91783 .825 $14.68628 .02641 .67955 .554 \quad 65.627 \quad 73.266 \quad 79.52$ $\begin{array}{llllll}16.55127 .312 & 38.5 & 51.218 & 61.32 & 70.023 & 76.538\end{array}$ 68.42172 .39276 .14679 .90982 .96585 .75788 .191 $11.18723 .363 \quad 37.26651 .56562 .06869 .96476 .061$ 65.01872 .83377 .14381 .76584 .88687 .47990 .048 7.433618 .04433 .76254 .56867 .23474 .85580 .316 17.87332 .54446 .36559 .93768 .92374 .95879 .793 $88.42490 .97992 .478 \quad 93.873 \quad 94.86895 .573 \quad 96.174$ 40.45655 .75566 .08573 .54578 .63182 .89286 .038 $40.29353 .774 \quad 63.571 .55377 .26881 .59785 .212$ 35.87651 .62462 .40871 .13377 .09981 .67985 .098 $50.64761 .64769 .719 \quad 76.5381 .114 \quad 84.4787 .366$ 15.73431 .39646 .09759 .63269 .14575 .60780 .735 27.55142 .37554 .63465 .70373 .55478 .71382 .979 10.30922 .17937 .32255 .16966 .20273 .97679 .632 $\begin{array}{lllllll}21.41 & 33.333 & 45.345 & 59.853 & 68.722 & 77.386 & 82.32\end{array}$ $6.720214 .86526 .41840 .73553 .04464 .098 \quad 70.66$ 5.082611 .83222 .07838 .66953 .20565 .91173 .389

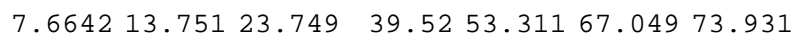
$12.5125 .83140 .273 \quad 54.0864 .11871 .54876 .939$ $66.63974 .766 \quad 79.8983 .93786 .73389 .06990 .772$ 6.467522 .95343 .37959 .16968 .95275 .84980 .158 87.84790 .87692 .80694 .57195 .62796 .81897 .582 $52.84665 .38472 .25778 .41682 .80285 .771 \quad 88.26$ $20.51736 .34650 .823 \quad 63.154 \quad 71.62 \quad 77.83782 .187$ 23.23538 .86551 .15262 .62170 .46176 .43180 .604 42.39355 .42165 .22473 .80279 .44483 .72786 .851 $8.23919 .58536 .06352 .323 \quad 64.463 \quad 72.9978 .608$ 59.0965 .33471 .73678 .42983 .49187 .12288 .178 13.51425 .32539 .13954 .72165 .76673 .57478 .345 12.39824 .28438 .58252 .89664 .20872 .32377 .225
1007.89536 .6968 10013.1237 .1633 $10014.117 \quad 12.14$ 10015.02213 .744 10015.91311 .025 10015.44811 .838 10015.52113 .514 1001.41681 .0193 1002.07141 .8993 10016.06714 .382 10014.58315 .749 $100 \quad 12.94 \quad 12.296$ 10014.01712 .432 $10015.332 \quad 13.8$ 10014.48115 .519 10014.91713 .801 $100 \quad 16.1615 .268$ 10018.60514 .535 10015.4739 .8956 10013.31512 .555 10013.70610 .779 10015.58711 .861 $1001.6867 \quad 1.132$ 10011.2048 .8693 10013.21210 .998 10013.33913 .469 $100 \quad 10.769 .5591$ $1003.9709 \quad 4.386$ 10012.17612 .482 1007.81517 .0948 $100 \quad 10.619 .0532$ 10014.67214 .421 1002.55562 .0652 10015.29914 .919 $10013.481 \quad 13.56$ 10015.74713 .873 $100 \quad 1110.298$ 10015.66212 .587 10014.82410 .856 $100 \quad 11.879 .2644$ 10011.9249 .8678 1008.14465 .5758 1006.74986 .4098 1006.08714 .8488 10013.32111 .781 1008.12637 .2134 10016.48614 .245 $1003.0292 \quad 2.907$ $10012.538 \quad 8.9634$ 10015.82913 .154 $100 \quad 15.63 \quad 16.423$ $\begin{array}{lll}100 & 13.027 \quad 12.31\end{array}$ 10011.34610 .165 $100 \quad 6.2444 \quad 5.3534$ 10011.8125 .8559 10011.8855 .9729
1.2

6.0

2.0

1.3

4.9

3.6

2.0

0.4

0.2

1.7

$-1.2$

0.6

1.6

1.5

$-1.0$

1.1

0.9

4.1

5.6

0.8

2.9

3.7

0.6

2.3

2.2

$-0.1$

1.2

$-0.4$

$-0.3$

0.7

1.6

0.3

0.5

0.4

$-0.1$

1.9

0.7

3.1

4.0

2.6

2.1

2.6

0.3

1.2

1.5

0.9

2.2

0.1

3.6

2.7

$-0.8$

0.7

1.2

0.9

6.0

5.9

Page 79 
$0 \quad 60.85927 .75411 .387$

$0 \quad 50.28 \quad 36.413 \quad 13.306$

032.67349 .76517 .562

$0 \quad 26.4353 .35420 .216$

$0 \quad 18.3558 .15123 .498$

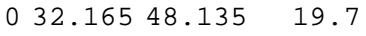

$0 \quad 7.74765 .128 \quad 27.125$

$091.5793 .0568 \quad 5.3640$.

$090.0837 .4012 \quad 2.516$

025.74352 .32621 .932

$029.154 \quad 49.06821 .778$

$032.408 \quad 49.162 \quad 18.431$

010.98960 .19628 .815

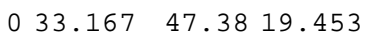

$028.098 \quad 45.72926 .172$

036.09346 .70317 .204

$026.87552 .392 \quad 20.734$

041.45145 .00713 .542

043.34242 .88213 .776

$0 \quad 19.0556 .084 \quad 24.867$

$037.467 \quad 44.853 \quad 17.68$

$0 \quad 17.4759 .76522 .766$

$094.4954 .3735 \quad 1.132$

050.46233 .59215 .946

034.96143 .64521 .394

$\begin{array}{llll}0 & 12.717 & 58.542 & 28.74\end{array}$

014.69953 .03832 .263

066.72718 .29714 .976

$09.598658 .292 \quad 32.11$

061.92124 .87713 .202

06.478466 .37527 .147

015.53557 .83826 .627

087.3828 .00594 .6124

$0 \quad 35.56 \quad 46.214 \quad 18.227$

$\begin{array}{llll}0 & 36.561 & 43.899 & 19.54\end{array}$

031.48548 .99119 .524

$045.99437 .595 \quad 16.411$

$\begin{array}{lll}0 & 13.621 \quad 60.288 & 26.09\end{array}$

023.82253 .53622 .642

08.817463 .11728 .066
$063.43625 .978 \quad 10.58763 .435725 .978 \quad 10.587$

053.20934 .61312 .17853 .209234 .61312 .178

037.39846 .65615 .94637 .398446 .65615 .946 030.18351 .26518 .55230 .183451 .26518 .552 $\begin{array}{lllllll}0 & 21.61 & 56.34 & 22.051 & 21.6097 & 56.34 & 22.051\end{array}$ 035.72146 .52317 .75735 .720646 .52317 .757 09.189265 .71425 .0979 .1891965 .71425 .097 0.0407791 .9172 .94575 .096391 .95472 .94695 .0984 091.1666 .55192 .281791 .16636 .55192 .2817 029.43850 .09820 .46329 .438250 .09820 .463 033.41246 .12220 .46633 .411946 .12220 .466 036.88946 .03317 .07836 .889146 .03317 .078 012.43260 .75526 .81412 .431660 .75526 .814 037.43644 .34918 .21637 .435644 .34918 .216 031.44442 .88925 .66731 .444442 .88925 .667 040.60443 .37516 .02140 .603943 .37516 .021 031.04249 .61419 .34531 .041849 .61419 .345

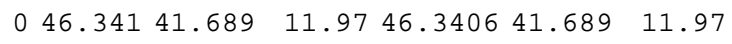
$048.54338 .86312 .594 \quad 48.542638 .86312 .594$

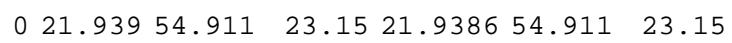
$0 \quad 41.9141 .60816 .48241 .909541 .60816 .482$ 019.65559 .58320 .76119 .655159 .58320 .761 $0.1245294 .793 \quad 3.9506 \quad 1.132 \quad 94.9113 .95561 .1334$ 054.69130 .20315 .10754 .690730 .20315 .107 039.05940 .85820 .08339 .059340 .85820 .083 014.68658 .57926 .73414 .686358 .57926 .734 $016.55153 .47229 .97716 .551553 .472 \quad 29.977$ 068.42117 .33614 .24368 .421117 .33614 .243 011.18758 .77730 .03611 .187158 .77730 .036 $\begin{array}{lllllll}0 & 65.018 & 22.461 & 12.521 & 65.018 & 22.461 & 12.521\end{array}$ 07.433667 .42125 .1457 .4335567 .42125 .145 017.87357 .08625 .04217 .872657 .08625 .042 088.4247 .14884 .427488 .42387 .14884 .4274 040.45642 .43617 .10840 .456242 .43617 .108 040.29341 .30318 .40340 .293241 .30318 .403 035.87645 .80318 .32135 .876545 .80318 .321 $0 \begin{aligned} & 0 \\ & 0\end{aligned} .64733 .823 \quad 15.5350 .647133 .823 \quad 15.53$ 015.73459 .87324 .39315 .733859 .87324 .393

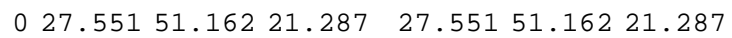
010.30963 .66726 .02410 .309363 .66726 .024

5.3744515 .12254 .61424 .8899 .3979412 .01255 .97722 .61413 .257761 .78324 .959 $06.021355 .17338 .805 \quad 06.720257 .37835 .9026 .7202357 .37835 .902$ 04.540558 .03437 .4260 .258984 .823660 .82934 .0894 .8360960 .98734 .177

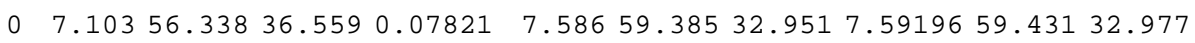
$\begin{array}{lllll}0 & 10.526 & 59.0730 .403 & 0 & 12.5159 .03828 .45212 .510159 .03828 .452\end{array}$ $\begin{array}{llllllll}063.04925 .40611 .545 & 0 & 66.639 & 22.43 & 10.931 & 66.6392 & 22.43 & 10.931\end{array}$ $05.405568 .63225 .962 \quad 06.467569 .38224 .1516 .4674669 .38224 .151$ $086.5999 .90613 .4946 \quad 0.085587 .7618 .97153 .181987 .83628 .97923 .1846$ $048.56636 .42615 .009 \quad 052.84632 .92514 .22952 .845832 .92514 .229$ $0 \quad 17.5858 .62323 .796 \quad 020.51757 .31922 .16320 .517357 .31922 .163$

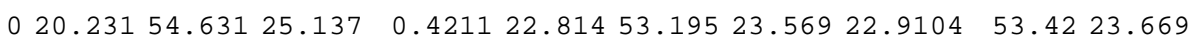
$037.514 \quad 45.08817 .398$ $06.9203 \quad 63.83 \quad 29.25$ 056.91329 .25513 .832 012.55658 .96728 .477 010.62859 .56429 .808 042.39341 .33416 .27342 .393541 .33416 .273 $\begin{array}{llllllll}0 & 8.239 & 64.751 & 27.01 & 8.23903 & 64.751 & 27.01\end{array}$ $0 \quad 59.0928 .03212 .87859 .089528 .03212 .878$

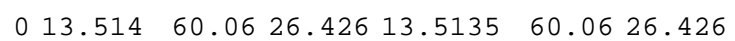
012.39859 .92527 .67712 .398259 .92527 .677

Page 80 


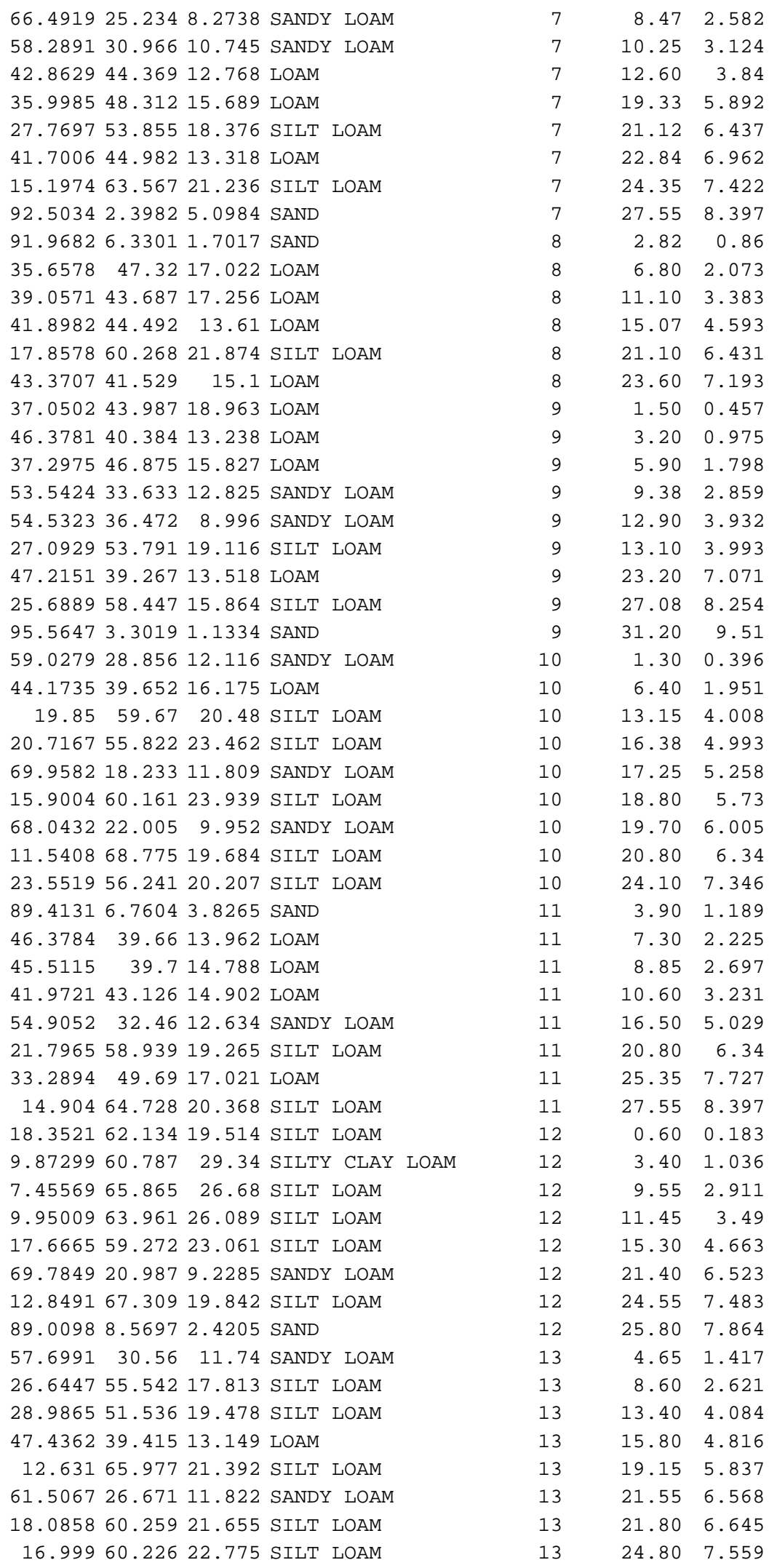

Page 81 
EAST-WEST CROSS-SECTION OF THE ST. ALBANS ARCHEOLOGICAL SITE TERRACE (PLATE A)

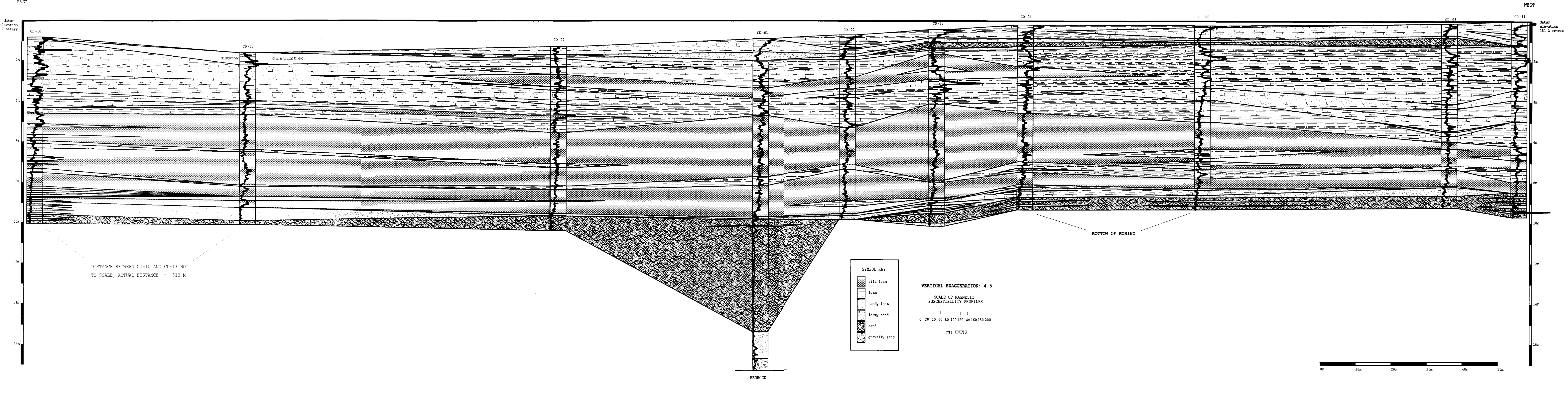




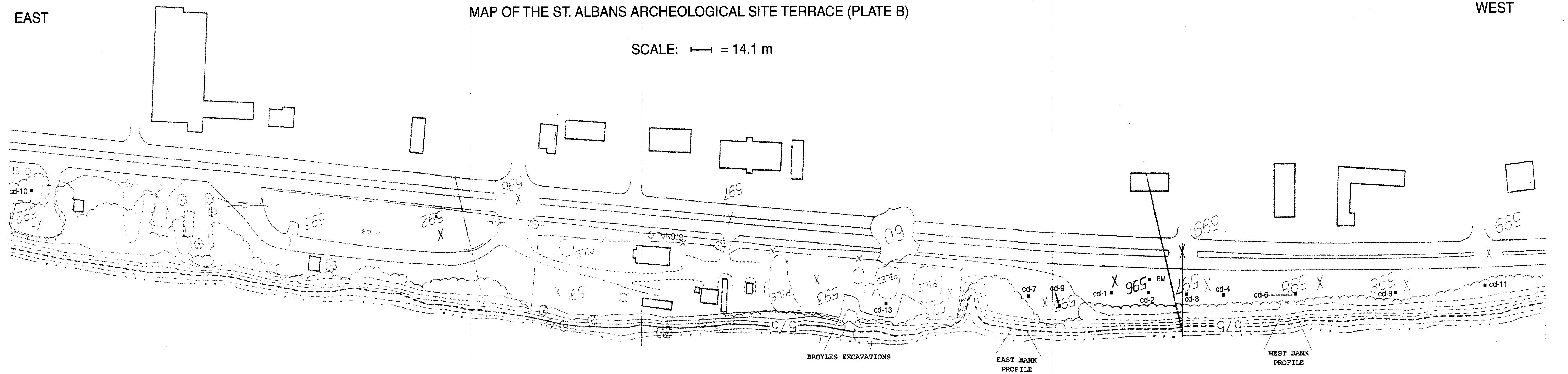

